\title{
Surveillance of infrainguinal autologous vein bypasses
}

Citation for published version (APA):

Idu, M. M. (1998). Surveillance of infrainguinal autologous vein bypasses. [Doctoral Thesis, Maastricht University]. Universiteit Maastricht. https://doi.org/10.26481/dis.19980618mi

Document status and date:

Published: 01/01/1998

DOI:

10.26481/dis.19980618mi

Document Version:

Publisher's PDF, also known as Version of record

\section{Please check the document version of this publication:}

- A submitted manuscript is the version of the article upon submission and before peer-review. There can be important differences between the submitted version and the official published version of record.

People interested in the research are advised to contact the author for the final version of the publication, or visit the DOI to the publisher's website.

- The final author version and the galley proof are versions of the publication after peer review.

- The final published version features the final layout of the paper including the volume, issue and page numbers.

Link to publication

\footnotetext{
General rights rights.

- You may freely distribute the URL identifying the publication in the public portal. please follow below link for the End User Agreement:

www.umlib.nl/taverne-license

Take down policy

If you believe that this document breaches copyright please contact us at:

repository@maastrichtuniversity.nl

providing details and we will investigate your claim.
}

Copyright and moral rights for the publications made accessible in the public portal are retained by the authors and/or other copyright owners and it is a condition of accessing publications that users recognise and abide by the legal requirements associated with these

- Users may download and print one copy of any publication from the public portal for the purpose of private study or research.

- You may not further distribute the material or use it for any profit-making activity or commercial gain

If the publication is distributed under the terms of Article $25 \mathrm{fa}$ of the Dutch Copyright Act, indicated by the "Taverne" license above, 
Surveillance of infrainguinal autologous vein bypasses 
(9. M. Idu, Meastricht, 1998

ISBN 90-901 1584-6 


\title{
Surveillance of infrainguinal autologous vein bypasses
}

\author{
PROEFSCHRIFT
}

ter verknijging van de graad van doctor aan de Universiteit Maastricht, op gezag van de Rector Magnificus, Prof. Dr. A.C. Nieuwenhuijzen Kruseman, volgens het besluit van het College van Decanen, in het openbaar te verdedigen op donderdag 18 juni 1998 om 16.00 uur

door

Mirza M. Idu 


\section{Promotor}

Prof. Dr. P.J.E.H.M. Kitslaar

\section{Co-promotor}

Dr. J. Buth

\section{Beoordelingscommissie}

Prof. Dr. J.M.A. van Engelshoven

Prof. Dr. J.A. Rauwerda (Vrije Universiteit Amsterdam)

Prof. Dr. R.S. Reneman

Prof. Dr. H.J.J. Wellens

Financial support by the Commision of Investigate Medicine of the Dutch National Health Insurance Council (Grant OG-93/037) for the prospective part of the study is gratefully acknowledged.

Financial support by the Netherllands Heart Foundation for the publication of this thesis is gratefully acknowledged. 
Aan: mijnouders

Shantie en Danisha 



\section{CONTENTS}

\section{Introduction}

Chapter 1 Preface and aims of the study

Chapter 2 Postoperative infrainguinal bypass graft surveillance

\section{Retrospective Study}

Chapter 3 Impact of a color-flow duplex surveillance program on graft patency

\section{Prospective Studies}

Chapter 4 Factors influencing the development of vein graft stenoses and their significance for clinical management

Chapter 5 Diagnostic accuracy of several surveillance parameters to detect vein graft stenoses

Chapter 6 Vein graft surveillance: is revision without angiography justified and what criteria should be used? 
Chapter 1

\section{Preface}

$\&$

Aims of the study 


\section{PREFACE}

Femorodistal bypass operations are performed increasingly for the treatment of lower limb ischemia. Introduction of fine suture materials and instrumentation, methods that preserve better the intimal layer of venous grafts, and the use of the in situ technique have contributed to the application of surgical lower limb revascularization in many patients with extensive occlusive disease. Despite an acceptable success rate, $20 \%$ to $30 \%$ of these grafts develop stenotic lesions in the first postoperative year. It is now generally accepted that these stenoses, because of intimal hyperplasia, are the predominant cause of graft failure.

In 1987 color-flow duplex scanning was introduced in the Surgical Department of the Catharina Hospital Eindhoven as a method to visualize peripheral arteries. In earlier studies using gray-scale duplex it was demonstrated that identification of vein graft stenosis was possible and detection and correction of these lesions was successful in preventing graft failure. Color-duplex scanning had not been used for this application before, when in 1989 the results of a pilot study about surveillance using color-flow duplex for the detection of stenosis in femorodistal grafts were published by the Catharina Vascular Surgical group'. Color-duplex appeared to offer several advantages over gray-scale duplex scanning, including improved expediency in performing the examination. The results of a larger retrospective study which started after publication of this first study is presented in chapter three (retrospective part). Although this was a retrospective study the preoperative work-up, the operative procedures, the postoperative duplex examinations (follow-up schedule, technique of color-flow Doppler imaging, sample volume placement and Doppler-angle), the use of the different parameters and patient recond keeping were strictly standardized and constant during the study period. Specific questions conceming vein graft survellance. which still existed following the retrospective part were investigated and described in the prospective part of this thesis.

The prospective part of this study was supported by a Grant from the Commission of Investigative Medicine of the Dutch National Health Insurance Council. This study was performed in three vascular centers with experience in infrainguinal vein graft surveillance (Academic Hospital Maastricht, Catharina Ziekenhuis Eindhoven and St. Antonius Ziekenhuis Nieuwegein). The results of this prospective study are presented in chapters four to seven. Chapter two reviews the literature on various aspects of vein graft surveillance as were known in the literature at the time prior to the final analysis of this study. 


\section{Aims of the study}

At the start of the prospective study in 1993 several subjects for further investigation were defined, on the basis of the retrospective work that had been performed before that time. The questions, that were addressed, in the prospective part of this thesis include:

1. What is the role of clinical and graft factors on the development of vein graft stenosis, and their significance for clinical management?

2. How is the diagnostic accuracy of several surveillance parameters in comparison with angiography?

3. Can non-invasive duplex surveillance parameters be used as revision criteria and so substitute the commonly used angiographic revision criterium?

4. Is the first postoperative duplex examination a reliable criterium to categorize grafts into high and low-risk groups for the development of a vein graft stenosis during follow-up?

5. Is there a pattern in the time of onset of graft stenosis during follow-up that allows adoption of an optimal duplex surveillance program? 


\section{REFERENCE}

1. Disselhof $B$, Buth $J$, Jakimowicz $\mathbb{I}$. Early detection of stenosis of femorodistal grafts. A surwillance study using color-duplex scanning. Eur J Vasc Surg 1989,3:43-48. 
Chapter 2

\section{Postoperative infrainguinal bypass graft surveillance}

Part of this chapter has been published as:

Idu MM, Buth J. Postoperaive infrainguinal bypass grafi surveillance. State of the art. Vasc Surg 1997;31:115-121. 


\section{Introduction}

Autologous vein bypass grafting is considered the best infrainguinal reconstruction for alleviating symptoms of tower limb ischemia. However, there is a high incidence of graft occlusions resulting in patency rates of $30 \%$ to $75 \%$ at five years. ${ }^{1-4}$. While approximately $10 \%$ of grafts fail within the first months, most commonly because of operative technical errors, it has long been assumed that most failures were due to progression of atherosclerosis within the inflow and run-off vessels, and that little could be done to influence this natural course. In the recent years, however, it has become apparent that loss of a bypass because of progression of atherosclerosis tends to occur several years after the procedure and that atherosclerosis can not be considered the most frequent cause of graft occlusion. After the early postoperative period stenotic lesions in the graft and the anastomotic areas are the main cause of graft failure in the first five years after the operation, with $65 \%$ to $75 \%$ occurring within the first postoperative year. ${ }^{5}$ Stenotic lesions are most frequently caused by myointimal hyperplasia, a phenomenon of which the correlation with vein graft occlusion was recognized already in 1973 by Szilagyi. "Nevertheless, it was only at the end of the 1980s that the clinical significance of stenosis development in vein grafts and anastomotic areas were confirmed, because of a more general use of postoperative examination by non-invasive techniques. ${ }^{7,8}$ The pathogenesis of myointimal hyperplasia in vein grafts is essentially unknown, although several factors have been associated with its occurrence, such as smoking, a high fibrinogen concentration, the presence of anticardiolipin antibodies, preexisting fibrosis in the vein graft, and vein graft flow conditions. ${ }^{9.12}$ In addition intraluminal instrumentation may promote myointimal hyperplasia because of endothelial desquamation, subsequent platelet deposition and release of platelet-derived growth factor. ${ }^{1.3}$

\section{The rationale for vein graft surveillance}

Reconstitution of patency in vein grafts after complete occlusion by thrombectomy or thrombolysis results in a disappointing long-term patency of $20 \%$ to $28 \%$. It is generally accepted that the follow-up of patients with infrainguinal vein grafts should be directed towards the identification of failing grafts. ${ }^{14.15}$ At this stage relatively minor procedures can often avert impending graft failure. It has been shown that secondary patency of electively revised grafts is comparable with the primary patency in bypasses without stenoses. ${ }^{.}$Only $1 / 3$ of hemodynamically significant graft stenoses can be diagnosed by the return of ischemic symptoms or decreased pulses at physical examination. ${ }^{16,17}$ In contrast it has been shown that periodic surveillance using intravenous digital subtraction angiography (iv DSA) or non-invasive methods, such as ankle brachial pressure index (ABI) measurements or duplex scanning, are effective in 
identifying graft stenoses. Using these methods stenotic lesions have been found in $25 \%$ to $30 \%$ of vein grafts with the majority identified in the first year ${ }^{0.7 .16,19 \%-20}$

Which bypasses should be systematically followed? There is no significant difference between the incidence of myointimal hyperplasia or valve site fibrosis in insitu, non-reversed translocated, reversed and arm-vein grafts. ${ }^{21.23}$ Although intima hyperplasia in prosthetic bypasses is frequently observed, especially at the site of distal anastomoses, regular non-invasive examination has not been demonstrated successful in recognizing failing grafts. Occlusions without identifiable stenosis are far more frequent with this type of conduit. Moreover, prosthetic graft attrition is an ongoing process, continuing after the first two years. Several reports now have observed this distinction between vein and prosthetic grafts and have concluded that the application of serial non-invasive examination is far less useful in the latter category. ${ }^{24,25}$ The fact that in the United States the Health Care Administration has been reluctant to reimburse for ongoing surveillance of synthetic grafts, whereas it will reimburse for vein graft surveillance, tends to support this conclusion. ${ }^{26}$

Repair of vein graft stenoses has been performed successfully for more than two decades. ${ }^{27,28}$ Patch plasty, excision with direct repair, and implantation of jump grafts at the anastomotic sides are the most common operative methods for revision. The results of PTA seem less durable than those of surgical revision, as combined recurrence and failure rates of $33 \%$ to $50 \%$ were seen. ${ }^{20.33}$ Especially when lesions are longer than $1 \mathrm{~cm}$ poor results can be expected. It should be considered that myointimal hyperplasia occasionally causes a very diffusely diseased graft, which may be impossible to salvage by a revision.

Correction of high-grade stenotic lesions may improve long-term graft patency rates by approximately $15 \% .16,19$ Moreover, it was demonstrated that the probability of graft occlusion in patients followed by an intensive surveillance program using serial duplex examinations was less than one-third of that in patients with conventional follow-up ${ }^{34}$ For these reasons in recent years surveillance programs of femorodistal vein grafts using non-invasive methods have been started in many institutions.

\section{Which surveillance method is best?}

Ankle brachial index (ABI) measurement has been extensively used as an indicator of significant stenosis in grafts and adjacent inflow and run-off arteries. ${ }^{18,35,36} \mathrm{An}$ interval drop of the resting $A B I$ for identifyning impending graft failure has been investigated at different threshold values. Respective decreases of $0.20,0.15$, and 0.10 were evaluated. ${ }^{17,3742}$ However, irrespective the criterion used, the narrow diagnostic range of the $\mathrm{ABI}$ appeared a severe limitation for the identification of graft stenoses. For example, values less than 0.15 are within the biologic and measurement variations, while values greater than 0.20 are more often associated with an occluded graft than 
with a failing bypass. Moreover, several investigators have found that in $50 \%$ to $80 \%$ of cases significant stenoses were missed by serial determination of $\mathrm{ABI}$, and one may conclude that $A B I$ measurements do not provide an accurate indicator. ${ }^{37,38}$ Some studies have suggested that $A B I$ combined with ankle pressure measurements postexercise and at reactive hyperemia following cuff occlusion might be able to improve the diagnostic sensitivity. A draw-back of these stress tests is a low sensitivity and the fact that they can not be applied in all patients."

Despite its limited diagnostic value in detecting stenotic lesions ankle blood pressure measurements will probably remain part of the follow-up examination. Several investigators use $\mathrm{ABI}$ to supplement a duplex surveillance protocol; grafts with evidence of stenoses are being followed at short intervals until a drop in $A B I$ develops. ${ }^{41,42,44}$ It has been suggested that frequent serial $\mathrm{ABl}$ determinations might result a better yield of stenosis detection than the figures noted above..$^{25,45}$

The usefulness of duplex scanning for methodical follow-up of infrainguinal vein grafts has been recognized and several comparative studies demonstrated that duplex scanning is superior to standard follow-up methods to detect graft stenosis. ${ }^{7,17,19,40,46}$ More over, moderate graft stenosis may also be diagnosed and its progression followed to allow timely intervention. The introduction of color-flow duplex systems implied a significant reduction in examination time, compared to the use of conventional grayscale duplex equipment. The entire graft can be traced quickly and stenotic segments can readily be identified by locally increased peak velocities, and poststenotic turbulence characterized by a color-coded random flow pattern. Quantitative pulsed Doppler velocity measurements can be performed as in conventional duplex scanning.

Preliminary results of echo-enhanced Doppler and duplex imaging with ultrasound contrast agents and power-Doppler in native lower limb artery disease have shown that these may improve the quality of the ultrasound scans. ${ }^{47.50}$ The value of these modalities with duplex scanning of infrainguinal vein grafts has to be investigated in greater detail before their ultimate role can be defined.

Non-duplex based surveillance methods, such as impedance measurements have been used for graft surveillance. ${ }^{5 t}$ These methods do not seem to offer a significant advantage over color-flow duplex scanning. Magnetic resonance angiography in its present form is extremely reliable in depicting vascular detail. This method may well replace angiography as a confirmative study in the diagnosis of graft lesions, however, the involved costs makes this method less appropriate for serial use.

\section{Which duplex criteria should be used and which grafts should be repaired?}

For the identification of failing grafts or stenotic lesions low-velocity and high-velocity duplex criteria can be discriminated. The former criterion only requires measurement of the peak systolic velocity (PSV) at a fixed point at mid-graft level (PSV-graft). This 
parameter was particularly easy to determine with gray-scale duplex scanning and most commonly a value of $45 \mathrm{~cm} / \mathrm{s}$ and lower is considered to indicate the graft at risk. It has been observed however, that this criterion had a low sensitivity for focal lesions and that low PSV-graft values frequently were caused by run-off or inflow disease. 22.4 In contrast the specificity of the PSV-graft was found to be high If low velocity criteria are used this is usually in combination with high velocity criteria in order to enhance the diagnostic accuracy of the tests. ${ }^{35,56}$ At present the most common method of collor-flow duplex includes tracing of the entire graft, the identification of sites with Now disturbance and measurement of the PSV at the stenosis. Absolute PSV-values as well as the ratio of the PSV at the stenosis and a normal adjacent arterial segment (PSV-ratio) are used. Threshold values for the PSV-ratio vary in the literature from 1.5 to $3.0,7,19,22,23,42,53$ Another indicator of stenosis is increase of the end-diastolic-velocity (EDV) to greater than $20 \mathrm{~cm} / \mathrm{s}$. At present it is not certain which duplex-derived parameter and which value is most accurate to identify grafts at risk for occlusion. Reports about the criterion for graft revision varies. Some authors revise a graftstenosis when it exceds $50 \%$ DR, while others intervene in stenosis with a DR greater than $70 \%{ }^{25,57-60}$

Not all stenotic lesions require revision. The incidence of bypass occlusions in patients with stenoses ranges from $13 \%$ to $100 \%$, depending on the degree of stenosis and the length of follow-up. ${ }^{34,42}$ It has been observed that stenoses detected early after the operation tended to progress to occlusions more frequently than stenoses detected after 3 months. ${ }^{42,61}$ Stenoses that are identified after 3 months represent more slowly progressing lesions and stenoses identified after 1 year imposed the smallest risk of occlusion. ${ }^{42,60062,63}$

\section{Current issues}

The accuracy of duplex scanning is of prime importance in reporting results of surveillance. Many publications lack a detailed account of the sensitivity and specificity of the used parameters in comparison with angiographic bypass studies. It is likely that there are significant differences in the measurements of velocities between different observers as well as between different duplex scanners. ${ }^{64}$

When a high-grade stenosis is detected it still is common practice to perform a confirmary angiography before intervention. Avoiding confirmary angiograms during follow-up is advantageous because it precludes delay of the revisional procedure and it reduce the overall cost of graft surveillance. The criteria to be used have to be defined and its effectiveness have to be analyzed.

When should a duplex surveillance program start, how long should it be continued, and at what frequency should examinations be performed? It is likely that the development of stenoses in all cases begins at the time of surgery and that stenoses 
reaching the threshold of diagnosis within the early postoperative period are associated with the highest failure rate. It has been suggested that the first duplex scanning can best be performed at the completion of the operation or before discharge as these examinations prompted early revision in approximately $15 \%$ of patients and unrepaired duplex abnormalities required later correction in $32 \%$ to $52 \%{ }^{22,65}$ On the other hand Passman et al ${ }^{5 \%}$ found a poor correlation between the initial duplex scan findings and the subsequent development of a graft stenosis during follow-up.

The vast majority of graft lesions develops within the first twelve months and most authors therefore agree that postdischarge surveillance tests are best performed at 6 weeks and then at the $3 \mathrm{rd}$, 6th, 9th and 12 th month. ${ }^{66}$ Mohan and Corson propose vigorous surveillance for 6 months, while some other investigators prefer indefinite continuation of the assessments at 6 monthly intervals. ${ }^{67.69}$

Is the use of resources for graft surveillance justified from the sake of limb salvage? Recently this issue was addressed in a review of the literature by Golledge et al., who compared the outcomes in surveillance and non-surveillance vein graft groups. ${ }^{70}$ These authors concluded that despite a higher graft patency, surveillance failed to improve the limb salvage rate. One could argue that this study, which was not a formal meta-analysis and considered together claudicants and critical limb ischemia patients, with as a consequence low rates of amputation ( $12 \%$ to $13 \%$ ), did not allow a proper assessment of the influence of graft surveillance on limb salvage. Moreover, the costs of limb loss for the community are quite high and it has been suggested that if limb loss could be prevented in only $2 \%$ of patients a duplex surveillance program would already be cost-effective. ${ }^{66} \mathrm{~A}$ better cost-effectiveness from surveillance may also be considered if the quality of life is compared of patients with relief of claudication because of patent bypass grafts and of patients with intermittent claudication from occluded grafts. Claudication is associated with a considerably impaired quality of life and the expenses to prevent recurrence of this disability may well be justified. ${ }^{71,72}$ Nevertheless, formal cost-effectiveness comparisons of surveillance studies will have to be performed.

In 1992 the ad hoc committee on clinical research recommended a randomized trial comparing the results in patients with intensive surveillance combined with intervention for lesions and patients without interventions. ${ }^{73}$ At this time such a randomized trial would probably be considered unethical on the basis of the currently existing knowledge regarding the benefits of graft surveillance. The only published randomized study had started in 1988 and was published in $1995,{ }^{25}$ Although, this was a rather small study there was a significantly better patency rate in vein grafts in the intensive surveillance group compared to patients with a conventional follow-up schedule. 


\section{REFERENCES}

1. Darling RC, Linton RR. Durability of femoropopliteal reconstruction. Endarterectomy versus vein bypass grafts. Am J Surg 1972;123:472-478.

2. Cranley JJ, Hafner CD. Revascularization of the femoropopliteal arteries using saphenous vein, polytluorothylene, and umbilical vein grafts. Arch Surg 1982;117:1543.

3. Veith FJ, Gupta SK, Ascer E, Scher LA, Samson RH, White-Flores SA, Sprayregen S. Six-ycar prospective multicenter randomized comparison of autologous saphenous vein and expanded polytetrafluoroethylene grafts in infrainguinal anterial recomstructions. J Vase Surg 1986:3:104114

4. Taylor LM, Edwards JM, Porter JM. Present status of reversed vein bypass grafting. Five-year results of a modern series. J Vasc Surg 1990;11:193-206.

5. Brewster DC, La Salle AJ, Robison JG, Strayhorn EC, Darling RC. Fomoro-popliteal graft failures. Clinical consequences and success of secondary reconstructions. Arch Surg 1983;118:1043-1047.

6. Szilagyi DE, Eliot JP, Haglesman JH, Smith RF, Sallolmo CA. Biological fate of autologous vein implants as arterial substitutes. Ann Surg 1973;178:232-246.

7. Grigg MJ, Nicolaides AN, Wolfe JHN. Femorodistal vein bypass graft stenosis. Br $\amalg$ Surg 1988;75:737-740.

8. Bandyk DF, Schmitt DD, Scabrook GR, Adams MB, Towne JB. Monitoring functional patency of in situ saphenous vein bypasses: the impact of a surveillance protocol and elective revision. $J$ Vasc Surg 1989;9:286-296.

9. Panetta TF, Marin ML, Veith FJ,Goldsmith J, Gordon RE, Jones AM, Schwartz ML, Gupta SK, Wengerter KR. Unsuspected preexisting saphenous vein disease. An unrecognized cause of vein bypass failure. J Vasc Surg 1992;15:102-112

10. Chesine NJW, Wolfe JHN, Baradas MA, Chambler AW, Mikhailidis DP. Smoking and plasma fibrinogen, lipoprotein(a) and serotonin are markers for postoperative infrainguinal grafts stenosis. Eur J Vasc Endovasc Surg 1996;11:479-486.

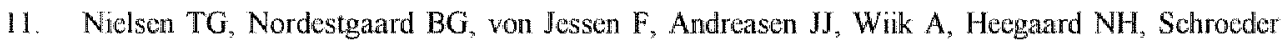
TV. Antibodies to Cardiolipin increase the risk of failure of infrainguinal vein bypasses. Bur I Vase Endovasc Surg 1997,14:177-184.

12. Hofstra L, Tordoir JH, Kitslaar PJ, Hocks AP, Daemen MJ. Enhanced cellular proliferation in intact stenotic lesions derived from human arteriovenous fistulas and peripheral bypass grafts. Docs it correlate with flow parameters? Circulation 1996;94:1283-1290.

13. Davies MG, Hagen PO. Pathobiology of intimal hyperplasia. Br J Surg 1994:81:1254-1269

14. Cohen JR, Mannick JA, Couch NP, Whittemore AD. Recognition and management of impending vein-graft failure. Importance for long-term patency. Arch Surg 1986;121:758-759.

15. Belkin M, Donaldson MC, Whittemore AD, Polak JF, Grassi CJ, Harrington DP, Mannick JA. Observations of the use of thrombolytic agents for thrombotic occlusions of infrainguinal vein grafts. J Vasc Surg 1990;11:289-296.

16. Moody P, Gould DA, Harris PL. Vein graft surveillance improves patency in femoropopliteal bypass. Eur J Vasc Surg, 1990;4:117-121.

17. Disselhoff B, Buth J, Jakimowicz J. Early detection of stenosis of femoro-distal grafts. A surveillance study using colour-duplex scanning. Eur J Vasc Surg 1989;3:43-48.

18. Berkowitz H, Hobbs Ch, Roberts B, Fricdman D, Olcaga J, Ring E. Value of routine vascular laboratory studies to identify veir graft stenoses. Surgery 1989:90:971-979. 
19. Sladen $\mathrm{JG}_{\mathrm{G}}$ Gilimour JL. Vein graft stenosis: characteristics and effect of tratment. Am J Surg $1981,41.549-553$

20. Whittemore AD, Clowes AW, Couch NP, Mannick JA Secondary femoro-popliteal reconstruction. Ain Surg 1981,193:35-42.

21. Harris PL, deCossart LM, Moody $P$, Douglas $H$. How can we detect and manage fibrous strictures within new grafts? Are these more problematic with reversed than in sitw bypass. In: Greenthalgh RM, Jamieson CW, Nicolaides AN, ed. Limb salvage and amputation for vascular disease. London: WB Saunders, 1988,221-231.

22. Bandyk DF, Johnson BL, Gupta AK, Esses GE. Nature and management of duplex abnormalities cncountered during infrainguinal bypass grafting. J Vasc Surg 1996;24:430-438.

23. Chalmers RTA, Haballah JJ, Kresowik TF, Sharp WJ, Synn AY, Miller E, Corson JD. The impact of color duplex surveillance on the outcome of lower limb bypass with segments of arm veins. J Vasc Surg 1994;19:279-288

24. Lalak $\mathrm{N} J$, Hancl $\mathrm{KC}$, Hunt J, Morgan A. Duplex scan surveillance of infrainguinal prosthetic bypass grafts. I Vase Surg 1994;20:637-641.

25. Lundell $A$, Lindblad $B$, Bergqvist $D$, Hansen $F$. Femoropopliteal-crural graft patency is improved by an intensive surveillance program: A prospective randomized study. J Vase Surg 1995,21:2634 .

26. Herzer in discussion. Lundell et al. J Vasc Surg 1995;21:26-34.

27. Breslau RC, DeWeese JA. Successful endophlebectomy of autogenous venous bypass grafts. Am Surg 1965, 162:251-254.

28. McNamara JJ, Darling RC, Linton RR. Segmental stenosis of saphenous vein autografts: Preventable cause of late occlusion in arterial reconstruction. N Engl J Med 1967;277:290-292.

29. Bandyk DF, Bergamini TM, Towne JB, Schmitt DD, Scabrook GR. Durability of vein graft revision: The outcome of secondary procedures. J Vase Surg 1991;13:200-210

30. Harris PL, Moody AP. The management of vein bypass strictures. In: Greenhalgh RM, Hollier LM, ed. The maintenance of arterial reconstruction. London: WB Saunders 199:169-1.79.

31. Perler BA, Osterman FA, Mitchell SE, Burdick JF, Williams GM. Balloon dilatation versus surgical revision of infra-inguinal autogenous wein graft stenosis long-term follow-up. I Cardiovase Surg 1990;31:656-667.

32. Whittemore AD, Donaldson MC, Polak JF, Mannick JA Limitations of balloon angioplasty for wein graft stenosis. IVasc Surg 1991;14:340-345

33. Sanchcz LA, Suggs WD, Marin ML, Panetta TF, Wengerter KR, Veith FI Is percutaneous balloon angioplasty appropriate in the treatment of graft and anastomotic lesions responsible for failing vein bypasses. Am J Surg 1994;168:97-101.

34. \du MM, Blankensteyn JD, de Gier P, Truyen E, Buth J. Impact of a color-flow duplex surveillance progran on infrainguinal vein graft patency. A five-year experience. I Vasc Surg $1993 ; 17: 42-53$.

35. Sumner DS, Standness DE. Hemodynamic studies before and after extended bypass grafts to the tibial and peroneal arteries. Surgery 1979;86:442-452

36. OMara CS, Flim WR, Johnson ND, Bergan JJ, Yao JST. Recognition and surgical management of patent but hemodynamically failed arterial grafts. Aun Surg 1981;193:467-476.

37. Wolfe JHN, Thomas ML, Jamieson CW, Browse NL, Burnand KG, Rutt DL. Early diagnosis of femorodistal graft stenosis. Br J Surg 1987;74:268-270. 
38. Mills JL, Harris JE, Taylor LM, Beckett WC, Porter JM. The importance of routine surveillance of distal bypass grafts with duplex scanning: a study of 379 reversed vein grafts. I Vasc Surg 1990;12:379-389.

39. Bandyk DF, Seabrook GR, Mildenhauer P, Lavin J, Edwards I, Cato R, Trowne JB. Hemodynamics of vein graft stenosis. J Vasc Surg 1988;8:688-695.

40. Barnes RW, Thompson BW, MacDonald CM, Nix ML, Lambeth A, Nix AD, Johnson DW, Wallace BH. Serial noninvasive studies do not herald postoperative falure of femoropopliteal or femorotibial bypass grafts. Ann Surg 1989:2 10:486-494.

41. Green RM, McNamarra J, Ouriel $K$, DeWeese JA. Comparison of infrainguinal gratt surveillance techniques. I Vase Surg 1990;11:207-215.

42. Nielsen TG. Natural history of infrainguinal vein bypass stenoses. Early lesions increase the risk of thrombosis. Eur J Vase Endovase Surg 1996; 12:60-64.

43. Brennan JA, Walsh AKM, Beard JD, Bolia AA, Bell PRF. The role of simple non-invasive testing in infra-inguinal wein graft surveillance. Eur J Vase Surg 1991;5:13-17.

44. Bandyk DF. Postoperative surveillance of infrainguinal bypass. Surg Clin North Am 1990;70:7185.

45. Idu MM, Truyen $E$, Buth J. Surveillance of lower extremity vein grafts. Eur I Vasc Surg $1992 ; 6: 456-462$.

46. Taylor PR, Wolfe JHN, Tyrrell MR, Mansfield AO, Nicolaides AN, Houston RN, Graft stenosis: Justification for 1-year surveillance. Br J Surg 1990;77:1125-1128

47. Langholz $J$, Schlief $R$, Schurmann $R$, Wanke $M$, Heidrich $H$. Contrast enhancentent in leg vessels. Clin Radio 1996,51:3:-34.

48. Langholz J, Wanke M, Petry J. Echo-enhanced ultrasound imaging of leg arteries with Lewovist ${ }^{\text {. }}$. Angiology 1996;47:S37-S49.

49. Steinke $W$, Ries S, Artemis $N$, Schwantz A, Hennerici M. Power Doppler imaging of carotid artery stenosis Comparison with color doppler flow imaging and angiography. Stroke 1997;28:1981-1987.

50. Muller $\mathrm{HR}$, Zweifel $\mathrm{HJ}$. Recent developments in the area of Doppler ultrasound imaging. Ultraschall Med 1997;18:99-100.

51. Wyatt MG, Muir RM, Tennant WG, Scott DJ, Baird RN, Horrocks M. Impedance analysis to identify the "at risk" femonodistal graft. J Vase Surg 1991;13:284-293

52. Sladen JG, Reid JDS, Cooperberg PL, Harrison PB, Maxwell TM, Rings MO, Sanders LD. Color flow duplex screening of infrainguinal grafts combining low and high-xclocity criteria. Am J Surg 1989:158:107-112.

53. Mattos MA, van Bemmelen PS, Hodgson KJ, Ramsey DE, Barkmeicr LD, Sumncr DS, Does correction of stenosis indetified with color duplex sennaing inprove infrainguinal graft patency? J Vasc Surg 1993;17:54-66.

54. Cosman P, Salles-Cunha S, Andros G. Duplex ultrasonography of infrainguinal bypass grafts. J Vasc Technol 1989;13:127-131.

55. Taylor PR, Tyrrell MR, Crofton M, Bassan B, Grigg M, Wolfe JHN, Mansfield AO, Nicolaides AN. Colour flow imaging in the detection of femorodistal graft and native artery stenosis. Improved criteria. Eur J Vase Endovasc Surg 1992;6:232-236.

56. Davies AH, Magee TR, Tennant SGW, Lamont PM, Baird RN, Horrocks. Criteria for identification of the "at-risk" infrainguinal bypass graft. Eur J Vase Endovasc Surg $19948: 315$ 319 . 
57. Buth $\mathrm{J}$, Dissethoff $\mathrm{B}$, Sommeling $\mathrm{C}$, Stam L. Color-flow duplew criteria for grading stenosis in infrainguinal wein grafts. J Vasc Surg 1991;14:716-728.

58. Erickson CA. Towne JB, Seabrook GR, Freischlag JA, Cambria RA. Ongoing vascular laboratory survellance is essential to maximize long-term in-situ saphenous vein bypass patency. J Vasc Surg 1996;23:118-27.

59. Passman MA, Moneta GL, Nehler MR, Taylor LM. Jr. Edwards JM, Yeager RA, Mc Connel DB, Porter JM. Do normal early collor-flow duplex surveillance examination results of infrainguinal vein grafts preclude the need for late graft revision? J Vase Surg 1995;22:476-84.

60. Mills $J L$, Bandyk DF, Gahtan $V$, Esses GE. The origin of infrainguinal vein graft stenosis. A Prospective study based on duplex surweillance. J Vase Surg 1995;21:16-25.

61. Moody P, deCossart LM, Douglas HM, Harris PL. Asymptomatic strictures in femoropopliteal vein grafts. Eur J Vasc Surg 1989;3:389-392.

62. Harris PJ... Vein graft surveillance. All part of the service. Br J Surg 1992;89-97-98.

63. Ho GG. Moll FL, Kuipers MM, van de Pavoordt EDWM, Algra A. Long-term surveillance by duplex scanning of non-reversed infragenicular graft stenosis. Amn Vasc Surg 1995;9:547-553

64. Tessler FN, Kinme-Smith C, Sutherland ML, Schiller VL, Perrella RR, Grant EG. Inter- and intra obderver wariability of Doppler peak velocity measurements: in-vitro study. Ultraound Med Biol 1990;16:653-657.

65. Wilson YG, Davies AH, Currie IC, Morgan M, Baird RN, Lamont PM. The value of predischarge scanming in infrainguinal graft surveillance. Eur J Vasc Endovasc Surg 1996;10:237242.

66. Giannoukas AD, Androulakis AE, Labropoulos N, Wolfe JHN. The role of surveillance after infrainguinal bypass grafting. Eur J Vasc Endovasc Surg 1996,11:279-289.

67. Mohan CR, Hoballah JJ, Schueppert MT, Sharp WJ, Kresowik TF, Miller EV, Corson JD Should all in situ saphenous wein bypasses undergo permanent duplex scanning? Arch Surg $1995 ; 130: 483-488$

68. Sanchez LA, Gupta SK, Veith FJ, Goldsmith J, Lyon RT, Wengerter KR, Panetia TF, Marin ML, Cynamon J, Berdejo. A ten-year experience with one hundred fifty failing or threatened vein and polytetrafluoroethylene arterial bypass grafts. J Vase Surg 1991;14:729-738

69. Dunlop P, Hartshome T, Bolia A, Bell PRF, London NJM. The long-term outcome of infainguinal vein graft surveillance. Eur J Vasc Endovasc 1995; 10:352-355.

70. Golledge J, Beattic DK, Grecnhalgh RM, Davies AH. Have the results of infrainguinal bypass imptroved with the widlespread utilisation of postoperative surveillance? Eur J Vase Endovasc Surg $1996 ; 11: 3848-392$

71. Gibbons GW, Burgess AM, Guadagnoli E, Pamposelli FB Jr, Freeman DV, Campbell DR, Miller A, Marcaccio EJ Jr, Nordberg P, LoGerfo FW. Return to will-being and function after infrainguinal revascularization. J Vase Surg 1995,21:35-45.

72. Curric $1 \mathrm{C}$, Wilson YG, Baird $\mathrm{RN}$, Lamont PM. Treatment of intermittent claudication. The impact on quality of life. Eur J Vase Endovase Surg 1995;10:356-361.

73. Bandyk DF, Sumner DS. Thicle BL, Yao JS. Study for surveillance of infrainguinal arterial bypass. J Vasc Surg 1992;15:899-900. 
Chapter 3

\section{Impact of a color-flow duplex surveillance program on infrainguinal vein graft patency.}

A five-year experience

Idu MM, Blankensteijn JD, de Gier P, Truyen E, Buth J. Impact of a color-flow duplex surveillance program on infrainguinal vein graft patency. A five-year experience.

J Vasc Surg 1993; 17:42-53. 


\section{INTRODUCTION}

One reason for follow-up of patients with infrainguinal bypass procedures is to identify falling vein grafts because stenotic lesions develop relatively frequently in these grafts and their anastomotic areas., Because the long-term patency rates of grafts after thrombectomy and thrombolysis ranges from 19 to $28 \%$, treatment of a failing graft by use of a relatively minor revision is considered advantageous. Because most stenotic graft lesions consist of myointimal hyperplasia and because most are frequently diagnosed within the first 12 to 18 months, a practical surveillance program should concentrate on this initial period. Progression of atherosclerosis in inflow or outflow segments may be the cause of graft failure after longer follow-up periods. "The ability of duplex scanning and more recently color-flow duplex scanning compared with conventional clinical follow-up examination, including ankle pressure measurements, to identify developing preocclusive lesions has lead several investigators to recommend serial duplex or color-flow duplex examinations as the surveillance method of choice ${ }^{3,6-12}$ However, several questions with respect to the application of these advanced screening techniques have remained unanswered. The natural course of stenotic lesions has not been completely clarified in that the proportion of untreated stenoses that become occluded is unknown. ${ }^{13}$ Do all stenoses require revision or is a selective repair more advisable? Are revision procedures more frequently performed when advanced surveillance techniques are used? Finally, do the patency rates of vein grafts that undergo a comprehensiwe surveillance program that may result in timely revision improve significantly compared with the patency rates of vein grafts that undergo conventional follow-up?

In this report we detail our experience with the use of color-flow duplex in the follow-up of infrainguinal vein grafts obtained during a 5 year period. Development of stenotic lesions, progression to occlusion (whether or not a secondary intervention has been performed), and the rates of restenosis were the subject of this study. In addition, the contribution of color-flow duplex surveillance to graft patency relative to other factors was evaluated with use of a multivariate analysis.

\section{PATIENTS AND METHODS}

Two hundred one autologous vein bypass grafts of the infrainguinal arteries were studied; 13 instances of graft occlusion at 30 days after the operation, were not considered for analysis. The operations were performed between September 1986 and May 1991, although the follow-up of this study ended at December 1991. The procedures were carried out in 187 patients, of which $129(69 \%)$ were men and 58 $(31 \%)$ were women. Diabetes mellitus was present in $48(26 \%)$ of all patients. Limb- 
threatening ischemia was the indication for the bypass procedure in $128(64 \%)$ cases: 53 procedures were performed for tissue necrosis and 75 for rest pain. Incapacitating claudication was the preoperative symptom in 68 patients $(34 \%)$ and popliteal aneurysm in five $(2 \%)$. Forty procedures were repeat operations in which a previous revascularization to the popliteal or crural arteries in the same limb had been performed.

Follow-up of 160 grafts included color-flow duplex scanning every 3 months during the first postoperative year and every 6 months during the second year. Postoperative review in 41 grafts comprised only conventional clinical follow-up (i.e. the recording of symptoms, peripheral pulse assessment and the determination of the ankle blood pressure index $[\mathrm{ABI}]$ ). These patients visited the outpatient clinic at similar intervals; color-flow duplex was not used at any time during follow-up. The first category of graft recipients was the "color-flow surveillance group" and the second the "clinical follow-up group". Follow-up examinations were performed either by a senior vascular surgeon or by a vascular surgical fellow under supervision by the senior surgeon. The follow-up protocols in these two patient categories were uneven because some members of the vascular surgical group adhered to an established follow-up scheme and relied on clinical parameters during the first period of this study. The vascular surgical group was organized so that the same vascular surgeon performed the initial examination and postoperative follow-up examinations on the same patient. However, the operation was performed by the surgeon who was on duty according to the patient"s number on the waiting list. Thus the structure of the vascular practice accounted for sufficient randomization of operating surgeons between the two follow-up categories to preclude any bias from different operators. Therefore a comparison of the color-flow surveillance group with the clinical follow-up group seemed acceptable.

After the second year all patients were seen on a yearly basis in the outpatient clinic to record the patency status of the bypass graft with use of clinical assessment and $A B I$ reading so that the necessity of additional intervention could be determined.

\section{Bypass procedures}

A variety of techniques were used to perform the bypass procedures. In situ saphenous vein grafts were used when the ipsillateral saphenous vein was available and suitable for use. Ectopic veins were either reversed or non-reversed depending on the vein taper and the optimal size match between vein grafts and inflow and recipient arteries. Small distal or fibrotic segments were replaced by extension or interposition with a segment of arm-vein or greater or smaller saphenous vein. Sites of origin for the bypasses comprised the common femoral in $127(63 \%)$, the superficial femoral artery in 40 $(20 \%)$, the deep femoral artery in $8(4 \%)$ and the popliteal arteries in $26(13 \%)$ patients. The distal recipient arteries included the proximal popliteal in 17 patients 
$(8.5 \%)$, the distal popliteal in $75(37 \%)$ and one of the crural arteries in $102(54 \%)$. Although scientific proof of efficacy is lacking, postoperative anticoagulation by coumarin derivates was begun in all patients, in accord with traditional treatment in the Netherlands, and was continued until contra-indications occurred. Treatment was usually discontinued because of patient refusal to take this medication and not because of adverse effects or graft occlusion.

\section{Color-flow duplex examination}

Our technique of color-flow duplex examination has been described previously, and only a few points will be summarized. ${ }^{12}$ For this study a Philips-Quantum I color-flow duplex scanner (Philips Medical Systems, Inc., Shelton, Conn.) was used. Moving red cells in the vessels generate Doppler shift frequencies. Direction and velocity dependent color-coded flow is displayed, with red for flow in one direction and blue for the reverse. The higher the Doppler shift frequency, the whiter the color is depicted. Stationary tissues are indicated in gray-scale, which provides a sharp delineation of the vessel wall when the color-flow image is superimposed. The graft was examined from the groin down the entire length to below the distal anastomosis and the first centimeters of the recipient artery. Color images were examined for the presence of biphasic flow, wall irregularities, stenotic decrease of color saturation and poststenotic turbulence (i.e., color bruits). After the graft was imaged, midstream pulsed Doppler velocity spectral signals were recorded from diseased and normal vessel segments. The following parameters were evaluated: (1) the percent diameter reduction (DR) measured by color-flow image at the stenosis and at a nearby normal graft segment, (2) the peak systolic velocity (PSV) at a normal mid-thigh graft segment, (3) the PSV-index (i.e., the ratio of the PSV at the normal mid-thigh graft and the maximum PSV at a stenotic lesion or, in normal grafts, at the narrowest point of the below-knee graft), and (4) the end-diastolic velocity (EDV). Values of the PSVindex in normal grafts approximate 1.00 ; lower values indicate a stenosis. In an earlier study from our institution it was demonstrated that a threshold value of 0.65 was a good discriminator of normal and stenotic bypass grafts. ${ }^{12}$ The presence of a stenotic lesion is determined on the basis of these parameters, whereas its severity was estimated. Because the diagnostic value of these parameters was reported earlier" only PSVindex data will be analyzed in the present study.

\section{Angiography}

In a graft, in which a stenosis of $30 \%$ or greater or an occlusion was suspected on the basis of findings with color-flow duplex examination or on the basis of clinical criteria, intraarterial digital subtraction angiography (DSA) was requested. Accurate assessment of the diameter ratio of stenotic and normal graft sites was facilitated by multiple projections as well as magnified views. A run-off resistance score was 
determined for all grafts in accord with the Ad Hoc Committee on Reporting Standards of the Society for Vascular Surgery and the International Society for Cardiovasculat Surgery. ${ }^{14}$ Preoperative and intraoperative angiograms as well as postoperative DSA studies were reviewed for this purpose. The films that showed most detail of nun-off and foot artery anatomy were used to assess the run-off resistance score.

\section{Data analysis}

Cumulative primary graft patency as defined by the Ad Hoc Committee on Reporting Standards was determined by the life table method ${ }^{14}$ In addition the assisted primary graft patency, in which the revision of a stenotic but open graft is not considered an endpoint of patency, was determined. ${ }^{15}$ Group comparisons for statistical differences in graft patency were performed with use of the logrank test. The Fisher exact test was used for paired comparisons of discrete data in different groups. Comparison of continuous wariables in groups was performed with the Mann-Whitney test. Univariate comparison of patency rates in groups with color-flow surveillance and clinical followup was performed for multiple risk factors and bypass characteristics. Twelve variables were selected because of significant group differences at univariate comparison on clinical relevance, and they were subjected to a multiple regression analysis with a Cox proportional hazard model to examine independent associations. ${ }^{16}$ In this analysis the relative risk indicates the probability of graft occlusion; values greater than 1.0 indicate an increased risk and values between 0 and 1.0 indicate a decreased risk. Only when $p-$ values are less than 0.05 did the relative risk have statistical significance.

\section{RESULTS}

\section{Variables}

The median duration of follow-up until death, graft occlusion or the last visit to the outpatient clinic was 21 months (range 1 to 63 months). There were no marked differences between the patient groups that underwent color-flow surveillance and clinical follow-up with respect to sex, risk factors, $A B 1$, run-off resistance score and graft characteristics (Table I). In patients who underwent color-flow surveillance the median age was 68 years (range 34 to 92), and in patients who underwent clinical follow-up the median age was 70 years (range 54 to 86 ). 
Table 1. Sex, risk factors and graft characieristics in groups with color-flow duplex surveillance and clinical follow-up.

Sex

Male

Female

Presenting symptoms

Tissue loss $\mathrm{G}$ or $\mathrm{U}$

Rest pain

Claudication

Aneurysm

Associated diseases and risk factors

Diabetes mellitus

Hypertension

Smoking

Hypercholesterolemia

History of other vascular disease

Preoperative ABI $<0.50$

SVS/LCVS run-off score $>2.0$

Graft

Provious ipsilateral infrainguinal recon.

Other than in situ wein graft

Poplitcal proximall anastomosis

Crural distal anastomosis

Venovenous anastomosis

Size of graft $<3.5 \mathrm{~mm}$
$102(68)$

48 (32)

27 (73)

$10(27)$

$44(27)$

$59(37)$

9 (22)

$54(34)$

$16(39)$

14 (34)

3 (2)

1 (2)

$42(26)$

46 (29)

8 (19)

$106(68)$

$16(39)$

$30(75)$

43 (29)

$8(22)$

$102(63)$

28 (68)

$99(64)$

$20(51)$

$119(74)$

$26(63)$

35 (22)

5 (112)

$61(38)$

$18(44)$

10 (6)

$3(7)$

$90(56)$

$19(46)$

$26(16)$

$6(15)$

$70(44)$

Percontage of sex telate to number of patients. Other percentages relate to number of grafts. $G$ is gangrene; $U$ is ulceration; SVS/ISCVS is Society for Vascular Surgery / International Society for Cardiovascular Surgery. 


\section{Identification of stenoses}

During follow-up examination stenoses were identified in $58(29 \%)$ wein grats. Simultaneous stenoses of lesser severity remote from the principal stenosis were fomd in 14 grafts. For the purpose of this report only the principal stenosis was contsidered. Thirty-four of these stenoses were focal (stenosis length $\leq 2 \mathrm{~cm}$ ), 15 were intemediats (stenosis length 2 to $4 \mathrm{~cm}$ ) and 9 reflected a more diffuse diseased vein graft (stenosis length $>4 \mathrm{~cm}$ ). The location of the stenosis was in the inflow artery in 8 grafts, at the proximal anastomosis in 14, in the body of the graft above-knee in 18, and below-knee in 12, at the distal anastomosis in 4 , and within the first centimeters of the rum-off vessels in 2 grafts. The time of first occurrence was within the first 3 months in 12 grafts, between 3 and 6 months in 16 , from 6 to 12 months in 21 , between 12 and 18 in 2 , and after 18 months in 7 grafts. The latest occurrence was 34 months after the bypass procedure.

The incidence of graft stenoses in the color-flow surveillance group was $32 \%$ (52 grafts), which was higher than the incidence of graft stenoses in the clinical follow-up group. In this latter group stenotic lesions were diagnosed in three grafts ( $7 \%$ ) before occlusion $(p<0,001)$. In three additional grafts in the group that underwent clinical follow-up, a stenosis was identified after thrombolysis.

Return of clinical symptoms, decrease of ABI, and the level of the PSV-index were correlated with the presence of graft stenoses. Clinical symptoms identified only $19(33 \%)$ of the grafts with stenotic lesions. In 17 grafts (8\%) reliable ankle pressure measurements were not possible due to incompressible crural vessels. No adequate ankle pressure data at different points of follow-up were available in 8 other patients. The ABI was a poor indicator of stenoses. A significant drop (>0.15) in ABI between early postoperative measurements and values at the time of stenosis identification or at the last follow-up was observed in only $19(38 \%)$ grafts with a stenotic lesion, whereas normal grafts were associated with a change in $\mathrm{ABI}$ of less than 0.16 in $110(87 \%)$. The PSV-index provided a good discrimination between stenotic and normal bypasses (Figure 1). Values lower than 0.65 were associated with stenotic lesions in $47(90 \%)$, whereas higher values indicated a normal graft in $104(96 \%)$. We conclude that symptoms and a change in ABI are poor indicators of stenoses, whereas the PSV-index is a highly accurate discriminator. 
Figure 1. Correlation of PSV-index ini vein grafts with and without graft stenosis. Mean PSV-index is $0.41 \pm 0.22$ (SD) for stenotic grafts and $0.97 \pm 0.24$ (SD) for normal grafts, $p<0.001$.

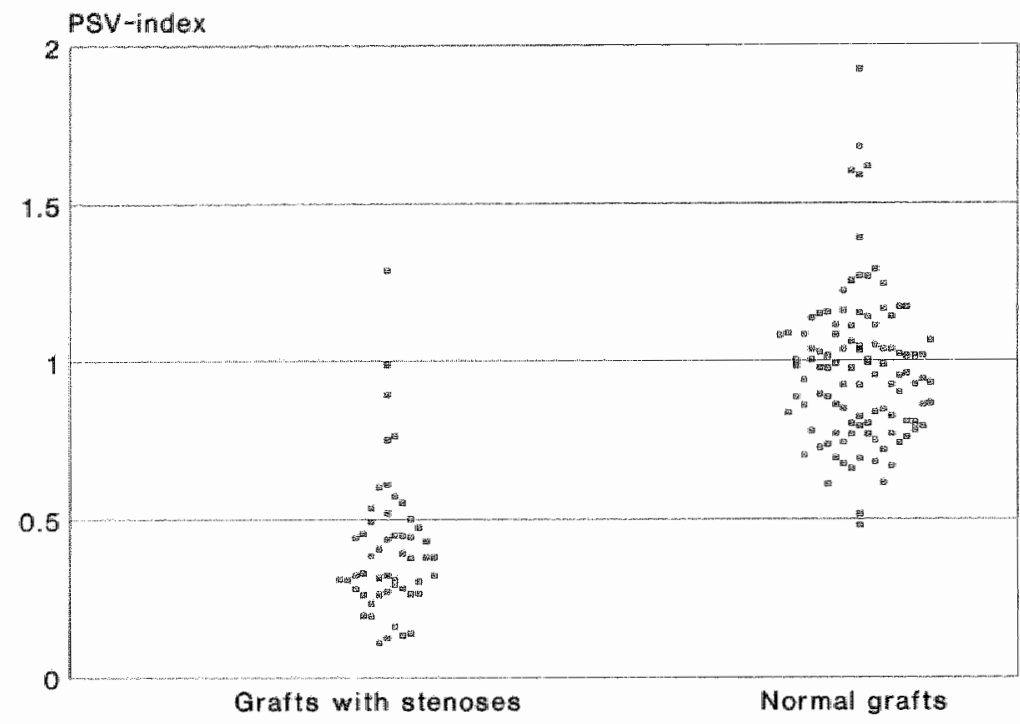

\section{Treatment of stenoses}

Forty of the 58 grafts with stenoses underwent repeat intervention. Vein patch angioplasty was used in 22 grafts, balloon dilatation was used in 11, segmental graft replacement was used in 6 , and a Simpson atherotome (Devices for Vascular Intervention, Inc., Redwood City, Calif.) was used to remove a thickened valve cusp in 1 graft. The reason that reintervention was not performed in 18 grafts was the patients refusal of additional procedures in 3 cases, graft occlusion when waiting for admission in 4 , and doctor choice in 11 cases. In this latter category eight stenoses had less than $50 \%$ DR. In grafts that underwent color-flow surveillance $34(21 \%)$ repeat interventions were performed compared with three $(7 \%)$ revisions on a patent graft in the group with clinical follow-up $(p=0.03)$. In this latter category three additional grafts were treated by thrombolytic therapy followed by a revisional procedure.

The incidence of permanent graft occlusions relative to the diameter reduction as classified by intraaterial DSA and relative to whether or not a repeat graft intervention had been performed is represented in Table II. No repeat procedures were performed in grafts with $30 \%$ to $49 \%$ DR, and no graft failures were observed in this group. Grafts with stenoses of $50 \%$ to $69 \%$ occluded more often if no revision was performed. For grafts with greater than $69 \%$ stenosis the difference in occlusion rate between revised and non-revised lesions is highly significant. There were no differences between grafts 
with different degrees of stenosis when a repeat procedure had been performed. In the non-revised bypasses the occlusion rate was higher in lesions of $50 \%$ or greater DR compared with $30 \%$ to $49 \%$ DR.

A third intervention for graft stenoses was required in $10(25 \%)$ bypass grafts; eight grafts were for recurrent stenoses, and two were for new lesions at sites in remote from the earlier lesion. More than two revisions were performed in three bypass grafts, with a maximum of five repeat reinterventions in one graft. There was no correlation between the incidence of recurrent stenoses and a specific type of revision of the initial lesion.

Table II. Stenotic grafts and incidence of graft occlusions relative to diameter reduction and graft revision.

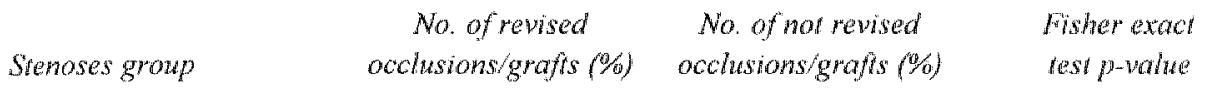

\begin{tabular}{|c|c|c|c|}
\hline group $1(30 \%$ to $49 \% \mathrm{DR})$ & $-1-\quad(-)$ & -18 & NS \\
\hline group $2(50 \%$ to $69 \% \mathrm{DR})$ & $1 / 11 \quad(9)$ & $4 / 7 \quad(57)$ & 0.047 \\
\hline group $3(70 \%$ to $99 \%$ DR) & $3 / 29(10)$ & $3 / 3(100)$ & 0.004 \\
\hline
\end{tabular}

In revised grafts there were no significant group differences in the frequency of occlusions. In grafts not revised the difference was significant between groups 1 and 3 (Fisher exact $p=0.006$ ) and between groups 1 and 2 (Fisher exact $p=0.02$ ), but not between groups 2 and 3. NS, Not significant.

\section{Long term results}

Primary and assisted primary patency rates relative to the type of follow-up, (i.e. for grafts that underwent color-flow surveillance and grafts that underwent clinical followup) are shown in life table format in Figures 2 and 3 and Table III. Color-flow surveillance is associated with a primary patency that is not different from that in grafts that underwent clinical follow-up. In contrast, in grafts that underwent colorflow surveillance the assisted primary patency is significantly higher than in grafts that underwent clinical follow-up ( $91 \%$ and $72 \%$ at 3 years, respectively).

The limb salvage rate was assessed for both follow-up groups. At 5 years the cumulative limb salvage rate was $99 \%$ in the color-flow surveillance group compared with $92 \%$ in grafts in the clinical follow-up group. This difference was significant at a $p$-value of 0.004 . The high overall salvage rate of $97 \%$ can be explained by the fact that first month graft failures were not taken into account. 
To account for any simultaneous effects of variables reported to influence late patency in the total series after vein grafting, 12 selected variables were subjected to assisted primary patency analysis, logrank analysis, and risk estimate from Cox analysis. Improved assisted primary patency was strongly related to color-flow surveillance as an independent variable (Table IV). The relative risk was 0.27 , which means that the risk of occlusion for a graft monitored with color-flow duplex scanning is astimated less than one-third of that for grafts that undergo clinical follow-up. There were no interactions between the other covariates in the model. No other factors had a significant influence on the risk of graft failure. We conclude that the yield of stenosis detection with serial color-flow duplex screening resulted in an optimal use of repeat interventions, whereas use of clinical parameters ultimately resulted in a higher percentage of graft thrombosis because stenotic lesions are missed.

Figure 2. Cumulative primary patency rates in grafts that undergo color-flow (CF) surveillance and in grafts that undergo clinical (CL) follow-up.

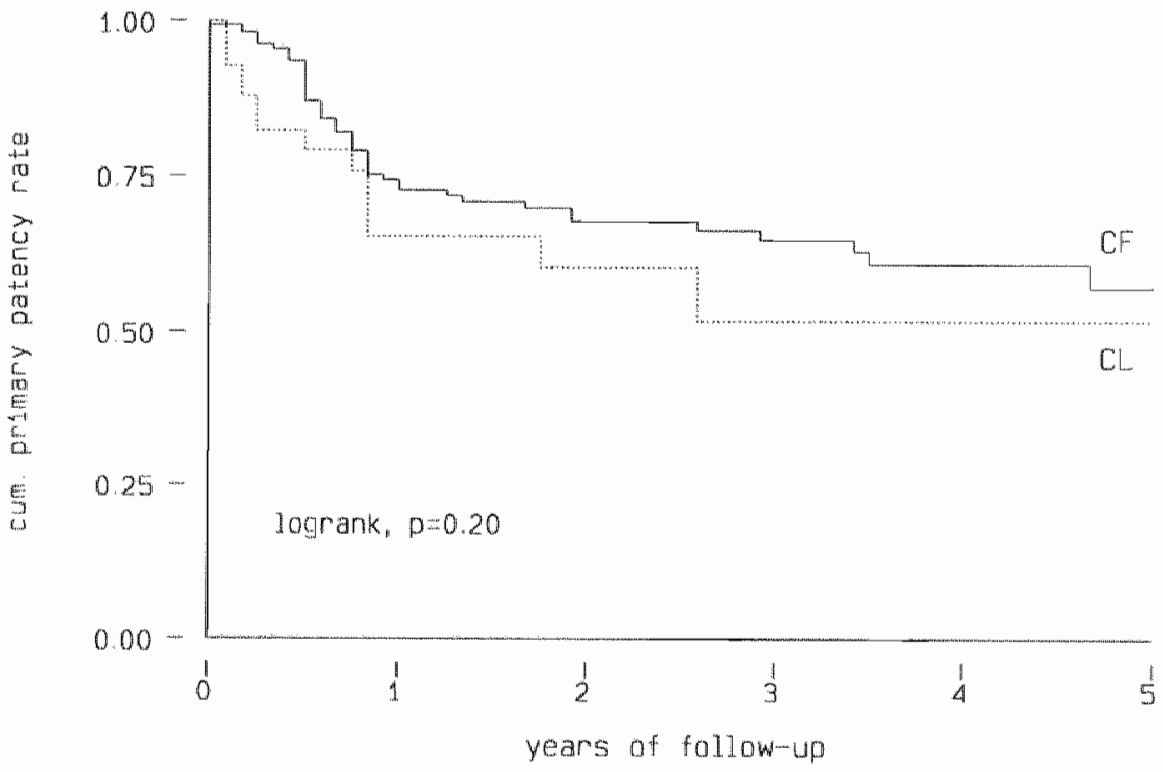


Figure 3. Cumulative assisted primary patency rates in grafts that undergo color-flow (CF) surveillance and in grafts that undergo clinical (CL) follow-up.

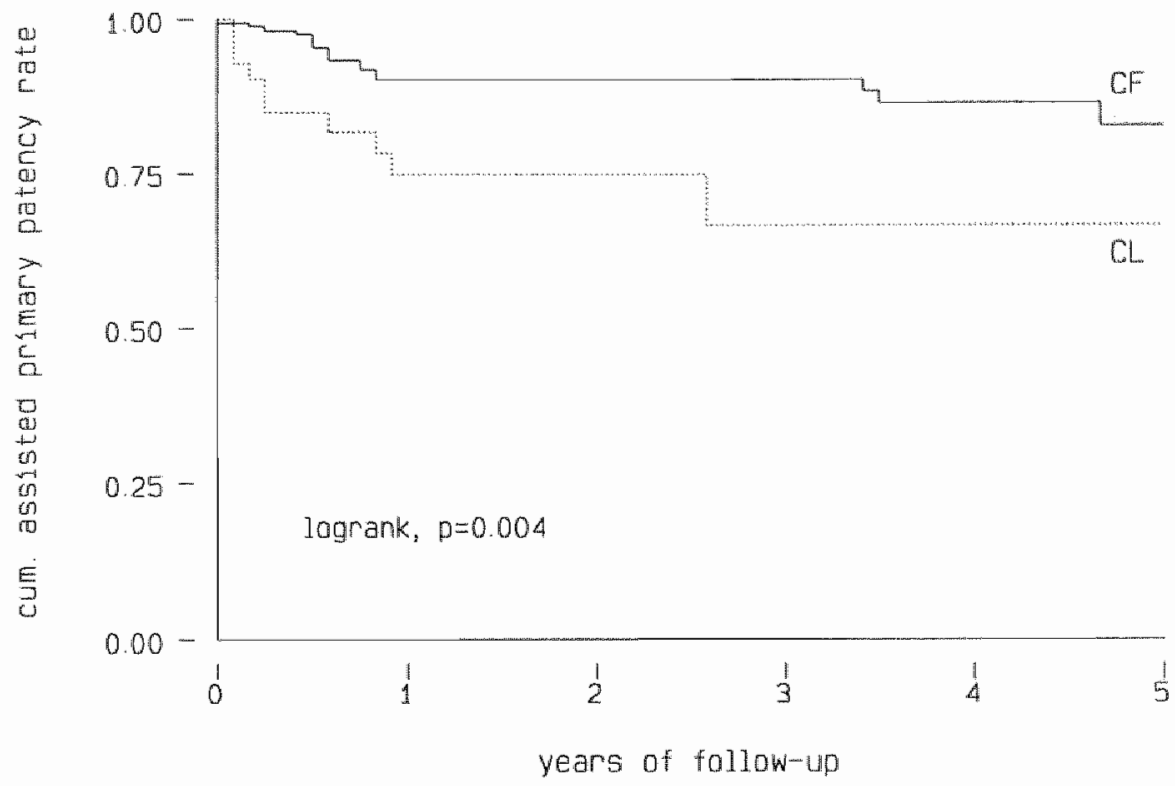

\section{DISCUSSION}

The concept of investigating and repairing of preocclusive vein graft lesions is not new. Since the 1960 s a number of investigators have advocated the salvage of functionally failed grafts by the revision of stenoses before graft thrombosis occurs. ${ }^{17.18}$ Symptoms do not always correlate with patency. In 1979, in a study of 597 grafts, Szilagyi et al. ${ }^{19}$ reported a lack of symptomatic improvement in $6.1 \%$ of patent grafts. When Doppler-recorded blood pressure measurements, frequently complemented by puise volume recordings, had come into general use, patent but hemodynamically failed bypass grafts were identified. The importance of early correction of the anatomic abnormalities was emphasized in these studies. ${ }^{26,20}$ The development of duplex scanning techniques and more recently color-flow duplex scanning enabled the detection of anatomic imperfections in vein grafts not associated with either the presence of symptoms or the deterioration of ankle pressures. ${ }^{311,21,22}$ In the present study, symptoms were present in only $33 \%$ of stenoses, and an interval drop in $\mathrm{ABI}$ was seen in $38 \%$; in comparison, the PSV-index demonstrated $90 \%$ of lesions with a DR greater than $30 \%$ as confirmed with intraarterial DSA. 
Table IIL. Life table primary and assisted primary graft patency analysis for vein grafts that underwent color-flow surveillance and clinical follow-up

Follow-lup

Interval No. at Falled

No.

Intenal Cumulative

Protocol

(mo) risk grafts withdrawn

patency patency $S E$

rate(\%) rate $\%$

Color-fow duplex sumetlance

\begin{tabular}{|c|c|c|c|c|c|c|c|}
\hline \multirow[t]{6}{*}{ Primary patency } & $0-6$ & 160 & 10 & 17 & 94 & 100 & 0.0 \\
\hline & $6-12$ & 133 & 26 & 16 & 80 & 94 & 2.0 \\
\hline & $12-24$ & 91 & 7 & 26 & 92 & 78 & 3.9 \\
\hline & $24-36$ & 58 & 2 & 1.5 & 97 & 72 & 5.0 \\
\hline & $36-48$ & 41 & 2 & 18 & 95 & 69 & 6.0 \\
\hline & $48-60$ & 21 & $\mathbb{1}$ & 9 & 95 & 66 & 8.4 \\
\hline \multirow{6}{*}{$\begin{array}{l}\text { Assisted primary } \\
\text { patency }\end{array}$} & $0 \times 6$ & 160 & 4 & 17 & 98 & 100 & 0.0 \\
\hline & $6-12$ & 139 & 10 & 19 & 93 & 98 & 1.3 \\
\hline & $12-24$ & 110 & 0 & 32 & 100 & 91 & 2.6 \\
\hline & $24-36$ & 78 & 0 & 21 & 100 & 91 & 3.1 \\
\hline & $36-48$ & 57 & 2 & 25 & 96 & 91 & 3.9 \\
\hline & $48-60$ & 30 & 1 & 12 & 97 & 88 & 5.6 \\
\hline
\end{tabular}

Clinical follow-1up

\begin{tabular}{lrrrrrrr} 
Primary patency & $0-6$ & 41 & 7 & 8 & 83 & 100 & 0.0 \\
& $6-12$ & 26 & 5 & 3 & 81 & 83 & 6.7 \\
& $12-24$ & 18 & 1 & 6 & 94 & 71 & 9.0 \\
$24-36$ & 11 & 1 & 4 & 91 & 67 & 11.6 \\
$36-48$ & 6 & 0 & 3 & 100 & 61 & 15.5 \\
& $48-60$ & 3 & 0 & 2 & 100 & 61 & 22.0 \\
& & & & & & & \\
Assisted primary & $0-6$ & 41 & 6 & 8 & 85 & 100 & 0.0 \\
patency & $6-12$ & 27 & 3 & 4 & 89 & 85 & 6.3 \\
& $12-24$ & 20 & 0 & 6 & 100 & 78 & 8.2 \\
& $24-36$ & 14 & 1 & 5 & 93 & 78 & 9.8 \\
& $36-48$ & 8 & 0 & 4 & 100 & 72 & 13.4 \\
& $48-60$ & 4 & 0 & 2 & 100 & 72 & 19.0 \\
\hline
\end{tabular}


Table IV. Determinants of outcome of assisted primary patency in 201 infrainguinal vein grafts by Cox proportional hazard analysis.

\begin{tabular}{lccccc}
\hline & $\begin{array}{c}\text { Estimated } \\
\text { Coefficient }\end{array}$ & SD & Tratio & p-value & $\begin{array}{c}\text { Relative } \\
\text { risk }\end{array}$ \\
& & & & & \\
\hline & & & & & \\
Diabetes mellitus & 0.60 & 0.49 & 1.22 & 0.22 & 1.83 \\
Preoperative ABI $<0.51$ & -0.16 & 0.95 & -0.17 & 0.87 & 0.71 \\
Critical ischemia & 0.85 & 0.68 & 1.25 & 0.21 & 2.33 \\
Hypertension & 0.71 & 0.48 & 1.50 & 0.13 & 2.04 \\
History of smoking & 0.86 & 0.55 & 1.59 & 0.11 & 2.37 \\
History of other vascular disease & -0.28 & 0.49 & -0.57 & 0.57 & 0.76 \\
SvS/ISCVS run-off score $>2.0$ & -0.04 & 0.09 & -0.46 & 0.64 & 0.69 \\
Previous ipsilateral reconstruction & 0.87 & 0.57 & 1.52 & 0.13 & 2.38 \\
In situ vein graft & 0.14 & 0.52 & 0.27 & 0.78 & 1.15 \\
Venovenous anastomosis & 0.54 & 0.54 & 1.00 & 0.32 & 1.72 \\
Crural distal anastomosis & 0.45 & 0.56 & 0.80 & 0.42 & 1.57 \\
Color-flow duplex surveillance & -1.32 & 0.50 & -2.67 & 0.01 & 0.27 \\
& & & & & \\
\hline
\end{tabular}

The diagnostic yield of color-flow duplex scanning can be improved by combining high-velocity and low-velocity criteria. In a recent article Taylor et al ${ }^{2.7}$ found a sensitivity of $100 \%$ and a specificity of $98 \%$ by the combined use of the ratio of the PSV within a stenosis and at a normal graft segment. However, the concept of whether the revision of anatomic lesions that are asymptomatic and do not cause an interval drop in $A B I$ really improves long-term patency has been challenged by some authors. ${ }^{24}$ We have attempted in this study to answer this and other questions that are pertinent to the rationale and outcome of vein graft surveillance.

The incidence of stenotic lesions in vein grafts differs between series, depending on the severity of stenosis that is included and the screening techniques used. In patients monitored clinically and with ankle pressure measurements, the incidence ranges from $5 \%$ to $21 \%$, ${ }^{2,3,25}$ whereas color-flow duplex scanning detected $20 \%$ to $34 \%$ of graft lesions. ${ }^{10,11}$ We found stenoses in $7 \%$ of grafts that underwent clinical followup compared with $32 \%$ in the color-flow surveillance group. This emphasizes that clinical examination and conventional non-invasive testing fail to recognize many graft stenoses, as other researchers have shown. ${ }^{8.26-28}$ Similarly, the rate of repeat interventions varies between series. Our revision rate was $21 \%$, which is comparable to $28 \%$ in the series of 250 vein grafts reported recently by Bandyk et al. ${ }^{7}$ In contrast, in our clinical follow up series only $7 \%$ of failing but patent graft underwent revision. 
Five-year patencies as low as $28 \%$ to $47 \%$ have been documented after revisions performed in grafts that had already thrombosed, as opposed to $82 \%$ to $93 \%$ late patency rates after elective repair of screen-detected stenoses in patent bypasses. ${ }^{3,29}$ In addition, once a screen-derected stenosis has been successfully revised, patency rates of greater than $80 \%$ at 5 years can be achieved, a result similar to that with nonstenosed bypass grafts. ${ }^{7}$ However, we do not know how many stenoses would have progressed to occlusion without revision.

Our analysis differs from earlier studies in that we compared 3-year patency rates in two groups of vein grafts constructed during the same period by the same group of surgeons. The first group of patients took part in a comprehensive color-flow duplex surveillance program, and the second smaller group differed only in that the follow-up was clinically based during the first 2 years. There was no difference in the primary patency rates in the two groups. However, the assisted primary patency was much higher in the color-flow surveillance group, where the intervention rate was greater.

Comparison of patency rates between a group that underwent graft surveillance and a group of historic controls that did not undergo surveillance was reported by Moody et at ${ }^{30}$ These investigators achieved an improwement in 1-year patency rates of $15 \%$ in patients that who were prospectively screened by duplex scanning. Our observation of a $13 \%$ difference in patency rates after 1 year and $19 \%$ after 3 years compares well with these findings. The independent correlation of color-flow surveillance and improved patency rates was confirmed by a proportional hazard model, which showed that the probability of graft occlusion was less than one-third of that with clinical follow-up. No other factors were independently rellated to an increased risk of failure.

The observed rates of stenosis in the two groups leads to the reasonable assumption that two-thirds of stenotic lesions that undergo clinical follow-up remain occult and may cause graft thrombosis. However, there are few data on the natural history of stenotic lesions in bypass grafts and anastomoses. Grigg et al ${ }^{31}$ and Moody et al. ${ }^{13}$ found a $21 \%$ to $23 \%$ incidence of thrombosis in stenotic bypass grafts in which a conservative policy was followed. In the present study of stenotic grafts with and without revision, respectively, $10 \%$ and $39 \%$ failed (Table II), signifying that a graft stenosis is not an innocuous problem. The treatment of graft lesions in our series depended on several factors, such as a waiting list for vascular procedures, patient compliance with therapy, and surgeons diverging attitudes on how aggressive the treatment of these lesions should be. We could therefore correlate the fate of stenoses with active or conservative treatment.

The severity of stenosis was a significant risk factor. No occlusions were seen when stenoses of less than $50 \% \mathrm{DR}$ were treated conservatively. In lesions $50 \%$ to $69 \%$ and $70 \%$ to $99 \%$ DR, respectively, $57 \%$ and $100 \%$ occluded. These findings currently dictate our policy for repeat revision. A revisional procedure is not 
considered in the category with $30 \%$ to $49 \%$ DR. When a lesion of this degree is identified, color-flow duplex scanning is performed at 6 weeks, and thereafter the surveillance schedule is at routine intervals. In the $50 \%$ to $69 \%$ DR category a selective approach is used, and additional factors are considered. For example, lesions longer than $1.5 \mathrm{~cm}$ with an absolute residual diameter greater than $2 \mathrm{~mm}$, as estimated with color flow imaging, are initially observed. Our threshold for performing a balloon angioplasty of a short lesion is rather low. Satisfactory results of balloon angioplasty in lesions with a length of 1 to $1.5 \mathrm{~cm}$ have been reported, whereas surgical correction is the best treatment in longer lesions. ${ }^{32.33}$ Szilagyi ef al. " observed on serial arteriographic examinations that most occlusions occurred in short graft stenoses, whereas grafts with more diffuse intimal thickening tended to remain patent. In a lesion of more than $1.5 \mathrm{~cm}$ length and of intermediate severity we favor a conservative pollicy and use color-flow duplex scanning with reduced intervals to check on progression. As was previously reported by our group, stenoses exceeding $69 \%$ DR are reliably identified by an increase of the EDV to greater than $20 \mathrm{~cm} / \mathrm{s}$ at the site of the stenosis. ${ }^{12}$ Intervention without delay is indicated in all lesions of this severity. A recurrent stenosis after a repeat procedure was encountered in this study in $25 \%$ of cases. This is comparable to the incidence of $17 \%$ to $23 \%$ found in other series. ${ }^{27.32}$ We have separated the true recurrent stenoses from lesions that develop remote from the initial revision site, and it appeared that most tertiary lesions $(80 \%)$ were in fact recurrences. Because of variation in techniques we could not show a correlation with the initial type of revision. However, Bandyk et al. ${ }^{27}$ found that especially for longer lesions a segmental graft replacement is associated with a lower rate of recurrence than is a vein patch angioplasty. A more liberal use of segmental graft replacement or sequential bypass for lesions longer than $2 \mathrm{~cm}$ may reduce the rate of recurrent stenosis.

The enhancement of duplex with color-flow imaging considerably simplifies the examination of vein grafts. ${ }^{10_{0} 11}$ One of the drawbacks of gray-scale duplex is the time involved to search for high-velocity areas. In contrast, color-flow imaging readily identifies stenotic areas, and an improved display of the vessel lumen helps to differentiate stenoses from caliber changes related to the natural tapering of vein grafts. These advantages add to the reliability of the examinations. Although color-flow duplex imaging is currently the best method for graft screening, this examination remains laborious, is expensive, and does not show the run-off vessels well. Simpler tests for repetitive examinations during the first 12 to 18 months have been sought. Graft volume flow measurements do not require longitudinal tracking of the entire bypass graft, and the ratio of the reactive hyperemia and resting flow had been investigated by Chang $e t$ al ${ }^{34}$ They found that this ratio had a limited predictive value for stenotic lesions and a positive test always needed confirmation by a complete duplex examination. Wyatt et al..$^{35}$ reported on non-invasive impedance analysis to identify vein grafts at risk. They observed a good agreement with arteriographically 
diagnosed graft or run-off lesions. The results with this new method will have to be confirmed by others. Inflow and particularly outflow obstructions, may benefit from the development of these new methods. These lesions can cause graft failure as do lesions in the graft itself.

Although many new screening techniques will effectively detect the graft at risk, few will localize the lesion. Most graft stenoses can be well visualized by use of colorflow duplex scanning, and when no multiple lesions are present and the stenosis is focal, revision without confirmatory angiography may be possible. ${ }^{36}$ Furthermore, criteria for quantification of stenoses have been established that enable color-flow duplex scanning to be used reliably as a planning tool. ${ }^{12}$

In conclusion, in our experience a color-flow duplex surveillance program seems to have a significant beneficial effect on infrainguinal vein graft patency. Stenosis detection was improved by more and better revisional procedures. However, prospective validation of these findings is required, and further trials should be directed to the development of a simpler screening method with comparable reliability. When a stenosis is detected by such a non-invasive method, a color-flow duplex examination may be an adequate substitute for pretreatment angiography in some cases. 


\section{REFERENCES}

1. Szillagyi DE, Eliot JP, Haglesman IH, Smith RF, Sallolmo CA. Biological fate of autologous vein implants as arterial substitutes. Ann Surg 1973; 178:232-246.

2. Veith FJ, Weiser RK, Gupta SK, Ascer E, Scher LA, Samson RH, White-Flones SA, Sprayregen $S$. Diagnosis and management of failing lower extremity arterial reconstructions prior to graft occlusion. II Cardiowasc Surg 1984;25:381-384.

3. Cohen JR, Mannick JA, Couch NP, Whittemore AD. Recognition and management of impending vein-graft failure. Importance for long-term patency. Arch Surg 1986;121:758-759

4. Belkin $M$, Donaldson MC, Whittemore AD, Polak JF, Grassi CJ, Harrington DP, Mannick JA. Observations of the use of thrombolytic agents for thrombotic occlusions of infrainguinal vein grafts. J Vasc Surg 1990;11:289-296.

5: Smith CR, Green RM, DeWeese JA. Pseudoocclusiuon of femoropopliteal bypass grafts. Circulation 1983; 68(suppl II):II 88-93.

6. Berkowitz H, Hobbs Ch, Roberts B, Friedman D, Oleaga J, Ring E. Value of routine vascular laboratory studies to identify vein graft stenoses. Surgery 1981;90:971-979.

7. Bandyk DF, Schmitt DD, Seabrook GR, Adams MB, Towne JB. Monitoring functional patency of in situ saphenous vein bypasses: the inapact of a surveillance protocol and clective revision. J Vasc Surg 1989:9:286-296.

8. Green RM, McNamarra J, Ouriel K, DeWeese JA. Comparison of infrainguinal graft surveillance techniques. J Vasc Surg 1990;11:207-215.

9. Disselhoff B, Buth J, Jakimowicz J. Early detection of stenosis of femoro-distal grafts. A surveillance study using colour-duplex scanning. Eur I Vase Surg 1989;3:43-48

1.0. Sladen JG, Reid JDS, Cooperberg PL, Harrison PB, Maxwell TM, Rings MO, Sanders LD. Color flow duplex screening of infrainguinal grafts combining low- and high-velocity criteria. An J Surg 1989;158:107-112.

1. Londrey GL, Hodgson KJ, Spadone DP, Ramsey DE, Barkmeier LD, Summer DS. Initial experience with color-flow duplex scanning of infrainguinal bypass grafts. J Vase Surg 1990;12:284-290.

12. Buth $J$, Disselhoff B, Sommeling C, Stam L. Color-flow duplex criteria for grading stenosis in infrainguinal wein grafts. J Vase Surg 1991;14:716-728

13. Moody $\mathbf{P}_{4}$ deCossart LM, Douglas HM, Harris PL. Asymptomatic strictures in femoropopliteal vein grafts. Eur J Vase Surg 1989;3:389-392.

14. Rutherford RB, Flanigan DP, Gupta SK, et al. Suggested standards for reports dealing with lower extremity ischemia. J Vase Surg 1986;4:80-94

15. Rutherford RB. Reply, Ietters to the editors. J Vasc Surg 1.988;7,718.

16. Cox DR, Regression models and life tables J R Statist Soc (scries B) 1972;34:187-220.

17. Breslau RC, DeWeese JA. Successful endophlebectomy of autogenous wenous bypass grafts. Ann Surg $1965,162: 251-254$.

18. McNamara JJ, Darling RC, Linton RR, Segmental stenosis of saphenous vein autografis: Preventable cause of late occlusion in arterial reconstruction. $N$ Engl J Med 1967;277:290-292.

19. Szilagyi DE, Hageman JH, Smith RF, Elliot JP, Brown F, Dietz P. Autogenous vein grafting in femoropopliteal atherasclerosis: the limits of its effectiveness. Surgery $1979,86: 837-851$.

20. O'Mara CS, Flinn WR, Johnson ND, Bergan JJ, Yao JST. Recognition and surgical management of patent but hemodynamically failed arterial grafts. Ann Surg $1981 ; 193: 467-476$. 
21. Bandyk DF, Cato RF, Towne JB. A low flow velocity predicts failure of femoropopliteal and femorotibial bypass grafts. Surgery $1985,98,799-809$

22. Grigg MJ, Nicolaides AN, Wolfe JHN. Detection and grading of femorodistal vein graft stenoses: duplex measurements compared with angiography. J Vasc Surg 1988;8:661-666.

23. Taylor PR, Tyrrell MR, Crofton M, Bassan B, Grigg M, Wolfe JHN, Mansfield AO, Nicolaides AN. Colour flow imaging in the detection of femoro-distal graft and native artery stenosis: improved criteria. Eur J Vase Surg 1992;6:232-236.

24. Barnes RW, Thompson BW, MacDonald CM, Nix ML, Lambetli A, Nix AD, Johnson DW, Wallace BH. Serial noninvasive studies do not herald postoperative failure of femoropopliteal or fiemorotibial bypass grafts. Ann Surg 1989;210:486-494.

25. Berkowitz HD, Greenstein SM. Improved patency in reversed femoral-infrapopliteal autogenous wein grafts by early detection and treatment of the failing graft. J Vasc Surg 1987;5:755-761.

26. Wolfe JHN, Thomas ML, Jamieson CW, Browse NL, Burnand KG, Rutt DL. Early diagnosis of femorodistal graft stenosis. Br J Surg 1987;74:268-270

27. Bandyk DF, Bergamini TM, Towne JB, Schmitt DD, Seabrook GR. Durability of vein graft revision: The outcome of secondary procedures. I Vase Surg 1991;13:200-210.

28. Mills JL, Harris JE, Taylor LM, Beckett WC, Porter JM. The importance of routine surveillance of distal bypass grafts with duplex scanning: a study of 379 reversed vein grafts. J Vasc Surg $1990 ; 12: 379-389$.

29. Bergamini TM, Towne JB, Bandyk DF, Seabrook GR, Schmitt DD. Experience with in situ saphenous vein bypasses during 1981 to 1989 . Determinant factors of long-term patency. $\mathrm{J}$ Vasc Surg 1991;13:137-149.

30. Moody P, Gould DA, Harris PL. Vein graft surveillance improves patency in femoropopliteal bypass. Eur J Vasc Surg 1990;4:117-121.

31. Grigg MJ, Nicolaides AN, Wolfe JHN. Femorodistal vein bypass graft stenosis. Br I Surg $1988 ; 75: 737-740$.

32. Taylor PR, Wolfe JHN, Tyrrell MR, Mansfield AO, Nicolaides AN, Houston RN. Graft stenosis: Justification for 1-year surveillance. Br J Surg 1990;77:1125-1128.

33. Sanchez LA, Gupta SK, Veith FJ, Goldsmith J, Lyon RT, Wengerter KR, Panetta TF, Marin

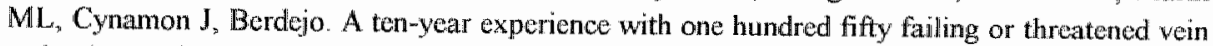
and polyteraffiworocthylene arterial bypass grafts. I Vase Surg 1991;14:729-738.

34. Chang BB, Leather RP, Kaufman JL, Kupinsky AM, Leopold PW, Shah DM. Hemodynamic chacteristics of failing infrainguinal in situ bypass. J Vase Surg 1990;12:597-600.

35. Wyatt MG, Muir RM, Tennant WG, Scott DJA, Baird RN, Horocks M. Impodance analysis to identify the at risk femorodistal graft. IVasc Surg 1991;13:284-293.

36. Moneta GL, Yeager RA, Antonowic R, Hall LD, Caster JD, Cummings CA, Porter JM. Accuracy of lower extremity arterial duplex mapping. J Vasc Surg 1992; 15:275-284. 
Chapter 4

Factors influencing the development of vein graft stenoses and their significance for clinical management

Idu MM, Buth J, Hop WCJ, Cuypers Ph, van de Pavoordt EDWM, Tordoir JMH. Factors influencing the development of vein graft stenoses and their significance for clinical management. (Submitted) 


\section{INTRODUCTION}

Femorodistal bypass operations are performed increasingly often for the treatment of lower limb ischemia. Autologous vein has been the preferred graft material for infrainguinal arterial reconstruction since the use of reversed saphenous vein was first described in 1949 by Kunlin." Unfortunately, $20 \%$ to $30 \%$ of vein grafts develop stenoses in the first postoperative year, due to myointimal hyperplasia ${ }^{2-6}$ The majority of graft stenoses are asymptomatic until they result in a graft occlusion. ${ }^{7}$ Regular noninvisive examinations followed by elective revision of failing but non-occluded grafts have become a valued strategy, which is believed to salvage conduits as well as limbs. ${ }^{8-12}$ Of all non-invasive screening tests frequent duplex ultrasound scanning is, despite the fact that it is time consuming and elaborate, currently the most commonly used method, which has the best correlation with angiography., ${ }^{3,7,13-17} \mathrm{~A}$ surveillance program is generally considered to be indicated for all infrainguinal vein grafts at least for a the first postoperative period. ${ }^{18,19}$ From the view of responsible use of resources it may be advantageous to tailor duplex surveillance programs in such a way that only patients with grafts at higher risk of stenosis are followed by intensive surveillance. Therefore, factors which carry a high or a low-risk for the occurrence of vein graft stenoses need to be defined.

Because a high-grade stenosis is a serious threat to graft patency, a revision to resolve the lesion is indicated without delay. Correction of patent-stenotic grafts has resulted in a superior secondary patency rate compared to revision of occluded-stenotic grafts. ${ }^{9}$ In this report the results are presented of a prospective cohort study of patients with infrainguinal venous bypasses, which were enrolled into a fixed protocol of serial non-invasive testing for the identification of severe lesions in the graft or its adjacent arterial segments. Surgical or catheter interventions were performed when high-grade lesions were confirmed by angiography. In this multicenter study standardized inclusion criteria, uniform surveillance techniques in the participating centers and digital subtraction angiography (DSA) were used in all patients for validation of lesions. Objectives of this analysis were: to assess the influence of a number of clinical and graft factors on the development of stenotic lesions, and to investigate options of modification of grafting techniques or duplex surveillance programs according to proven clinical and graft risk factors.

\section{PATIENTS AND METHODS}

Patients of three institutions following the same surveillance protocol were included in a prospective cohort surveillance study. 300 Patients with autologous vein bypass grafts of the infrainguinal arteries were studied. Patients entered the study if they had 
an open bypass prior to discharge from the hospital. There was only one graft per patient included in this study. This study was a combined effort of three vascular surgical departments: the University Hospital Maastricht (61 grafts), Sint Antonius Hospital Nieuwegein ( 62 grafts), and Catharina Hospital Eindhoven (177 grafts). All centers had a well-equipped and staffed clinical vascular laboratory. 46 Patients with vein grafts operated in the same period were not considered for analysis because of death of the patient (11), irreversible graft occlusion (17), amputation with open bypass within 30 days after the operation (8), or no return for surveillance visits (10). The operations were performed between June 1993 and September 1995 and the Collow-up of this study ended in September 1996. Of the 300 patients $179(60 \%)$ were men, and $121(40 \%)$ were women. The mean age was 70 years (range 33 to 93). Diabetes mellitus (type 1 or 2) was present in $117(39 \%)$ patients. Critical ischemia was the indication for the bypass procedure in $216(72 \%) .83(28 \%)$ Procedures were redo operations, i.e. new grafts, as a previous attempt of revascularization of the popliteal or crural arteries in the same limb had been performed. The distal anastomosis was in $150(50 \%)$ at the level of the popliteal artery or tibioperoneal trunk and in $150(50 \%)$ at a crural artery. The run-off score as determined on the basis of preoperative angiograms ${ }^{20}$ indicated an impaired run-off (score $\left.>2.0\right)$ in $178(59 \%$ ) of the patients. Two hundred thirty seven (79\%) of grafts consisted of a single greater saphenous vein segment, while composite grafts of multiple saphenous or arm-vein segments were used in $63(21 \%)$. Of those $13(4 \%)$ had only arm-vein segments used. Other preoperative risk factors and graft characteristics are summarized in Table $\mathrm{l}$.

Preoperative angiography was performed in all cases to identify the optimal site of the proximal and the distal anastomosis. Duplex assessment of the greater saphenous vein was performed if there was doubt about its suitability. A variety of techniques was used to perform the bypass procedures. In situ saphenous vein grafts were used when the ipsilateral saphenous vein was available and suitable for use. Ectopic veins were either reversed or non-reversed, depending on the vein taper and the optimal size match between vein grafts and inflow and recipient arteries. Small distal or fibrotic segments were replaced by a segment of arm-vein or greater saphenous vein. All operations were performed by vascullar surgeons, vascular fellows, or by residents in their last term of surgical training supervised by a vascular surgeon. All operations were done on either general or epidural anesthesia. Postoperative anticoagulation with coumarins (dicoumarol or acenocoumarol) was instituted postoperatively in all patients that had no contraindications to use. In the three participating institutions the same graft surveillance protocol was used. The adherence to the protocol was accomplished by frequent visits of a data manager and a study nurse, who performed the data collection. Vascular laboratory meetings were organized regularly to ascertain an uniform duplex scanning and measurement 
technique, and recording of parameters. All examinations were performed by qualified technologists.

Table 1. Risk factors and graft characterigtics in 300 infrainguinal vein grafts.

Presenting symptoms

Tissuc loss from $\mathrm{G}$ or $\mathrm{U}$

$109 \quad(36)$

Rest pain

$107 \quad(36)$

Claudication

$78 \quad(26)$

Aneurysm

Associated disease and risk factors

Female gender

Diabetes mellitus

Hypertension

History of smoking

$210 \quad(70)$

History of other vascular disease

$152(51)$

Preoperative data
$\mathrm{ABI}<0.60$
$223(78)^{2}$
SVS/ISCVS' run-off score $>2.0$
178 (59)

Graft

Prewious ipsilateral infrainguinaل reconstruction

Other than in situ graft

Proximal anastomosis below common femoral artery $111 \quad$ (37)

Crural distal anastomosis

$150 \quad(50)$

Venovenous anastomosis

54 (18)

ABI is ankle brachial blood pressure index; $\mathrm{G}$ is gangrene; $U$ is ulceration; 1 : SVS/ $\mathrm{SSCVS}$ is Society for Vascular Surgery / International Society for Cardiovascular Surgery; 2: incompressible vessels in 15 patients. 


\section{Surveillance protocol}

Before discharge from the hospital graft patency was confirmed by a graft velocity measurement at mid-thigh level of the bypass. Entire graft intraoperative or predischarge duplex scanning was infrequently performed during this study, therefore these data were not included in the analysis. For the study, however, only the outcomes of entire bypass duplex scannings during follow-up were used in addition with ankle pressure measurements at rest and during reactive hyperemia (RH). Surveillance visits were routinely performed at 6 weeks, 3 months, 6 months, 9 months and 12 months. In grafts without abnormalities subsequent follow-up examinations consisted of ankle blood pressure measurements at rest and during RH at 18, 24 and 30 months after the operation. The rationale for restricting duplex examinations to the first postoperative year has been well-documented in the literature ${ }^{3}$. An intraarterial DSA (Catharina Hospital and Sint Antonius Hospital) or an intravenous DSA (University Hospital Maastricht) was performed if one of the following criteria for a failing graft were present: recurrent claudication or rest pain, interval decrease of the $\mathrm{ABI}>0.15$, a peak systolic velocity ratio (PSV-ratio) $>2.0$, a peak systolic velocity at the mid-thigh graft (PSV-graft) $<45 \mathrm{~cm} / \mathrm{s}$, and an end-diastolic velocity (EDV) $>20$ $\mathrm{cm} / \mathrm{s}$. If the intravenous study had insufficient resolution a subsequent intraarterial DSA was performed. Accurate assessment of the angiographic diameter ratio of stenotic and normal graft sites was facilitated by multiple projections as well as by magnified views. If at DSA examination a stenosis of $70 \%$ diameter reduction (DR) or greater was observed either in the graft, the anastomoses or in the adjacent artery segments a revisional procedure, either a PTA or an open surgical procedure, was planned. In fact, this angiographic criterium was the sole determinant for the decision for intervention. After lesion repair surveillance was continued until one year after the revision. In case of a stenosis with a DR of $50 \%$ to $70 \%$ no intervention was undertaken, but subsequent surveillance duplex examinations were performed at reduced intervals. If there was no further increase of the PSV-ratio a conservative approach was adopted and the surveillance schedule resumed at routine intervals. Bypasses with less than 50\% DR were considered normal grafts. Patients without evidence of graft stenosis at surveillance examination underwent a DSA after their consent was obtained. These control DSA studies were made either 6 months or $\downarrow$ year after the operation, a choice that was determined by randomization. 


\section{Surveillance examination}

Systolic ankle blood pressure $(A B P)$ measurements were performed with the patient supine using a $15 \mathrm{~cm}$ wide blood pressure cuff, and the average of two measurements was recorded. The highest of the right and left systolic brachial blood pressure was used to determine the ankle brachial blood pressure index (ABI). Ankle blood pressure during reactive hyperemia was measured following suprasystolic thigh cuff inflation during a 3-minute period. The color-flow duplex equipment that was used consisted of a Acuson $128 \mathrm{XP} / 10$ in the Catharina Hospital, a Hewlett Packard Sonos 1000 in the University Hospital Maastricht and a Hewlett Packard Sonos 2000 in the Sint Antonius Hospital. In the three centers a $7.5 \mathrm{MHz}$ transducer was applied, unless the vein graft was deep, when a $5.0 \mathrm{MHz}$ transducer was used. The examination technique, such as the use of similar angles of insonation of the pulsed Doppler with respect to the vessel axis, sites of velocity measurements, ankle blood pressure measurements and reactive hyperemia induction was uniform in the participating vascular laboratories. The vein graft was examined from the groin down the entire length to below the distal anastomosis on to the first centimeters of the recipient run-off artery. Color coded images were studied for stenotic flow patterns and a percent diameter reduction (DR) was measured by use of color-image at the stenosis and at a nearby normal graft segment. After the graft was imaged midstream pulsed Doppler velocity spectral signals were recorded from diseased and normal vessel segments.

\section{The clinical and graft factors}

The recorded preoperative clinical factors recorded included: (1) indication for revascularization, (2) preoperative ankle brachial blood pressure index, (3) presence of diabetes mellitus, (4) smoking habits, (5) hypertension, (6) angina pectoris or (7) previous history of myocardial infarction, (8) of myocardial revascularization, (9) of central vascular reconstruction or $(10)$ of peripheral vascular reconstructions. These factors were diagnosed and graded according to the Suggested Standards for Reports Dealing with Lower Limb Ischemia. ${ }^{22}$ In addition the following graft characteristics were recorded: (1) grafting technique, (2) anastomotic sites, (3) site of any venovenous anastomoses, (4) external diameters of the vein graft, and (5) total length of the graft prior to wound closure. In addition the intraoperation quality control method was recorded, which either was angioscopy, angiography or duplex examination. Peroperative graft factors were recorded on a standardized form filled in by the operating surgeon immediately after the procedure.

To assess the occurrence of graft stenoses, regularly measured PSV-ratios were used as an indicator of significan graft stenosis, which was defined as a PSV-ratio 22.5. Event causing stenosts was defined if a stenosis required a revision. All revised lesions had a diameter reduction greater than $70 \%$ on confirmatory angiography. In 
addition, stenoses that had caused a graft occlusion before a revision was undertaken, were also defined: event causing stenoses.

\section{Data analysis}

The occurrence of significant graft stenosis and event causing grafi stenosis were the end-points of patency and were correlated with the different factors. The time interval between the operation and the occurrence of the stenosis was recorded. Univariate comparison between the stenotic and non-stenotic grafts was performed for all defined patient and bypass characteristics using logrank testing. To examine independent associations variables with significant group differences at univariate comparison were combined with some factors of particular clinical relevance and were subjected to a multiple regression analysis using a Cox proportional hazard model. ${ }^{21}$ For these analyses SPSS 7.0 for Windows statistical software was used.

\section{RESULTS}

\section{Vein graft stenoses}

17 Preoperative risk factors and graft characteristics were correlated with the occurrence of two different end-points, i.e. the development of significant grafi stenosis and event causing graft stenosis during follow-up. The univariate correlation of all variables with the two endpoints during follow-up is indicated in Table II. The only factor for which a statistically significant correlation with the development of significant graft stenosis could be demonstrated was the minimal graft diameter. The other factors did not have statistical correlation with the development of significant graft sienosis. Factors that had a significant correlation with the development of event causing graft stenosis were the minimal graft diameter, use of venovenous anastomosis and the length of the graft (Table II).

These 3 factors were selected for a multivariate analysis with a Cox proportional hazard model ${ }^{23}$ with event causing graft stenosis as endpoint (Table III). Some additional clinically relevant risk factors were selected for this analysis as well. These factors were: (1) site of distal (crural) anastomosis, (2) grafting technique (non in situ technique), (3) previous peripheral revascularization and (4) indication for the operation (rest pain or gangrene). The minimal intraoperatively measured graft diameter showed to be the single independent factor, that significantly correlated with the development of event causing graft stenoses during subsequent follow-up overtoning the other variables. 
Table Il. Univariate corrclation of preoperative clinical and graft parameters and the occurrence of stgrifficant or event causing vein graft stenosis.

\begin{tabular}{|c|c|c|c|c|c|c|}
\hline Parameler & & $\begin{array}{c}\text { No. } \\
\text { of } \\
\text { patients }\end{array}$ & $\begin{array}{l}\text { ignificant graft st } \\
\text { P-year } \\
\text { free-of-stemosis } \\
\text { rate (\%) }\end{array}$ & $\begin{array}{l}\text { tenosis } \\
\text { logrank } \\
\text { p-watue }\end{array}$ & $\begin{array}{c}\text { Ewent causing gra) } \\
\text { l-year } \\
\text { free-of-stenosis } \\
\text { rate }(\%)\end{array}$ & $\begin{array}{l}\text { ft stemosis } \\
\text { logrank } \\
\text { p-value }\end{array}$ \\
\hline \multirow[t]{2}{*}{ Critical limb ischernia } & No & 84 & 66 & & 78 & \\
\hline & Yes & 216 & 60 & $0.5 !$ & 70 & 0.051 \\
\hline \multirow[t]{2}{*}{ Diabetes mellitus } & No & 183 & 66 & & 72 & \\
\hline & Yes & 117 & 54 & 0.16 & 72 & 0.74 \\
\hline \multirow[t]{2}{*}{ Smoking } & No & 168 & 58 & & 69 & \\
\hline & Yes & 132 & 66 & 0.32 & 75 & 0.63 \\
\hline \multirow[t]{2}{*}{ Hypertension } & No & 206 & 63 & & 75 & \\
\hline & Yes & 94 & 58 & 0.24 & 66 & $0.2 \mathbb{1}$ \\
\hline \multirow[t]{2}{*}{ Angina Pectoris } & No & 250 & 61 & & 70 & \\
\hline & Yes & 50 & 64 & 0.40 & 80 & 0.36 \\
\hline \multirow[t]{2}{*}{ Myocardiall Infarction } & No & 203 & 60 & & 70 & \\
\hline & Yes & 97 & 66 & 0.24 & 77 & 0.32 \\
\hline \multirow[t]{2}{*}{ PTCA / CABG ${ }^{1}$} & No & 259 & 63 & & 73 & \\
\hline & Yes & 41 & 53 & 0.35 & 63 & 0.17 \\
\hline \multirow[t]{2}{*}{ Previous central tecon. } & No & 271 & 63 & & 71 & \\
\hline & Yes & 29 & 53 & 0.50 & 78 & 0.77 \\
\hline \multirow[t]{2}{*}{ Previous peripheral recon. } & No & 217 & 61 & & 71 & \\
\hline & Yes & 83 & 64 & 0.8 & 74 & 0.74 \\
\hline \multirow[t]{2}{*}{ Preoperative $\mathrm{ABI}^{2}$} & $<0.60$ & 223 & 62 & & 73 & \\
\hline & $\geq 0.60$ & 62 & 62 & 0.83 & 70 & 0.66 \\
\hline \multirow[t]{2}{*}{ SVS/ISCVS ${ }^{3}$ nun-off score } & $\leq 2.0$ & 122 & 65 & & 76 & \\
\hline & $>2.0$ & 178 & 59 & 0.33 & 70 & 0.15 \\
\hline
\end{tabular}


Table II - continued. Univariate correlation of preoperative clinical and graft parameters and the occurrence of significant or event causing wein graft stenosis.

\begin{tabular}{|c|c|c|c|c|c|c|}
\hline Parameter & & $\begin{array}{c}\text { No. } \\
\text { of } \\
\text { patients }\end{array}$ & $\begin{array}{c}\text { Significant grafi } \\
\text { l-year } \\
\text { free-af-stenosis } \\
\text { rate }(\%)\end{array}$ & $\begin{array}{l}\text { stenasis } \\
\text { logrank } \\
\text { p-ralue }\end{array}$ & $\begin{array}{c}\text { Ewent causing gro } \\
\text { l-year } \\
\text { free-of-stenosis } \\
\text { rate (\%) }\end{array}$ & $\begin{array}{l}\text { ff stenosis } \\
\text { logrank } \\
\text { p-valtue }\end{array}$ \\
\hline \multirow[t]{2}{*}{ Grafting technque } & in situ & 128 & 58 & & 72 & \\
\hline & non in situ & 172 & 64 & 0.42 & 71 & 0.82 \\
\hline \multirow[t]{3}{*}{ Proximal anast. } & $\mathrm{CFA}^{4}$ & 189 & 59 & & 68 & \\
\hline & Prox. SFA & 52 & 58 & & 79 & \\
\hline & Dist. SFA/Popl. & $11^{6} 59$ & 71 & 0.39 & 80 & 0.21 \\
\hline \multirow[t]{2}{*}{ Crural anastomosis } & No & 150 & 64 & & 75 & \\
\hline & Yes & 150 & 60 & 0.49 & 68 & 0.11 \\
\hline \multirow[t]{2}{*}{ Minimal graft diam. } & $<3.5 \mathrm{~mm}$ & 38 & 41 & & 48 & \\
\hline & $\geq 3.5 \mathrm{~mm}$ & 262 & 65 & 0.002 & 75 & 0.001 \\
\hline \multirow[t]{2}{*}{ Venovenous anast. } & No & 246 & 64 & & 75 & \\
\hline & Yes & 54 & 51 & 0.09 & 58 & 0.005 \\
\hline \multirow[t]{3}{*}{ Length of graft } & $\leq 40 \mathrm{~cm}$ & 100 & 66 & & 77 & \\
\hline & $40-60 \mathrm{~cm}$ & 140 & 61 & & 73 & \\
\hline & $>60 \mathrm{~cm}$ & 60 & 54 & 0.46 & 61 & 0.025 \\
\hline
\end{tabular}

1. PTCA/CABG is percutaneous transluminal coronary angioplasty / coronary atorta bypass graft; 2 . ABII is ankle brachial pressure index, incompressible vessels in 15 patients; 3 . SVS/ISCVS is Society for Vascular Surgery / International Society for Cardiovascular Surgery, 4. CFA is common fomoral artery; 5. Prox. SFA is proximal superficial femoral artery; 6. Dist. SFA/ Popl. is distal superficial femoral artery / popliteal artery. 
Table IIr. Cox proportional hazard model relating several factors and occurrence of event causing weingrafis sienosis.

\begin{tabular}{lcccc} 
Pactor & $\beta$ & $S E$ & Wald & Sign. \\
\hline Minimal graft diameter & -0.70 & 0.27 & 6.8 & 0.009 \\
Venowenous anastomosis & 0.47 & 0.26 & 3.17 & 0.08 \\
Length of graft & 0.19 & 0.17 & 1.14 & 0.29 \\
Crural anastomosis & -0.05 & 0.26 & 0.03 & 0.85 \\
Grafting technique & -0.01 & 0.23 & 0.002 & 0.96 \\
Previous peripheral recon. & -0.11 & 0.25 & 0.20 & 0.65 \\
Critical ischemia & 0.33 & 0.28 & 1.40 & 0.24
\end{tabular}

The factors were categorized into subgroups the same way as described in Table II.

Kaplan-Meier curves indicating a free-of-stenosis state were constructed with the occurrence of significant stenosis as the event (Figure 1). Groups with a intraoperatively measured minimal graft diameter $<3.5 \mathrm{~mm}$ (group 1), between 3.5 and $4.5 \mathrm{~mm}$ (group 2), and $>4.5 \mathrm{~mm}$ (group 3) were compared. At one year group 1, 2, and 3 had free-of-stenosis rates of $40 \%, 58 \%$, and $75 \%$ respectively. Group 1 differed from groups 2 and 3 ( $p$, respectively $0.02,<0.001$ ), and group 2 differed from group 3 ( $p=$ $0.03)$.

\section{Grafting techniques}

To investigate the role of the grafting technique the results in grafts with a minimal diameter of $<3.5 \mathrm{~mm}$ measured intraoperatively, and the results in grafts modified by the use of multiple composite vein segments or arm-veins to obtain a wider conduit, were compared. Thus, two groups were defined: group A consisting of 25 single segment greater saphenous vein grafts, all with a minimal graft diameter of $<3.5 \mathrm{~mm}$, and group $B$ consisting of 11 arm-vein grafts and 41 composite vein grafts, all with a minimal diameter of $>3.5 \mathrm{~mm}$. Life table analysis demonstrated no difference in freeof-srenosis rate with the occurrence of significant graft stenosis as the event between group A and B, with 12 month patencies of $38 \%$ and $55 \%$ respectively $(p=0.1)$. However, the secondary patency at one year was $76 \%$ and $94 \%$ respectively, which represented a significant difference $(p=0.03)$. The 1-year secondary patency in group $B$ was comparable with the patency of grafts which consisted of a single segment greater saphenous vein with a minimal diameter of $>3.5 \mathrm{~mm}, 94 \%$ and $93 \%$ respectively. If only femorocrural grafts were considered the 1 -year secondary patency 
in group A (20 femorocrural grafts) and group B ( 24 femorocnual grafts) were $75 \%$, and $91 \%$ respectively, which difference was not significant.

Figure 1. Rate of maintenance of free-of-sienosis state, defined as a focal PSV-ratio $>2.5$, represented by Kaplan-Meier curves in patient groups according to the intraoperatively measured minimal graft dianeter. group 1 (dian. $<3.5 \mathrm{~mm}$ ), group 2 (diam, 3.5 to 4.5 $\mathrm{mm}$ ) and group 3 (diam. $>4.5 \mathrm{~mm}$ (group 3). (group $1 \mathrm{vs}$ group 2: $p=0.02$, group I vs group 3: $p<0.001$, group 2 ws group $3 ; p=0.03$ ).

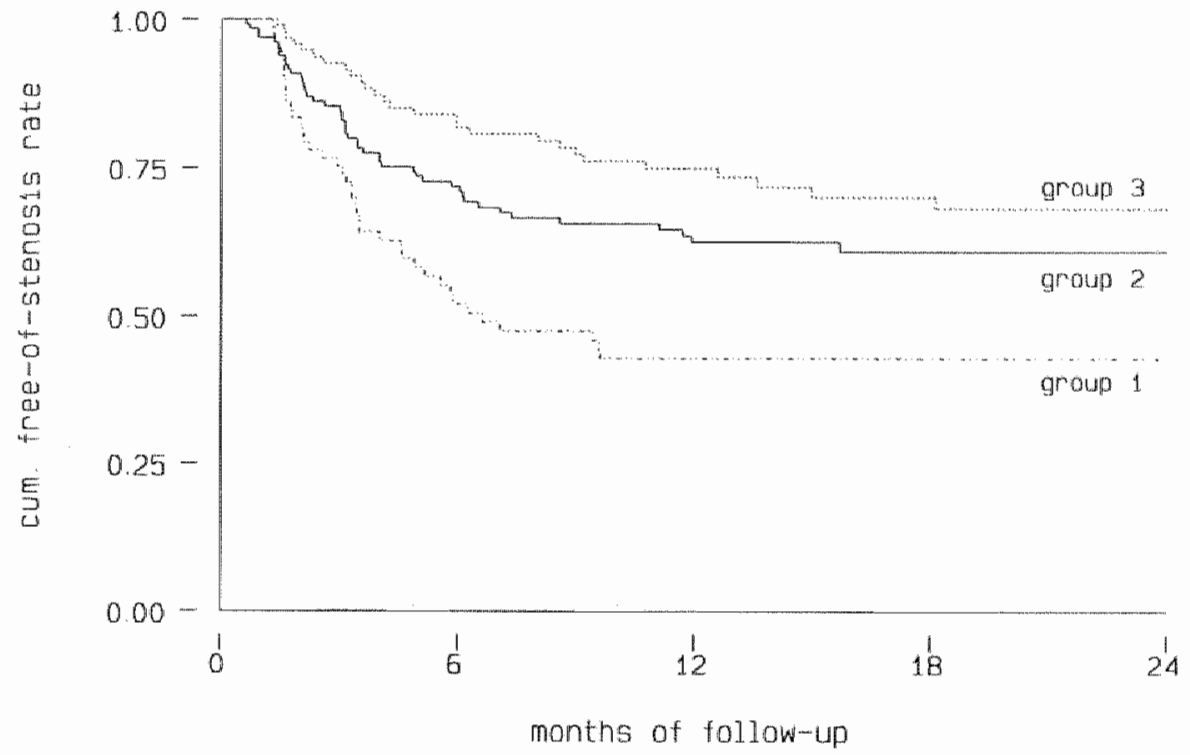

\section{DISCUSSION}

After discharge the majority of graft failures occur within the first two years and progressive graft stenosis is the most frequent cause. These lesions are caused by myointimal hyperplasia which usually is a focal process. It may occur throughout the graft as well as in the areas of the anastomoses. ${ }^{22}$ Color-flow duplex surveillance programs are effective in detecting these lesions prior to graft occlusion, allowing interventions with good expectation on success. ${ }^{8,10-13}$ Other non-invasive tests, such as ankle blood pressure measurements have not nearly been as accurate in identifying stenotic graft lesions. ${ }^{14-17}$ An optimal surveillance program implies all infrainguinal 
venous grafts to be screened. However, a comprehensive follow-up of this nature is extremely time consuming and associated with high costs.

A number of studies have been focussed to unravel the origin of vein graft stenoses. ${ }^{2422}$ Assessment of influence of several preoperative patient and intraoperatively determined graft characteristics on stenosis formation was the subject of the present analysis. Of all factors investigated in our study the minimal graft diameter appeared the single variable that significantly correlated with the occurrence of graft stenosis. Markers of advanced atherosclerosis, such as diabetes mellitus, the presence of critical limb ischemia, a high run-off score, and the presence of tissue necrosis, were not correlated with a higher rate of vein graft stenosis. Operative technical factors, such as site of the distal anastomosis (crural arteries) and the graft technique (i.e. non in-situ technique) failed to show any significant correlation with the occurrence of vein graft stenosis either. Although the minimal graft diameter is an important risk factor for vein graft stenosis development, it is difficult to stratify patients into a group in which surveillance is particularly indicated and a group that does not require regular duplex testing at follow-up. Patients with a graft diameter $\geq 3.5$ $\mathrm{mm}$ still develop stenoses considered a 1-year free-of-stenosis rate of $58 \%$ and $75 \%$ of grafts with a minimal graft diameter between 3.5 to $4.5 \mathrm{~mm}$ and $>4.5 \mathrm{~mm}$ respectively. These incidences are, in our opinion, not acceptable to justify denying patients in these categories a duplex surveillance program. Our findings are in agreement with other studies, that also documented an unfavorable effect on durable patency of small caliber grafts. ${ }^{23-25}$ Grafts bearing segments with a less than $3.5 \mathrm{~mm}$ diameter are at increased risk of failure for several reasons. It has been suggested that small caliber vein grafts are more vulnerable to intraoperative damage during harvesting than larger vein grafts. This was particularly true during valve lysis associated with the in situ technique. Injury of this nature may initiate local myointimal hyperplastic response, which may in small caliber veins result in high-grade stenoses. Moreover, small vein grafts may result from previous episodes of phlebosclerosis or have other pre-existing saphenous vein pathology. The presence of pre-existing saphenous vein pathology renders the overall quality of the conduit. ${ }^{26,27}$ In their study Bandyk et al. demonstrated that peroperatively diagnosed graft lesions were significant promoters of the development of vein graft stenoses. ${ }^{28}$ Also the observation that none of the factors, generally assumed to reflect a poorer general vascular status of the patient, did show a correlation with the development of vein graft stenosis tended to support the hypothesis that vein graft stenosis is caused by local graft-related factors, such as preexisting vein pathology and operative injuries to the conduit. To assess the role of discrete peroperatively diagnosed abnormalities of the vein graft in subsequent development of vein graft stenosis we now perform a predischarge duplex examination including scanning of the entire vein graft and its adjacent arterial segments. This analysis will be the subject of a future study. 
At the present time we hesitate to use small caliber segments of a vein graft; because of a high incidence of failure. Altemative sources of autologous vein segments, such as the contralateral saphenous vein or arm-veins, are preferred instead. Earlier studies demonstrated satisfactory results with the use of arm-veins and spliced grafts. ${ }^{29-32}$ In our series composite vein grafts and arm-vein grafts both with a minimal diameter of $>3.5 \mathrm{~mm}$ had a one year free-of-sienosis rate of $55 \%$ compared with $38 \%$ in the group with single greater saphenous grafts with a minimal diameter $<3.5 \mathrm{~mm}$. This difference just failed to reach statistically significance, perhaps due to small group sizes. However, the secondary patency rate was significantly better in the combined group with composite vein and arm-vein grafts compared to small caliber single greater saphenous vein grafts. This pattern indicates that grafts of arm vein or composite vein grafts have a tendency to develop less frequently stenotic lesions, while in addition treatment of these lesions is more often successful. An additional alternative therapeutic option when just a short vein segment is available, due to a small or fibrosed segment, may be the use of an open superficial femoral artery segment or popliteal artery as the site of the proximal anastomosis. ${ }^{33,34}$ The number of short vein grafts in the present study was too small for a useful analysis.

The results reported in the literature about prosthetic grafts varied, but in particular if femorocrural grafts are considered low patencies were observed. ${ }^{35-38}$ The secondary patency rates were between $5 \%$ and $55 \%$. In contrast, in our series the 1 year secondary patency rate of femorocrural grafts with composite vein and arm-vein grafts was $91 \%$. These results are in concordance with those of Harward et al., and of Chalmers et al., who reported 1-year secondary patencies of $85-91 \%{ }^{39,40}$ It may be concluded from our own observations as well as those of others that the use of armvein or composite vein grafts for femorocrural bypass grafting is the preferable option if the saphenous vein is less than $3.5 \mathrm{~mm}$ in width. 


\section{REFERENCES}

1. Kunlin J. Le tratment de l'arterite abliterante par la greffe weineuse. Arch Chir Mal Coeur $1949 ; 42: 371-372$

2. Szilagy DE, Eliot JP, Haglesman JH, Smith RF, Sallolmo CA. Biological fate of autologous vein implants as arterial substitutes. Ann Surg 1973;178:232-246.

3. Grigg MJ, Nicolaides $A N$, Wolfe JHN. Femorodistall vein bypass graft stenosis. Br J Surg $1988 ; 75: 737-740$.

4. Sladen JG, Gilmour JL. Vein graft stenosis: characteristics and effect of treatment. An J Surg 1981:41:549-553.

5. Whittemore AD, Clowes AW, Couch NP, Mannick IA. Secondary femoro-popiteal reconstruction. Ann Surg 1981;193:35-42.

6. Wilson YG, Davies AH, Currie IC, Morgan M, McGratl C, Baird RN, Lamont PM. Vein graft. stenosis: Incidence and Intervention. Eur J Vasc Endovase Surg 1996;11:164-169.

7 Idu MM, Truyen $\mathbb{E}_{\mathrm{x}}$ Buth J. Surveillance of lower extremity vein grafts. Eur J Vase Surg 1992;6:456-462.

8. Bandyk DF, Schmitt DD, Seabrook GR, Adans MB, Towne JB. Monitoring functional patency of in situ saphenous vein bypasses. the impact of a surveillance protocol and elective revision. J Vasc Surg 1989;9:286-296.

9. Cohen JR, Mannick JA, Couch NP, Whittemore AD. Recognition and managenent of impending vein-graft failure. Importance for long-term patency. Arch Surg 1986;121:758-759.

10. Moody P, Gould DA, Harris PL. Vein graft surveillance improves patency in femoropopliteal bypass. Eur J Vasc Surg 1990;4:117-121

11. Lundall A, Lindblad B, Bergqwist D, Hansen F. Femoropopliteal-crural graft patency is improved by an intensive surveillance program: A prospective randomized study. J Vase Surg 1995,21:2634.

12. Idu MM, Blankensteyn JD, de Gier P, Truyen E, Buth J. Impact of a color-flow duplex. surveillance program on infrainguinal vein graft patency. A five-year experience. $J$ Vasc Surg $1993 ; 17: 42-53$.

13. Disselthoff $\mathbf{B}_{*}$ Buth $\mathrm{J}$, Jakimowicz $\mathrm{J}$. Early detection of stenosis of femoro-distal grafts. A surveillance study using colour-duplex scanning. Eur J Vasc Surg 1989;3:43-48.

14. Barnes RW, Thompson BW, MacDonald CM, Nix ML, Lambeth A, Nix AD, Johnson DW, Wallace BH. Serial noninvasive studics do not herald postoperative failure of femoropopliteal or femorotibial bypass grafts. Ann Surg 1989;210:486-494

15. Gren RM, McNamara J, Ouriel K, DeWeese JA Comparison of infrainguinal graft surveillance tochniques. J Vasc Surg 1990; J 11:207-215

16. Brennan JA, Watsh AKM, Beard JD, Bolia AA, Bell PRF. The role of simple non-imvasive lesting in infrawinguinal wein graft surveillance. Eur J Vasc Surg 1991;5:13-17.

17. Bandyk DF. Postoperative surveillance of infrainguinal bypass. Surg Clin North Am 1990;70:7185.

18. Taylor PR, Wolfe JHN, Tyrrell MR. Mansfield AO, Nicolaides AN, Houston RN Graft stenosis: Justification for 1-year surveillance, Br J Surg 1990;77:1125-1:128

19. Mohan CR, Hoballah JJ, Schueppert MT, Sharp WJ, Kresowik TF, Miller EV, Corson ID Should all in situ saphenous vein bypasses undergo permanent duplex scanning? Arch Surg $1995: 130: 483488$. 
20. Rutherford RB, Flanigan DP, Gupta SK, al. Suggested standards for reports dealing with lower extremity ischemia. I Vasc Surg 1986;4:80-94.

21. Cox DR. Regression models and life tables J R Statist Soc (serias B) 1972;34:187-220.

22. Towne JB. Role of fibrointimal hyperpllasia in vein graft tailure. IVase Surg 1989;10:583-585.

23. Varty $\mathrm{K}$, London $\mathrm{NJ}$, Brennan JA, Ratliff DA, Bell PRF. Infragenicular in situ vein bypass graft occlusion. A multivariate risk factor analysis. I Vasc Surg 1993;7,567-571.

24. Wengerter KR, Veith FJ, Gupta SK, Ascer E, Rivers SP. Influence of vein size (diameter) on infrapopliteal reversed vein graft patency. J Vasc Surg 1990;11:525-531.

25. Towne JB, Schmitt DD, Seabrook GR, Bandijk DF. The effect of vein diameter on early patency and durability of in-situ bypass grafts. J Cardiovasc Surg 1989;30:64

26. Marin ML, Veith FJ, Panetta TF, Gordon RE, Wengerter KR, Suggs WD, Sanchez L, Parides MK. Saphenous vein biopsy: a predictor of wein graft failure J Vase Surg 1993;18;407-414.

27. Panetta TF, Marin ML, Veith FJ, Goldsmith J, Gordon RE, Jones AM, Schwartz ML, Gupta. SK. Wengerter KR. Unsuspected preexisting saphenous wein disease: an unrecognized cause of vein bypass failure. J Vasc Surg 1992; 15:102-110.

28. Bandyk DF, Johnson BL, Gupta AK, Esses GE. Nature and management of duplex abnomalities encountered during infrainguinal vein bypass grafting. J Vase Surg 1996;24:430-438.

29. Balshi JD, Cantelmo NL, Menzoian JO, LoGerfo FW. The use of arm veins for infrainguinal bypass in end-stage peripheral vascular disease. Arch Surg, 124:1078-1081

30. Londrey GL, Bosher LP, Brown PW, Stonebumer FD, Pancoast JW, Davis RK. Infrainguinal reconstruction with arm vein, lesser saphenous vein, and remmants of greater saphenous vein. J Vasc Surg 1994;20:451-457.

31. Chang BB, Darling RC 3rd, Bock DE, Shah DM, Leather RP. The use of spliced vein bypasses for infrainguinal arterial reconstruction. J Vase Surg 1995;21:403-412.

32. Gentile AT, Lee RW, Moneta GL, Taylor LM, Edwards JM, Porter JM. Results of bypass to the popliteal and tibial arteries with alternative sources of autogenous vein. J Vasc Surg $1996 ; 23: 272-280$.

33. Rosenbloom MS, Walsh JJ, Schuler JJ, Meyer JP, Schwartz TH, Eldrup-Jorgensen J, Durhan JR, Flanigan DP. Long-term results of infragenicular bypasses with autogenous vein, originating from the distal superficial femoral and popliteal arteries. J Vase Surg 1988;7,691-696.

34. Wengerter KR, Yang PM, Veith FJ, Gupta SK, Panctta TF. A twelve-year experience with the politeall-to-distal artery bypass. I Vasc Surg 1992;15:143-151.

35. Parsons RE, Suggs WD, Veith FJ, Sanchez LA, Lyon RT, Marin ML, Goldsmith J, Fanics PL, Wengerter KR, Schwartz ML. Polytetrafluoroethylene bypasses to infrapoplitcal arterics without cuffs or patches: a better option than amputation in patients without autologous vein. J Vase Surg $1996,23: 347-354$

36. Morris GE, Raptis S, Miller JH, Faris IB. Femorocrural grafting and regrafting: docs polytetrafluoroethylene have a role? Eur I Vasc Surg 1993;7:329-334.

37. Van de Pavoordt EDWM, Eikelboom BC, De Geest R, Vermeulen FE. Results of prosthetic grafts in femoro-crural bypass operations as compared to tutogenous saphenous vein grafts. Neth J Surg 1986;38:177-179.

38. Veith FJ, Gupta SK, Ascer E, White-Flores S, Samson RH, Scher LA, Towne JB, Bernhard VM, Bonier P, Flinn WR. Six-year prospective multicenter randomized comparison of autologous saphenous vein and expanded polytetrafluoroetlyylene grafts in infrainguinal arterial reconstructions. J Vase Surg 1986;3:104-114 
39. Harward TRS, Coe D, Flyn TC, Seeger JM. The use of arm vein conduits during infrageniculate arterial bypass. I Vase Surg 1992,16:420-427.

40. Chalmers RTA, Haballah JJ, Kresowik TF, Sharp WJ, Synn AY, Miller E, Corson ID. The impact of color duplex surveillance on the outcome of lower limb bypass with segments of arm veins. IV Vase Surg 1994;19:279-288 
Chapter 5

\section{Diagnostic accuracy of several surveillance parameters to detect vein graft stenoses}

Part of this chapter has been published as:

Idu MM, Buth J, Hop WCJ, Cuypers Ph, van de Pavoord EDWM, Tordoir JMH.

Vein graft surveillance: Is graft revision without arteriography justified and what criteria should be used? J Vasc Surg 1998;27:399-413. 


\section{INTRODUCTION}

Autogenous vein grafts provide the best conduit for bypass treatment of femoropopliteal and femorocrural occlusive disease. However, bypass longevity is threatened by the development of stenoses, either from intimal hyperplasia or from fibrous stricture development in $20 \%$ to $30 \%{ }^{1-3}$ Frequent non-invasive examinations followed by elective revision of failing, but non-occluded grafts has become a valued strategy, which is believed to salvage conduits as well as limbs. ${ }^{4-7}$ Arteriography allows the demonstration of significant vein graft stenoses and in fact this method was used in the first comprehensive study reporting on the phenomenon of graft stenosis by Szilagyi et al. in 1973. "The presence of a significant arteriographic stenosis is a reliable predictor of graft failure unless the lesion is repaired ${ }^{8-10}$ There is no consensus about which of the non-invasive methods or parameters as applied during follow-up have the best correlation with angiographically critical graft stenoses. Replacing angiographic evaluation of vein graft stenosis by duplex scanning would be advantageous." Graft occlusions may occur within the interval between the surveillance visit and the confirmative angiography." Avoiding angiograms during follow-up would not only result in less delay of the revisional procedure, it also would reduce the overall cost of graft surveillance programs. In this report the results are presented of a prospective cohort study with strictly standardized surveillance techniques, digital subtraction angiography (DSA) in a series of patients with infrainguinal venous bypasses. The objective of this study was to assess the accuracy of different surveillance parameters in comparison with angiography as a gold standard. For this analysis there will be a comparison on the basis of digital subtraction angiograms (DSA) performed in this series.

\section{PATIENTS AND METHODS}

Patients of three institutions following the same surveillance protocol were included in a prospective cohort surveillance study from June 1993 to September 1995. The study protocol, patient characteristics and the surveillance protocol are described in chapter 4 of this thesis.

\section{Surveillance parameters}

The following surveillance parameters were evaluated: (1) the peak systolic velocity at a normal mid-thigh graft segment (PSV-graft, cm/s), (2) the PSV at the severest stenotic site (PSV-max, cm/s), (3) the ratio of the PSV-max and the PSV at a nearby normal segment, proximally (or distally in case the graft stenosis was near the proximal anastomosis) of the stenosis (PSV-ratio), (4) the end-diastolic velocity at the 
site of the stenosis or in normal grafts at the narrowest segment of the bypass below the knee $(\mathrm{EDV}, \mathrm{cm} / \mathrm{s})$, (5) diameter reduction of the stenosis on the color image (DR $\%$ ), (6) the duplex measured flow in resting conditions at the mid-thigh graft (flow rest, $\mathrm{ml} / \mathrm{min}$ ), (7) flow at the mid-thigh graft during reactive hyperemia (flow $\mathrm{RH}$, $\mathrm{ml} / \mathrm{min}$ ), (8) ankle blood pressure at rest (ABP, mmHg), (9) ankle brachial blood pressure index $(\mathrm{ABI})$, and (10) ankle brachial blood pressure index at reactive hyperemia (ABI-RH).

\section{Study endpoints, data analysis}

All data were prospectively recorded and entered into a computerized database. The 10 surveillance parameters were correlated in a univariate analysis with angiographic ontcomes. This study is based on the DSA studies performed in the corresponding time. The criterion of an angiographic DR of $70 \%$ was selected as in previous studies this degree of lesion has been associated with a high risk of graft failure ${ }^{8-10,12}$ Angiograms were dichotomized into groups with a DR of 0 to $70 \%$ and a $\mathrm{DR}>70 \%$. An univariate comparison of both outcomes was performed with the use of the MannWhitney test. All non-invasive factors that demonstrated a significant difference ( $p$ $<0.05$ ) for the arteriographic categories in the univariate comparison were subjected to a multivariate analysis using logistic regression models. ${ }^{13}$ Variables with an independent correlation with the angiographic severity of stenoses were identified by backward elimination of the factors that contributed the least to the model. Receiver operating characteristic (ROC) curves were used to determine threshold values that provided the best separation in lesion categories. ${ }^{14}$

\section{RESULTS}

\section{Angiograms and graft revisions}

In the 300 patients 351 DSA studies were performed during follow-up. 182 DSA studies were performed for a change in surveillance parameters, most commonly a PSV-ratio $>2.0$, while 169 normal control DSA studies were performed in vein grafts without focal increase of PSV. Table I represents the indications and results of the 351 DSA studies performed. Excluded from the study were 22 angiograms: 8 patients had an angiogram but failed to appear for non-invasive examinations, 5 patients had a graft occlusion without identified stenosis and 9 patients had a complete occlusion of the run-off artery immediately distal of their bypass. All graft occlusions were accurately diagnosed by color imaging and absence of flow signals allowing determination of clinical management. For correlation of angiographic findings and listed surveillance parameters 329 DSA studlies were available. 
Table $1 . \quad$ The indications and results of the 351 digital subtraction angiograms performed.

\begin{tabular}{|c|c|c|c|}
\hline Results & $N$ & Indications & $n$ \\
\hline \multirow[t]{3}{*}{$\mathrm{DR}<70 \%$} & 197 & control & 161 \\
\hline & & strenosis on duplex & 33 \\
\hline & & low PSV-graft & 3 \\
\hline \multirow[t]{4}{*}{ DR $70 \%$ to $99 \%$} & 132 & stenosis on duplex & 123 \\
\hline & & low PSV-graft & 7 \\
\hline & & control DSA & 1 \\
\hline & & calinical symptoms & 1 \\
\hline Total graft occlusion & 2 & detected on duplex & 2 \\
\hline Partial graft occlusion & 3 & detected on duplex & 3 \\
\hline \multirow[t]{4}{*}{ Run-off artery occlusion } & 9 & detected on duplex & 2 \\
\hline & & Now PSV-graft & 3 \\
\hline & & clinical symptoms & 3 \\
\hline & & control DSA & 1 \\
\hline Miscellancous & 8 & no duplex to correlate & 8 \\
\hline
\end{tabular}

\section{Graft surveillance parameters}

All duplex and ABP derived parameters were correlated for groups with DSA confirmed lesions $<70 \%$ and $\geq 70 \%$ DR (Table II). Differences were observed for all parameters except for graft flow-RH and the significance was borderline for the resting graft flow. Despite statistical differences there was a considerable overlap of parameter outcomes in the DSA study groups. The best discrimination between grafts with and without significant stenoses was observed in PSV-max and PSV-ratio, which parameters are by definition strongly related with each other. There were no differences in the correllation of the PSV-ratio and the angiographic degree of stenosis between the three participating centers. The correlation of the PSV-ratio with the angiographic diameter reduction for the whole group is represented in Figure 1. Eight variables that demonstrated a significant difference in the univariate analysis, were subjected to a multivariate analysis by logistic regression. This resulted in a model containing two variables (PSV-ratio and ABP) with an independent association with the presence of a high-grade stenosis (Table III). 
Table II. Univariate correlation of duplex and ankle blood pressure derived parameters and DSA category with a DR $<70 \%$ and a $\mathrm{DR} \geq 70 \%$ stenosis.

\begin{tabular}{|c|c|c|c|c|c|}
\hline \multirow{2}{*}{$\begin{array}{l}\text { Paramerer } \\
\text { PSV-graf }\end{array}$} & \multicolumn{2}{|c|}{$\begin{array}{l}\text { DSA }<70 \% \\
\text { mean }(=S D)\end{array}$} & \multicolumn{2}{|c|}{$\begin{array}{c}D S A \geq 70 \% \\
\text { mean }( \pm S D)\end{array}$} & \multirow{2}{*}{$\begin{array}{c}\begin{array}{c}\text { Sigh. } \\
\text { 2-tailed }\end{array} \\
<0.001\end{array}$} \\
\hline & 60 & $(24)$ & 47 & $(23)$ & \\
\hline PSV-max & 147 & $(77)$ & 270 & $(108)$ & $<0.001$ \\
\hline PSV-ratio & 19 & (1) & 5.4 & $(2.6)$ & $<0.001$ \\
\hline EDV & 6 & (16) & 34 & (49) & $<0.00$ \\
\hline DR $\%$ & 24 & (23) & 54 & (19) & $<0.001$ \\
\hline Fliow rest & 190 & (203) & 164 & $(170)$ & 0.019 \\
\hline Flow RH & 268 & $(285)$ & 258 & $(295)$ & 0.164 \\
\hline ABP & 148 & $(40)$ & 120 & (39) & $<0.001$ \\
\hline $\mathrm{ABI}$ & 1.0 & $(0.3)$ & 0.8 & $(0.3)$ & $<0.001$ \\
\hline ABI-RH & 0.9 & $(0.2)$ & 0.7 & $(0.3)$ & $<0.001$ \\
\hline
\end{tabular}

For abbreviations see text.

Table III. Logistic regression model relating two variables to the probability of stenosis with $270 \%$. DR.

\begin{tabular}{lrrrr}
\hline Variable & \multicolumn{1}{c}{$\beta$} & SE & Wald test & $p$-kathe \\
\hline & & & & \\
PSV-ratio & 1.14 & 0.13 & 78.43 & $<0.001$ \\
ABP (minHg) & -0.01 & 0.005 & 8.28 & 0.004 \\
Constant & -2.17 & 0.77 & - & - \\
\hline
\end{tabular}

1. degrees of freedom $=1$.

As a next step $\mathbb{R O C - c u r v e s ~ w e r e ~ u s e d ~ t o ~ e v a l u a t e ~ t h e ~ s e n s i t i v i t y ~ a n d ~ s p e c i f i c i t y ~ o f ~ t h e ~}$ PSV-ratio alone and combined with the ABP to identify graft stenoses $\geq 70 \%$ DR. Of PSV-ratio alone a value of 3.0 provided the best outcome and was associated with a sensitivity of $80 \%$ and a specificity of $84 \%$. The sensitivity and specificity of the other PSV-ratios are presented in Table IV. Use of the combined parameter "PSV-ratio and $A B P^{\prime \prime}$ provided little improvement in sensitivity and specificity as compared with the PSV-ratio alone (Figure 2). Therefore it was concluded that to distinguish angiographic 
llesions of $\geq 70 \%$ from less severely stenosed grafts use of the PSV-ratio only is sufficient. In an additional multivariate analysis in graft subgroups it was demonstrated that of the 8 surveillance parameters the PSV-ratio had the best correlation with the presence of high-grade lesions in in-situ or ectopic nom-reversed grafts, in reversed grafts, in femoropopliteal grafts, and in infrapopliteal grafts.

Figure 1. The correlation of the PSV-ratio with the angiographic diameter reduction.

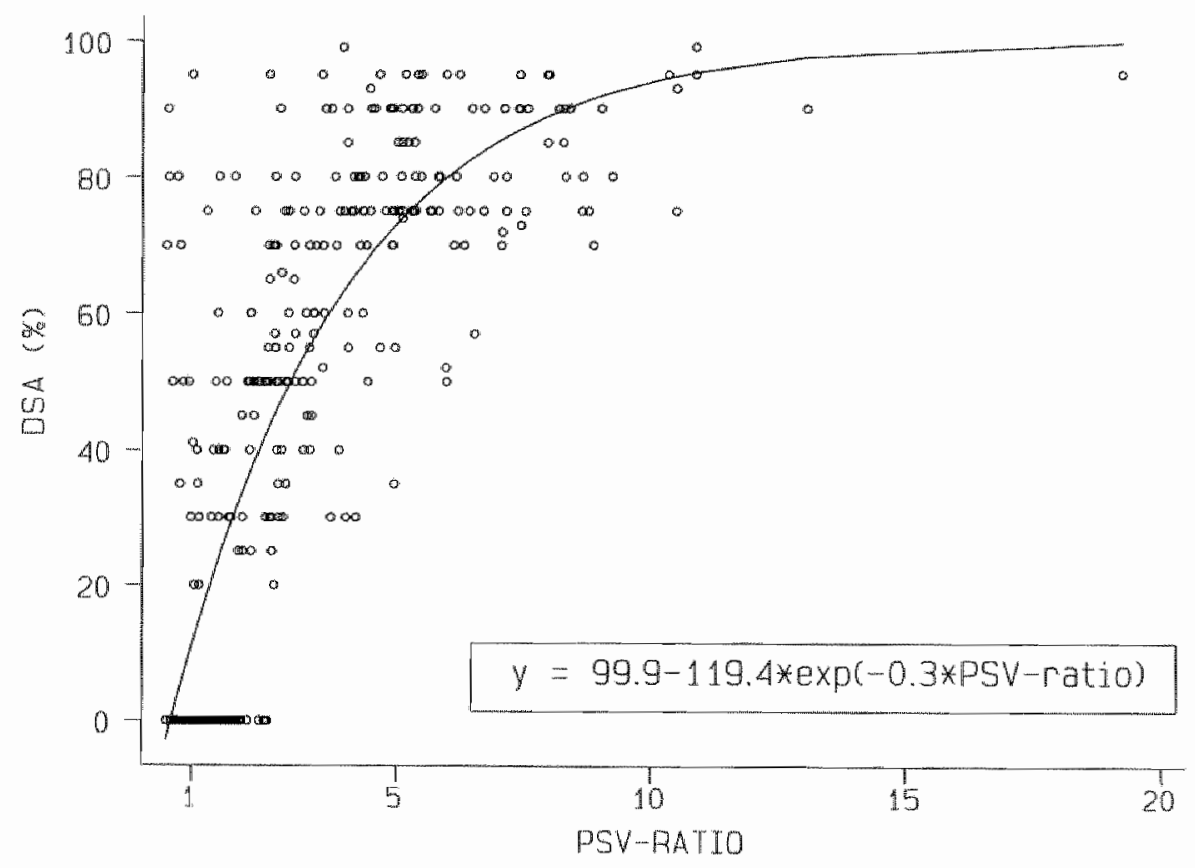


Table IV. The sensitivity and specificity of the PSV-ratio in identifying vein graft stenosis with an angiographic dianneter reduction $\geq 70 \%$.

PSW-ratio Sensitivity Specificity

\begin{tabular}{lll}
\hline 2.00 & $88 \%$ & $61 \%$ \\
$\geq 2.50$ & $86 \%$ & $74 \%$ \\
$\geq 2.75$ & $82 \%$ & $81 \%$ \\
2300 & $80 \%$ & $84 \%$ \\
$\geq 3.25$ & $78 \%$ & $88 \%$ \\
$\geq 3.50$ & $75 \%$ & $92 \%$ \\
$\geq 4.00$ & $70 \%$ & $94 \%$ \\
\hline
\end{tabular}

Figure 2. Receiver operating characteristic (ROC) curves of the peak systolic velocity (PSV)-ratio and of the combined parameter PSV-ratio and ankle blood pressure (ABP).

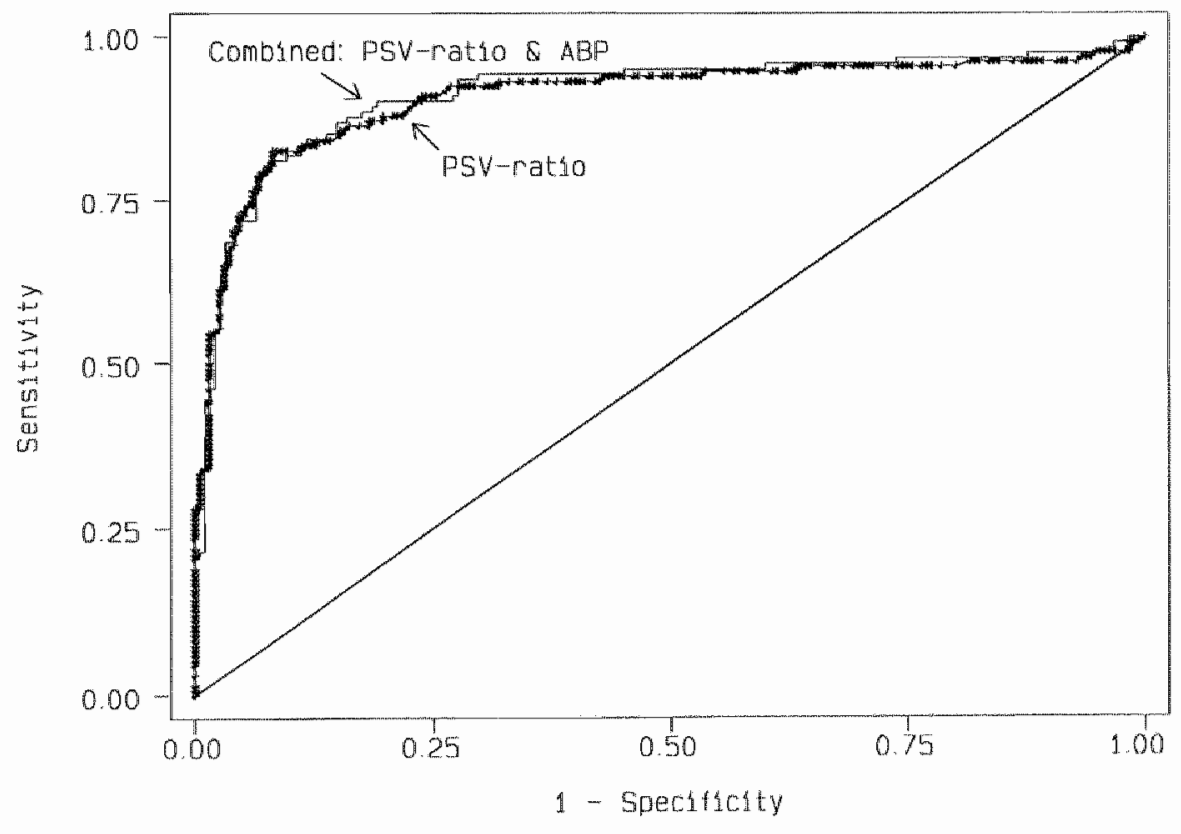




\section{DISCUSSION}

It is generally accepted that the follow-up of patients with infrainguinal vein grafts should be directed toward the identification of failing grafts. At this stage relatively minor procedures can often avert impending graft failure. ${ }^{15,16}$ For the identification of grafts with stenotic lesions ankle blood pressure measurements and more recently duplex and color-flow duplex examinations have been used., ${ }^{4,1720}$ With duplex examinations low-velocity and high-velocity criteria can be distinguished. The former criterion requires only measurements of the peak systolic velocity (PSV) at a fixed point at mid-graft level (PSV-graft). It has been observed, however, that this criterion had a low sensitivity for focal lesions and that low PSV-graft values (low flow state grafts) were frequently caused by run-off or inflow disease..$^{12,21,22}$ At present the most commonly used color-flow duplex examination includes tracing of the entire graft, identification of sites with flow disturbance, and measurement of the PSV at the stenosis. Absolute PSV values as well as the ratio of the PSV at the stenosis and a normal adjacent arterial segment are used. Threshold values for the PSV-ratio vary in the literature from 1.5 to $3.5^{4,10,19,21,23,24}$ In the present study the correlation of a set of 10 duplex and ankle blood pressure (ABP) derived parameters, all reported in the literature were determined. In addition to the parameters described above reactive hyperemia tests combined with ABI and duplex derived volume flow measurements were included. ${ }^{25,26}$ End-diastolic velocities were recorded as well. This variable has been indicated as a correlant with high-grade graft lesions, a relationship of which the hemodynamic background was recently described by Papanicolaou et al ${ }^{27}$ Correlation of all parameters and the degree of stenosis as measured on the angiograms was performed. All angiographic diameter reductions and surveillance variables were obtained in a strictly uniform fashion in the three institutions that participated in this carefully monitored prospective study. The surveillance parameters were determined by different duplex apparatus by a group of 9 vascular laboratory technicians. Nevertheless, correlation of key surveillance and angiographic variables resulted in comparable outcomes in the institutions. Using multivariate analysis the PSV-ratio and the $A B P$ appeared the most important independent predictor of a significant stenosis, overtoning all other parameters. The combination of these two variables however provided hardly a better sensitivity and specificity to identify graft stenosis $\geq 70 \%$ than the PSV-ratio alone. A PSV-ratio $>3.0$ was a reasonable indicator of the presence of a stenosis $>70 \%$ DR, with a sensitivity of $80 \%$ an a specificity of $84 \%$. In conclusion, of many surveillance parameters the PSV-ratio has the best correlation with the angiographic degree of stenosis. 


\section{REFERENCES}

1. Szilagyi DE, Elliot JP, Hageman JH, Smith RF, Sallolmo CA. Biological tate of autologous wein implants as arterial substitutes. Ann Surg 1973;178:232-246.

2. Moady $\mathrm{P}$, deCossart LM, Douglas HM, Harris PL. Asymptomatic strictures in fomoropopliteal vein grafts. Eur J Vasc Surg 1989:3:389-392.

3. Taylor LM, Edwards JM, Porter JM. Present status of reversed vein bypass grafting. Five-year results of a modem series. J Vasc Surg 1990;11:193-206.

4. Grigg MJ. Nicolaides AN, Wolfe JHN. Femorodistal vein bypass graft stenosis. Br J Surg $1988 ; 75: 737-740$.

5. Bandyk DF, Schmitt DD, Seabrook GR, Adams MB, Towne JB. Monitoring functional patency of in situ saphenous vein bypasses: the impact of at surveillance protocol and clective revision. J Vasc Surg 1989:9:286-296.

6. Mills JL, Harris JE, Taylor LM, Beckett WC, Porter JM. The importance of routine surveillance of distal bypass grafts with duplex scaming: A study of 379 reversed vein grafts. J Vasc Surg $1990 ; 12: 379-389$.

7. Bergamini TM, George SM Jr, Massey HT, Henke PK, Klamer TW, Lambert GE, Miller FB, Garrison RN, Richardson JD. Intensive surveillance of femoropopliteal-tibial autogenous vein bypasses improves long-term graft patency and limb salvage. Ann Surg 1995; 221:507-516.

8. Harris PL, Moody AP. The management of vein bypass strictures. In: Grecnhalgh RM, Hollier LM, ed. The maintenance of arterial reconstruction. London: WB Saunders, 1991 ; 169. 178.

9. Idu MM, Blankensteyn JD, de Gier P, Truyen E, Buth J. Impact of a color-flow duplex surveillance program on infrainguinal wein graft patency. A five-year experience. J Vase Surg $1993,17: 42-53$.

10. Caps MT, Cantwell-Gab K, Bergelin RO, Strandness DE. Vein graft lesions: Time of onset and rate of progression. J Vasc Surg 1995; 22:466-475.

11. Moneta GL, Yeager RA, Antonovic R, Hall LD, Caster JD, Cummings CA, Porter JM. Accuracy of lower extremity arterial duplex mapping. J Vasc Surg 1992; 15:275-284.

12. Sladen JG, Reid JDS, Cooperberg PL, Harrison PB, Maxwell TM, Rings MO, Sanders LD. Color flow duplex screening of infrainguinal grafts combining low- and high-velocity criteria. Am J Surg 1989;158:107-112.

13. Cox DR. The analysis of binary data. 1970, Methuan, London.

14. McNeil BJ, Keeler E, Adelstein AJ. A primer on certain elements on medicall decision making. $N$ Engl J Med 1975;293211-215.

15. Veith FI, Weiser RK, Gupta SK, Ascer E, Scher LA, Samson RH, White-Flores SA, Sprayregen $S$. Diagnosis and management of failling lower extremity arterial reconstructions prior to graft occlusion. J Cardiovase Surg 1984:25:381-384.

16. Cohen JR, Mannick JA, Couch NP, Whittemore AD. Recognition and managenent of impending wein-graft failure. Arch Surg 1986;121:758-759.

17. Moody P, Gould DA, Harris PL, Vein graft suryeillance improves patency in femoropopliteal bypass. Eur II Vase Surg 1990;4:117-121.

18. Berkowitz $\mathrm{H}$, Hobbs Ch, Roberts $\mathrm{B}$, Friedman $\mathrm{D}$, Oleaga $\mathrm{J}$, Ring $\mathrm{E}$. Valuc of routinc vascular laboratory studies to identify vein graft stenoses. Surgery 1981;90:971.979.

19. Lundell $A$, Lindblad B, Bergqvist D, Hansen F. Femoropopliteal-crural graft patency is improved by an intensive surveillance program: A prospective randomized study. J Vase Surg 1995;21 2634. 
20. Taylor PR, Wolfe JHN, Tyrrell MR, Mansfield AO, Nicolaides AN, Houston RN. Graft stenosis: Justification for 1-year surveillance. Br I Surg 1990;77:1125-1128.

21. Mattos MA, van Bemmelen PS, Hodgson KJ, Ramsey DE, Barkmeier LD, Sumner DS. Does correction of stenosis identified with color duplex scanning improve infrainguinal graft patency? J Vase Surg 1993; 17:54-66.

22. Cossman DV, Ellison JE, Wagner WH, Carroll RM, Treiman RL, Foran RF, Levin PM, Cohen JL. Comparison of contrast arteriography to arterial mapping with color-flow duplex imaging in the lowner extremities. IV Vasc Surg 1989;10:522-529.

23. Bandyk DF. Essentials of graft surveillance. Semin Vasc Surg 1993;6:92-102.

24. Mohan CR, Hoballah II, Schueppert MT, Sharp WJ. Kresowilk TF, Miller EV, Corson JD. Should all in situ saphenous wein bypasses undergo permanent duplex scanning? Arch Surg $1995 ; 130: 483-488$

25. Wyatt MG, Muir RM, Tennant WG, Scott DJA, Baird RN, Horrocks M. Duplex-derived volume flow: a comparison of two tests in the assessment of "at risk" femoro-distal grafts. Br I Surg $1990 ; 77: 346$

26. Kupinski AM, Stone MS, DePalma H. Is reactive hyperemia a reliable indicator of impending bypass failure. J Vasc Technol 1990;14:163-165.

27. Papanicolaou G, Beacli KW, Zierker RE, Strandness DE. Systolic flow limitations in stenotic lower extrenity vein grafts. J Vase Surg 1996;23;394-400. 
Chapter 6

\section{Vein graft surveillance: Is graft revision without arteriography justified and what criteria should be used?}

Part of this chapter has been published as:

Id MM, Buth J, Hop WCJ. Cuypers Ph, van de Pavoord EDWM, Tordoir JMH.

Vein graft surveillance: Is graft revision without arteriography justified and what criteria should be used? J Vasc Surg 1998:27:399-413. 


\section{INTRODUCTION}

Autogenous vein grafts provide the best conduit for bypass treatment of femoropopliteal and femorocrural occlusive disease. However, successful patency is threatened by the development of stenosis in $20 \%$ to $30 \%$. Frequent non-invasive examinations followed by elective revision of failing, but non-occluded grafts has become common practice, which is believed to salvage conduits as well as limbs. ${ }^{4-7}$ The presence of a significant arteriographic stenosis is a reliable predictor of graft failure unless the lesion is repaired ${ }^{810}$ Replacing angiographic evaluation of vein graft stenosis by duplex scanning would be advantageous. "Iraft occlusions may occur within the interval between the surveillance visit and the confirmative angiography. ${ }^{9}$ Avoiding angiograms during follow-up would not only result in less delay of the revisional procedure, it also would reduce the overall cost of graft surveillance programs. This approach assumes that surveillance examinations have a high positive predictive value (PPV) and negative predictive value (NPV) to avoid unnecessary interventions and in order not to miss a large proportion of patients with failing grafts. There is no agreement on what outcomes of surveillance measurements are reliable indicators of expected graft failure or obvious need for intervention. In this report the results are presented of a prospective cohort study with strictly standardized surveillance techniques and digital subtraction angiography (DSA) in a series of patients with infrainguinal venous bypasses and a fixed protocol with regard to interventions for documented severe lesions in the graft or the adjacent arterial segments. The objective of this study was to examine correlations of parameters with the fate of the graft during follow-up. In addition the threshold level for the angiographic degree of stenosis to distinguish grafts with a high and a low risk of failure was validated.

\section{PATIINTS AND METHODS}

The study protocol, patient characteristics and the surveillance protocol has been described in chapter 4 of this thesis.

\section{Study endpoints, data analysis}

The occurrence of primary events in relation with the presence of a time-dependent risk factor, such as a PSV-ratio above a predefined level, can be determined by a cumulative hazard analysis and transient state method with Kaplan-Meier curves. ${ }^{13,14}$ With this method the cumulative primary patency rate is assessed in two groups of observations. Group $A$ involves all patients as long as a surveillance measurement remains within speciffed limits, for example a PSV-ratio <3.0 (Figure 2). In this group 
the observation time starts at the time of the procedure ( $T=0)$. If the PSV-ratio exceeds 3.0 a patient ceases to be part of group $A$ and is further represented in group B. Patients are part of group B from the moment their surveillance parameters have exceeded the threshold value $(T=0)$. In both groups any patient reaching an endpoint of primary patency (primary event, i.e. a graft revision or occlusion) is represented as a drop in patency. Basically, this method, which was described by Mantel and Byar in 1974 , allows a comparison of patency rates between patients with and without a timedependent risk factor. ${ }^{13,15}$ A perfect predictive value of a risk factor regarding the occurrence of events is represented by a $100 \%$ patency in group A and a zero patency in group B. As our previous study (chapter 5) has shown that the PSV-ratio is the best non-invasive parameter to grade vein graft stenosis, the PSV-ratio is used to define the groups.

\section{RESULTS}

\section{Graft revisions and patencies}

The median follow-up period was 20 months (range 1 to 40 ). Localization of revised stenoses, types of revision and numbers of graft occlusions are summarized in Table $I$. Interventions were performed in $84(28 \%)$ of the grafts and the total number of revisions including multiple stenoses and recurrences was 144. Primary graft occlusions were diagnosed in 31 cases. In 16 the occlusion occurred without obvious cause, but in 15 patients the presence of a high-grade lesion was known. In the latter cases there usually was a delay to revise the graft and sometimes refusal or inability of the patient to return for the procedure. The 2-year primary patency determined by standard Kaplan-Meier life table analysis was $52 \%$ (SE 3\%), and the secondary patency was 79\% (SE 3\%) for the total study group (Appendix A, see also notes to the Table I). 
Table 1. Graft stenoses, revisions and occlusions in 300 patients during follow-up.

\section{Nomber}

Localization of revised stenoses (DSA) $(n=144$ stenoses)*

Inflow artery

Proximal anastomosis $\quad 30$

Graft above the knee $\quad 27$

Graft at the knee $\quad 18$

Graft bellow the knee 17

Distal anastomosis $\quad 39$

Run-off aurtery $\quad 12$

Type of first time revision ( $\mathrm{n}=84$ revisions) *

$\begin{array}{ll}\text { PTA (atherectomy, stent) } & 35 \\ \text { Patchplasty } & 17 \\ \text { Intcrposition graft } & 14 \\ \text { Jump graft } & 18\end{array}$

Simultaneous revision of multiple stenoses (no. of revisions) 13

Subsequent revisions (no. of patients)

2 revisions

3 revisions

8

Graft occlusions as primary event $(\mathrm{n}=31 \text { occlusions })^{* *}$

Occlusion without obvious cause 16

Occlusion with known high-grade stenosis $\quad 15$

4he total number of 144 revised stenoses involved the first time revisions $(n=84)$, simultaneous revisions of multiple stenoses $(n=13)$, and subsequent 2 nd and 3 rd revisions $(n=47)$; * The total of 31 occlusions, together with 84 first time revisions constituted the patients with a primary event $(\mathrm{n}=$ 115) in the regular life table primary graft patency analysis for 300 patients (Appendix A). In 12 paticnts the occlusion was later thati 6 months after the last surveillance examinations rendering any relation uncertain. Therefore these were not considered as a primary event in the transient state life table leaving 103 primary event patients for analysis (Appendix $B, C$ and $D$ ). 


\section{$70 \%$ Angiographic diameter reduction as a risk factor of occlusion}

A validation was performed whether graft stenoses of $70 \%$ angiographic dianeter reduction or greater imposed the greatest risk for occlusion. Therefore the secondary patency rate was compared for grafts with different degrees of stenosis, using the transient state method. In this analysis the onset of the observation periods coincided with the time of the arteriogram determining the classification. In the Kaplan-Meier curve using the transient state method the secondary cumulative patency is represented of grafts with a stenosis of $\angle 50 \%, 50 \%$ to $70 \%, \geq 70 \%$ DR (Figure 1). The 18-month secondary patency rate in patients with $\angle 50 \%$ DR angiographic stenoses was $99 \%$, in stenoses of $50 \%$ to $70 \%$ DR the patency was $87 \%$, and in stenoses $\geq 70 \%$ it was $78 \%$ (Appendix B). It should be noted that as per protocol patients with a degree of stenosis less than $70 \%$ were not revised in this study, whereas all patients with a $70 \%$ lesion or greater had a graft revision planned. The validity of a $70 \%$ DR threshold vallue as discriminator between grafts with a high risk of failure or otherwise was clearly supported by this observation.

Figure 1. Secondary patency rates represented by Kaplan-Meier curves of patients with a angiographic stenosis $<50 \%, 50 \%$ to $70 \%$ and $\geq 70 \%$.

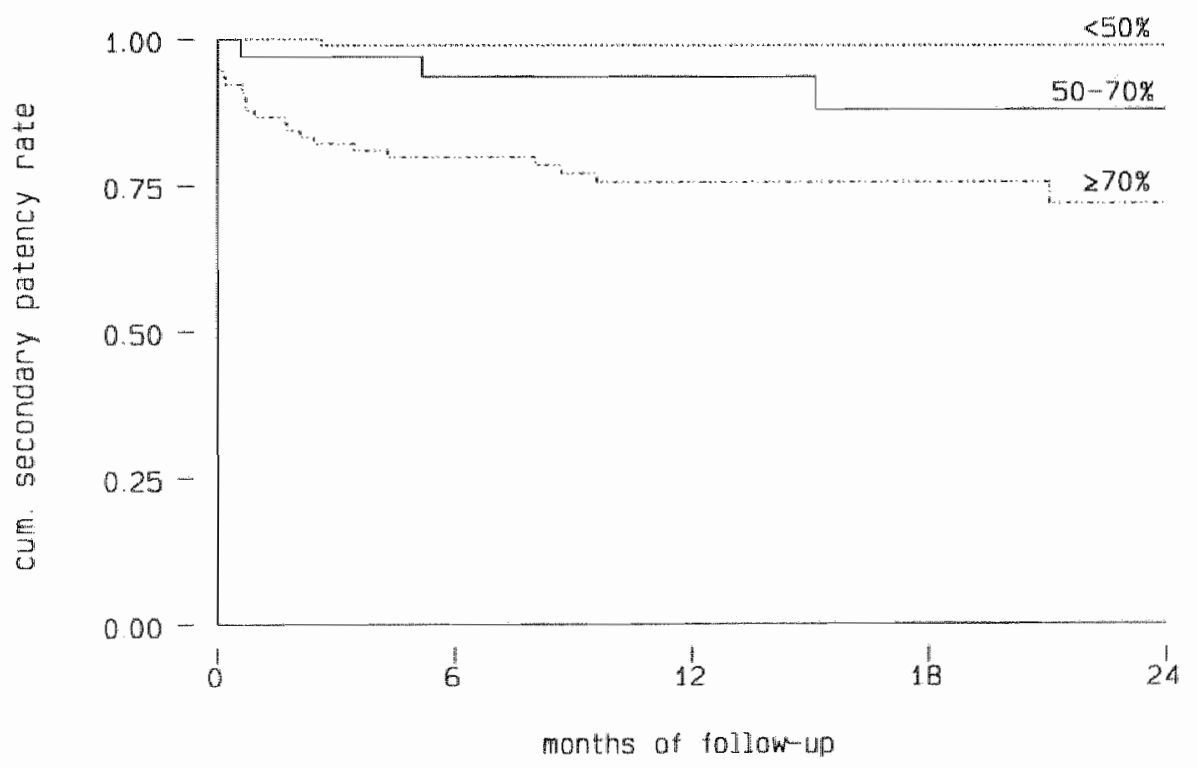




\section{Graft patency relative to surveillance parameters}

During the total follow-up-period 103 of $300(34 \%)$ patients reached a primary patency endpoint (84 revisions and 19 primary occlusions within 6 months of the last surveillance duplex examination). Redo interventions were not included for this analysis. (See for a detailed account of graft revisions and occlusions in life table analysis the notes to Table I). From the investigation described in chapter five of this thesis, it appeared that the PSV-ratio was the best indicator of a high-grade graft stenosis. Therefore a series of cutoff values of this parameter was correlated with the occurrence of primary clinical events by cumulative hazard analysis with transient state method and Kaplan-Meier graphs. It is of note that in this study the only indication for revision of a graft lesion was a stenosis of $70 \%$ DR or greater at angiography.

Figure 2. Primary patency rates represented by Kaplan-Meiar curves of patients with a PSV-ratio $<3.0$ (group A) and patients with a PSV-ratio $>3.0$ (group B). In group $A . T=0$ coincided with the time of operation and in group $\mathbb{B}, \mathbb{T}=0$ coincided with the first time the observed PSV-ratio was 23.0. Curve of group A depicts the patency as long as the PSV-ratio has not exceded 3.0 (transient state method).

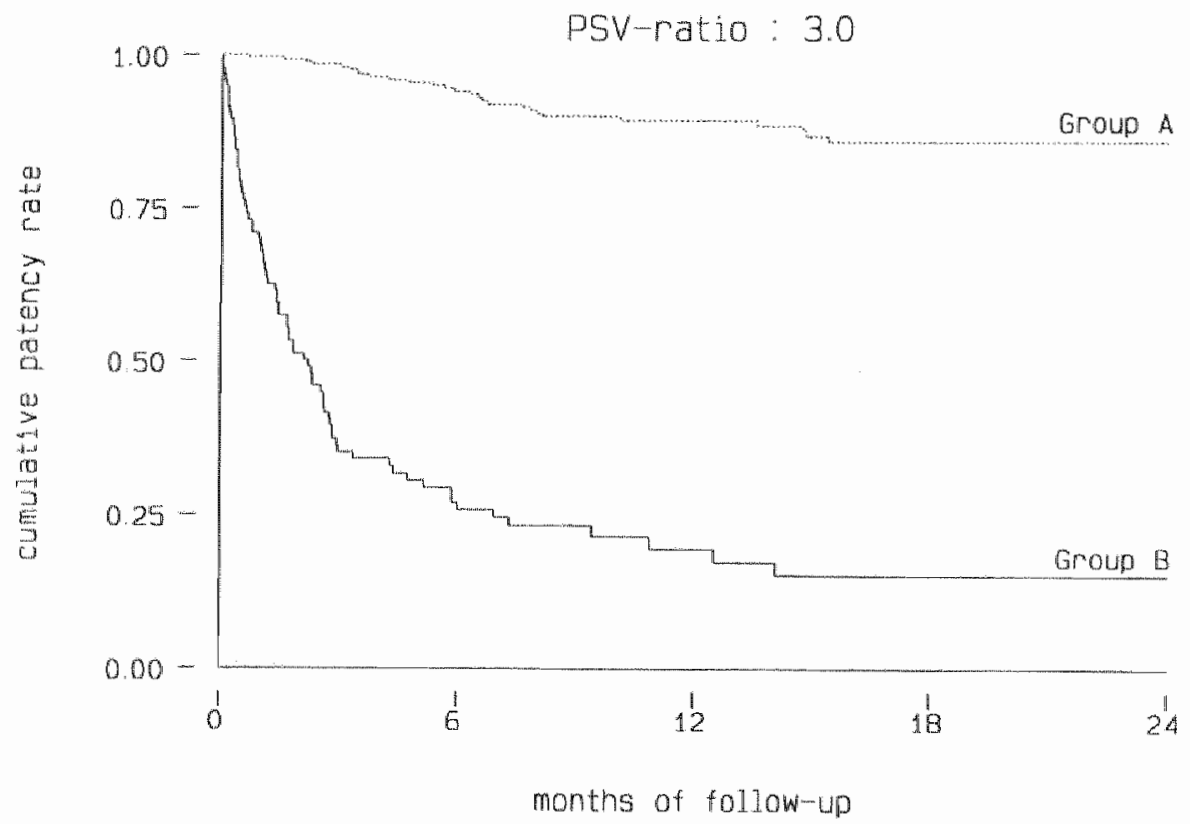


The first assessment was for a PSV-ratio of 3.0. Of the 300 patients in the study population 264 initially had a PSV-ratio $<3.0$ and therefore belonged to group A, while 97 patients, either had a PSV-ratio $\geq 3.0$ at their initial survellance examination or at a later time during following-up to be part of group B (Figure 2 and Appendix $\mathrm{C}$ ). The 18-month primary patency of group $A$ was $86 \%$ and in group $B$ it was $15 \%$. Alternatively these findings may be expressed as negative predictive value (NPV), represented by the primary patency in group $A$, and positive predictive value (PPV), which is equal to 100 minus the primary patency in group B. Thus the 18 -month NPV of a PSV-ratio 3.0 is $86 \%$ and the PPV is $85 \%$. This represents a just moderate agreement with the actual clinical course. Primary events in spite of a PSV-ratio <3.0 occurred in 27 patients and in 21 patients events failed to appear although they had a PSV-ratio $>3.0$. For clinical application an algorithm based on a single surveillance parameter does not appear sufficiently accurate to replace prerevision angiography.

In 23 patients the PSV-ratio progressed from $<2.5$ to $\geq 4.0$ during the surveillance period. The PPV and NPV of PSV-ratios 2.5, 3.0, and 4.0 are represented together in Figure 3 . None of these criteria was entirely correct in indicating whether a primary event would or would not occur, i.e. the PPV and NPV were less than $100 \%$ (Table II). A PSV-ratio of 2.5 was associated with a 18 -month patency in group A of $89 \%$, whereas a PSV-ratio of 4.0 had a patency in group B of 7\%. If the best predictive values were combined by using the PSV-ratios 2.5 and 4.0 in one algorithm a better correlation with the occurrence of primary events was obtained than with one cutoff value (Figure 4 and Appendix D). The accuracy of this criterion was represented by a NPV of $89 \%$ and a PPV of $93 \%$ (Table II). If used as an algorithm the observation of a PSV-ratio $<2.5$ may be interpreted as a graft not at risk and graft surveillance should be continued. If a PSV-ratio $\geq 4.0$ is recorded a graft is at high risk for failure and a revision should be scheduled without the need of a pretreatment angiogram. Cases with PSV-ratios between 2.5 and 4.0 represent an intermediate risk group and an angiographic study is indicated to verify whether a stenosis of $70 \%$ DR or greater is present. 
Table I. Prediction of endpoints of primary patency by different PSV-ratios.

$\begin{array}{lcc}\text { PSV-ratio } & \text { NPV } & \text { PPV } \\ \text { threshold walue } & \% & 0 \%\end{array}$

25

89

79

3.0

86

85

4.0

80

93

NPV is negative predictive value; PPV is positive predictive value; indicated NPV and PPV represent 18-month walue.

Figure 3. Primary patency rates represented by Kaplan-Meier curves of patients with PSV-ratios less (upper curves) or greater (lower curves) than 2.5,3.0 and 4.0 (transient state method).

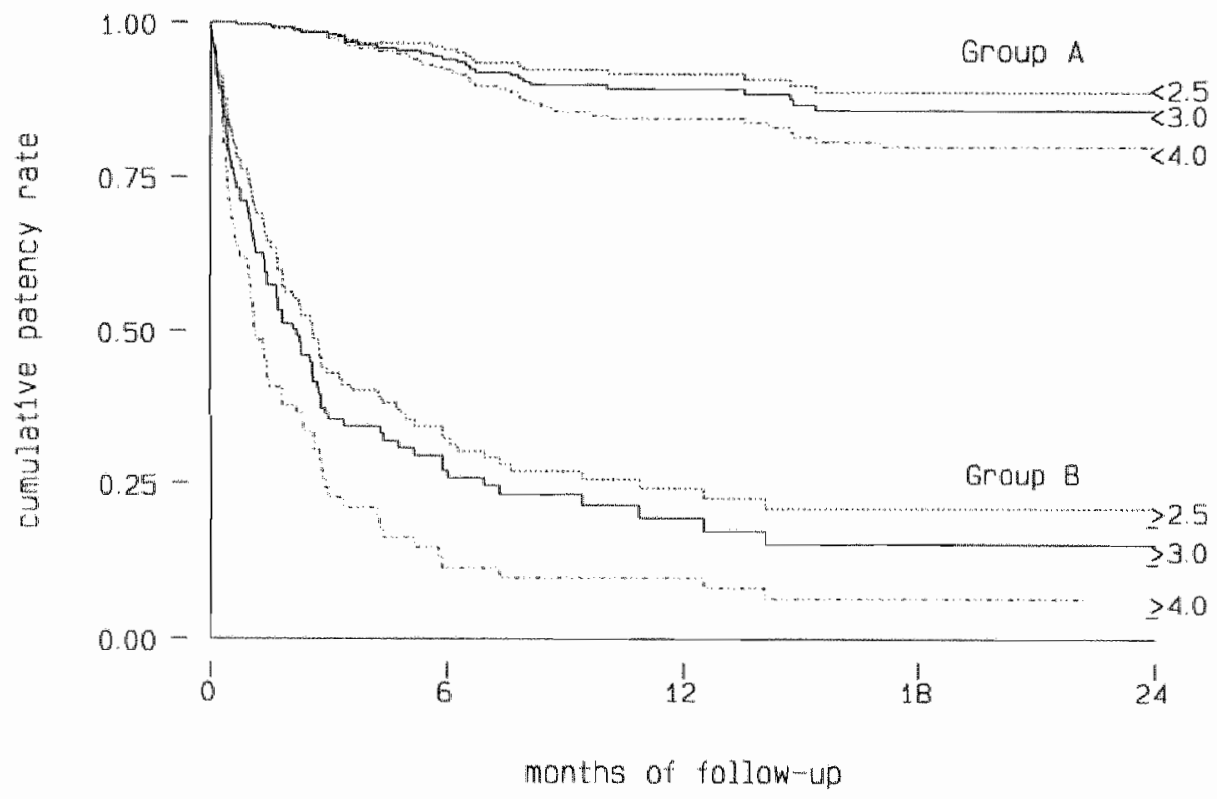


Figure 4. Primary patency rates represented by Kaplan-Meier curves of patients with a PSV-ratio $\ll 2.5$ (group A) and patients with a PSV-ratio 24.0 (group B) (transient state method).

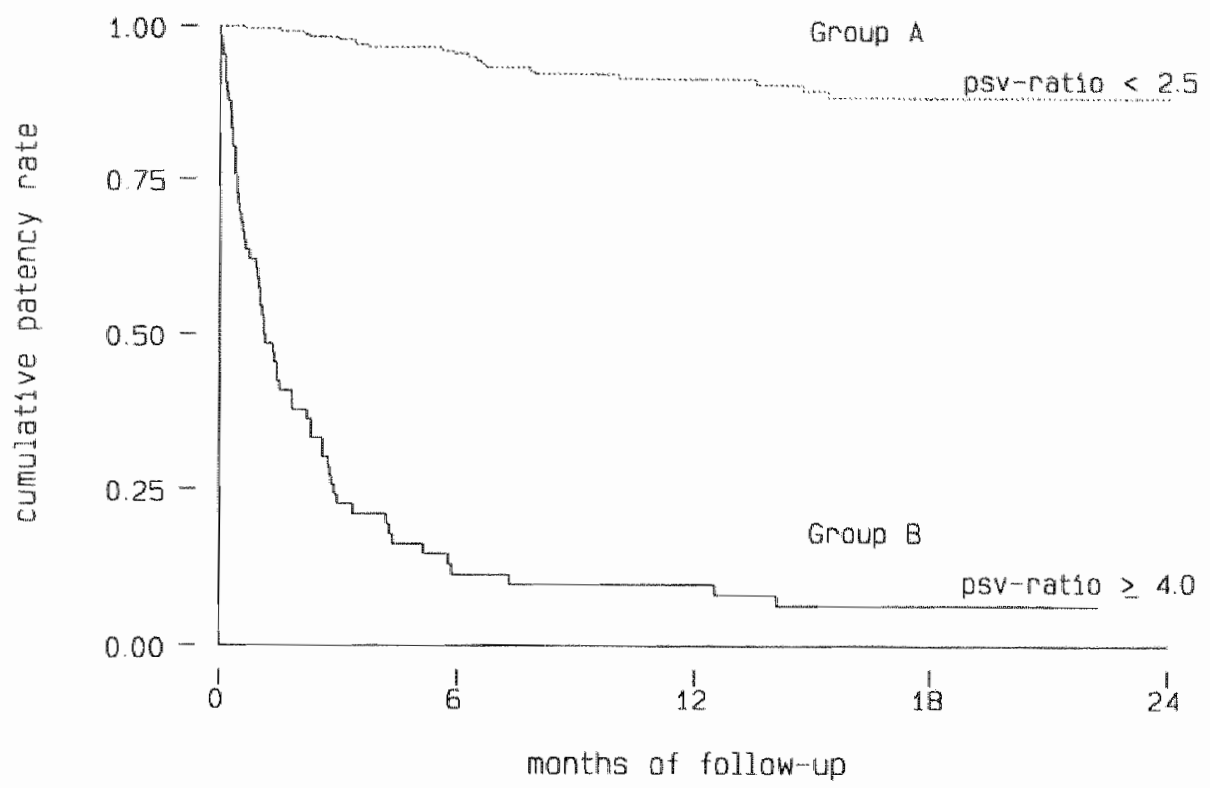

In Table III the consequences of the two-parameter algorithm are summarized. If this algorithm had been applied 5 patients with a PSV-ratio $\geq 4.0$ would have undergone an intervention, but had in fact no revision as their angiographic stenoses were less than $70 \%$ (false positive observations). The angiographic stenoses in these 5 patients had a DR of $60 \%, 55 \%, 55 \%, 45 \%$ and $40 \%$. Had interventions been performed on the basis of duplex findings these may be considered unnecessary treatment. 20 Grafts had a primary event in spite of a PSV-ratio $<2.5$ (false negative observation). This category included a sudden graft occlusion without obvious cause in 8 , and revision of highgrade lesions on the basis of angiograms in 12 patients. These latter patients, although they had no signs of a localized velocity increase, still had lesions in the graft, the inflow or the run-off. Angiograms were requested because of a "low flow state" (PSVgraft $\angle 45 \mathrm{~cm} / \mathrm{s}$ ) in 7 patients, return of severe symptoms in 4 patients, and in only one patient the stenosis was detected coincidentally on a protocol-directed control DSA. Moreover, in the two-parameter algorithm 64 DSAs were required in patients with a PSV ratio between 2.5 and 4.0 (Table III), while a graft revision without angiography would have been scheduled in 61 patients (true positive diagnosis, i.e. patients with a 
PSV $>4.0$ and terminal event - Appendix D). This implied a $49 \%$ reduction in DSAs compared with a policy of requesting an angiogram in any patient with a PSV-ratio of 2.5 or greater. On the basis of these observations it was concluded that a rwoparameter algorithm could be practically applied in a surveillance program to limit the use of angiographic studies.

Table III. Revisions, conserwative approaches and angiograms with two surveillance algorithms.

$\begin{array}{ccc}\text { Diagnosiss } & \text { Consequences if algorithm } & \text { Two-parameteralgorithm Single-parameter algorithm } \\ \text { wass applied } & \text { no. of patients } & \text { mo. of patients }\end{array}$

\begin{tabular}{|c|c|c|c|}
\hline False positive & $\begin{array}{l}\text { Unnecessary revisions } \\
\text { of lesions with DR }<70 \%\end{array}$ & 5 & 21 \\
\hline False negative & $\begin{array}{l}\text { Acute occlusion or } \\
\text { no treatment in spite } \\
\text { of lesions with DR } 270 \%\end{array}$ & 20 & 27 \\
\hline Uncertain & DSAs required & 64 & 0 \\
\hline
\end{tabular}

\section{DISCUSSION}

It is generally accepted that the follow-up of patients with infrainguinal vein grafts should be directed toward the identification of failing grafts. At this stage relatively minor procedures can often avert impending graft failure. ${ }^{16,17}$ Most vascular surgeons still consider intraarterial DSA mandatory before petforming an intervention on a graft stenosis detected by non-invasive surveillance methods. However, there is some variation in the severity of the stenosis that is considered to represent a considerable risk of graft failure. A DR of $50 \%$ has been proposed as the critical level by several authors, 4 while others believe a lesion with a $70 \%$ DR to indicate a failing vein graft. $2,8-10,20,21$ It may be assumed that these differences at least in part, account for the variations in the critical PSV-ratios that have been reported in the literature. In the 
present study the angiographic DR was measured by radiologists blinded for the findings at duplex examinations. In a validating assessment we found that a $70 \%$ threshold correlated significantly with graft failure. Non-revised stenoses of $50 \%$ to $70 \%$ had a better patency than stenoses of $70 \%$ DR or greater, which fell in the patient category with revisions.

Angiography to confirm a suspected asymptomatic graft lesion is cumbersome and it causes delay of effective treatment, which may result in graft failure if the stenosis is high-grade. In the this prospective study 15 vein grafts with known presence of a stenosis failed during the interval between the last surveillance visit and the intervention. In addition, angiographic evaluation adds considerably to the cost of follow-up, making surveillance programs less cost-effective. A surveillance schedule by which angiography is avoided altogether would be ideal. ${ }^{11}$ It was examined whether a single-parameter surveillance algorithm based on a PSV-ratio of 3.0 provided such a scheme. However a NPV of $86 \%$ (27 patients false negative) and a PPV of $85 \%$ (21 patients false positive) was not satisfactory. To compare the positive and negative predictive values of different surveillance parameters an appropriate statistical technique was used. ${ }^{15}$ This statistic is very similar to the logrank statistics, except that group membership is not fixed along time. With cumulative hazard analysis and transient state method using Kaplan-Meier life tables PSV-ratios above a threshold value were considered risk factors and their agreement with actual occurrence of primary events was assessed. In this analysis patients with normal PSV-ratios serve as a pseudo-control group.

Although not all grafts with a high-grade stenosis occlude and some without lesions still fail, no surveillance algorithm will be perfect. Requirements for an algorithm in our view should include as a first priority the avoidance of unnecessary interventions, which corresponds with a high PPV. The second priority is to miss as few severe stenoses as possible, corresponding with a high NPV. The final requirement is to avoid angiograms or at least a portion of it. The two-parameter algorithm outlined in this study distinguished three risk classes for graft failure requiring different management strategies. The algorithm implicated a conservative approach in patients with a PSV-ratio $<2.5$, a revision without preceding angiography with PSV-ratios $>4.0$, and a DSA in patients with PSV-ratios between 2.5 and 4.0. The non-invasive diagnostic criteria when correlated with the actual angiographic findings had a PPV of $93 \%$ and an NPV of $89 \%$. Of the 5 patients with a false positive diagnosis 3 had a stenosis greater than $50 \%$ at the time of angiography, which perhaps might have justified a revision. Of the 20 patients with a false negative diagnosis 8 had a graft occlusion without any prior duplex or angiographic evidence of a stenotic lesion. We assume that these grafts could not have been salvaged by a revision. Of the other patients only one had a completely missed stenosis, while the other patients had either "low flow state" grafts or recurrent clinical symptoms. Although these variables are 
poor indicators of graft stenoses in statistical models they do have clinical significance and should be considered combined with high velocity criteria. ${ }^{23,24}$ Thus one could argue that with a structured non-invasive diagnostic protocol and a reduced use of angiograms in a series of 300 patients only 2 with a false positive diagnosis and 1 with a false negative diagnosis would have received inappropriate treatment, which seems an acceptably low rate.

The two-parameter algorithm needs to be evaluated in a future prospective study. Other aspects than the degree of stenosis that may influence planning of interventions are length and multiplicity of lesions. Both features can be studied adequately by modern color-flow duplex equipment. Lesions of less than one centimeter can be scheduled for percutaneous angioplasty and longer lesions for operative repair either by patch angioplasty or by interposition grafting. ${ }^{25}$

In conclusion, an algorithm using two cutoff levels to delineate patient groups with a low, an intermediate and a high risk of graft failure seems applicable. Clinical management can be based on this decision tree. The number of angiograms during follow-up in patients with a significantly increased PSV-ratio can be reduced considerably as these need to be requested in the intermediate group only. 


\section{REFERENCES}

1. Szilagyi DE, Elliot JP, Hageman JH, Smith RF, Sallolmo CA. Biological fate of antologous vein implants as arterial substitutes. Ann Surg 1973;178:232-246.

2. Moody P, deCossart LM, Douglas HM, Harris PL. Asymptomatic strictures in femoropopliteal vein grafts. Eur J Vasc Surg 1989;3:389-392.

3. Taylor LM, Edwards JM, Porter JM. Present status of reversed vein bypass grafting. Five-year results of a modern series. J Vasc Surg 1990;11:193-206.

4. Grigg MJ, Nicolaides AN, Wolfe JHN. Femorodistal vein bypass graft stenosis. Br J Surg 1988;75:737-740.

5. Bandyk DF, Schmitt DD, Seabrook GR, Adams MB, Towne JB. Monitoring functional patency of in situ saphenous vein bypasses: the impact of a surveillance protocol and elective revision. J Vasc Surg 1989;9:286-296.

6. Mills JL, Harris JE, Taylor LM, Beckett WC, Porter JM. The importance of routine surveillance of distal bypass grafts with duplex scanning: A study of 379 reversed vein grafts. IVasc Surg 1990;12:379-389.

7. Bergamini TM, George SM Jr, Massey HT, Henke PK, Klamer TW, Lambert GE, Miller FB, Garrison RN, Richardson JD. Intensive surveillance of femoropopliteal-tibial autogenous vein bypasses improves long-term graft patency and limb salvage. Ann Surg 1995; 221:507-516.

8. Harris PL, Moody AP. The management of vein bypass strictures. In. Greenhalgh RM, Hollier $\mathrm{LM}_{3}$ ed. The maintenance of arterial reconstruction. London: WB Saunders, $1991,169-178$.

9. Idu MM, Blankensteyn JD, de Gier P, Truyen E, Buth I. Impact of a color-flow duplex surveillance program on infrainguinal vein graft patency. A five-year experience. I Vasc Surg $1993 ; 17: 42-53$

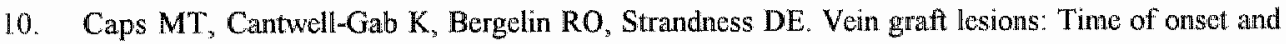
rate of progression. J Vasc Surg 1995; 22:466-475.

11. Moneta GL, Yeager RA, Antonovic R, Hall LD, Caster JD, Cummings CA, Porter JM. Accuracy of lower extremity arterial duplex mapping. IJ Vase Surg 1992;15:275-284.

12. Rutherford RB, Flanigan DP, Gupta $S K$, et al. Suggested standards for reports dealing with lower extremity ischemia. J Vasc Surg 1986,4:80-94.

13. Mantel N, Byar DP. Evaluation of response-time data involving transient states: an illustration using heart-transplant data. J Am Stat Assoc 1974;69:81-86

14. Simon $\mathrm{R}$, Mukuch RW. A non-parametric graphical representation of the relationship between survival and the occurrence of an event: application to responder versus non-reversed bias. Statis Medic 1984;3:35-44.

15. Hop WCJ, van Buuren HR. A method to evaluate changes in prognostic status during follow-up. Comp Biol Med 1989;19:181-188.

16 Veith EJ, Weiser RK, Gupta SK, Ascer E, Scher LA, Samson RH, White-Flores SA, Sprayregen $S$. Diagnosis and management of failing lower extremity arterial reconstructions prior to graft occlusion. J Cardiovase Surg 1984;25:381-384.

17. Cohen JR, Mannick JA, Couch NP, Whittemore AD. Recognition and management of impending. vein-graft failure. Arch Surg 1986;121:758-769.

18. Lundell $A$, Lindblad B, Bergqvist $D$, Hansen F. Femoropopliteal-crural graft patency is improved by an intensive surveillance program: A prospective randomized study. I Vasc Surg 1995;21:2634 . 
19. Matros MA, van Bemmelan PS, Hodgson KJ, Ramsey DE, Barkmeier LD, Sumner DS. Does correction of steniosis identified with color duplex scanning improve infrainguinal graft patency? I Vase Surg 1993,17:54-66.

20. Sladen JG, Reid JDS, Cooperberg PL, Harrison PB, Maxwell TM. Rings MO, Sanders LD. Color flow duplex screening of infrainguinal grafts combining low- and high-welocity criteria Am J Surg $1989 ; 158: 107-112$.

21. Bandyk DF. Essentials of graft surveillance. Semin Vasc Surg 1993;692-102.

22. Davies AH, Magee TR, Temant SGW, Lamont PM, Baird RN, Horrocks M. Criteria for identification of the "at risk infrainguinal bypass graft. Eur J Vasc Surg 1994;8:315-319.

23. Passman MA, Moneta GL, Nehler MR, Taylor LM Jr, Edwards JM, Yeager RA, Mc Connel

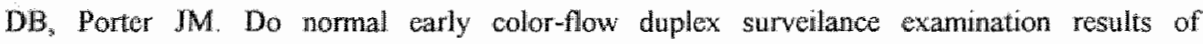
infrainguinal wein grafts preclude the need for late graft revision. J Vasc Surg 1995;22:476-484.

24. Taylor PR. Tyrrell MR, Crofton M, Bassan B, Grigg M, Wolfe JHN, Mansfield AO, Micolaides. AN. Colour flow imaging in the detection of femoro-distal graft and native artery stenosis. Improved criteria. Eur J Vasc Surg 1992;2:232-236.

25. Sanchez $L A$, Suggs WD, Marin ML, Panetta TF, Wengerter KR, Veith FJ. Is percutaneous balloon angioplasty appropriate in the treatment of graft and anastomotic lesions responsible for failing vein bypasses? Am J Surg 1994; 168:97-101 
Appendir A. Life table primary and secondary graft patency analysis for 300 infrainguinal vein grafts.

\begin{tabular}{|c|c|c|c|c|c|c|}
\hline $\begin{array}{c}\text { Interwal } \\
\text { (mo) }\end{array}$ & $\begin{array}{c}\text { No grafis } \\
\text { at risk }\end{array}$ & $\begin{array}{c}\text { No. grafts } \\
\text { with terminal } \\
\text { events }\end{array}$ & $\begin{array}{l}\text { No grafis } \\
\text { withdrown }\end{array}$ & $\begin{array}{c}\text { Interval } \\
\text { patency rare }\end{array}$ & $\begin{array}{c}\text { Cunv. } \\
\text { patency rate }\end{array}$ & $S E$ \\
\hline
\end{tabular}

Primary patency

$\begin{array}{rrrrrrr}0-3 & 300 & 36 & 3 & 0.88 & 0.88 & 0.02 \\ 3-6 & 261 & 35 & 10 & 0.86 & 0.76 & 0.02 \\ 6-9 & 216 & 26 & 10 & 0.88 & 0.67 & 0.03 \\ 9-12 & 180 & 5 & 25 & 0.97 & 0.65 & 0.03 \\ 12-15 & 150 & 7 & 37 & 0.95 & 0.61 & 0.03 \\ 15-18 & 106 & 3 & 10 & 0.97 & 0.59 & 0.03 \\ 18-21 & 93 & 1 & 18 & 0.99 & 0.59 & 0.03 \\ 21-24 & 74 & 1 & 13 & 0.99 & 0.58 & 0.03 \\ 24-27 & 60 & 0 & 13 & 1.00 & 0.58 & 0.03\end{array}$

Secondary parency

$\begin{array}{rrrrrrr}0-3 & 300 & 2 & 5 & 0.99 & 0.99 & 0.01 \\ 3-6 & 293 & 16 & 11 & 0.94 & 0.94 & 0.01 \\ 6-9 & 266 & 6 & 12 & 0.98 & 0.92 & 0.02 \\ 9-12 & 248 & 2 & 36 & 0.99 & 0.91 & 0.02 \\ 12-15 & 210 & 3 & 44 & 0.99 & 0.89 & 0.02 \\ 15-18 & 163 & 2 & 17 & 1.00 & 0.88 & 0.02 \\ 18-21 & 144 & 0 & 24 & 0.99 & 0.87 & 0.02 \\ 21-24 & 120 & 1 & 22 & 0.99 & 0.86 & 0.02 \\ 24-27 & 97 & 1 & 25 & 0.97 & 0.84 & 0.02\end{array}$


Appendix B. Life tablic secondary graft patency analysis for 300 patients with infrainguinal vein grafts rellative to the angiographic diameter reduction (transient state method).

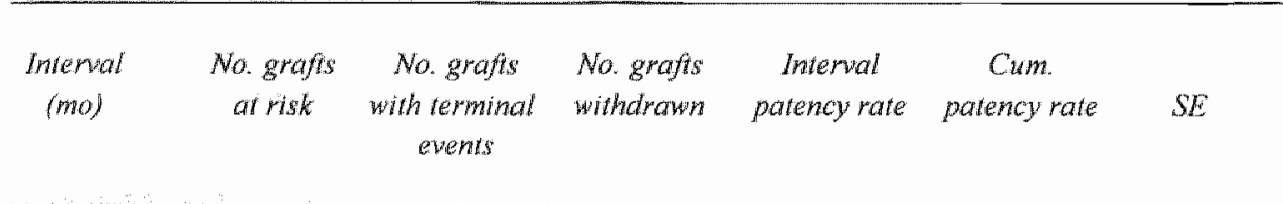

Angiographic $D R<50 \%$

$\begin{array}{rrrrrrr}0-3 & 117 & 1 & 17 & 0.99 & 0.99 & 0.01 \\ 3-6 & 99 & 0 & 26 & 1.00 & 0.99 & 0.01 \\ 6-9 & 67 & 0 & 6 & 1.00 & 0.99 & 0.01 \\ 9-12 & 67 & 0 & 20 & 1.00 & 0.99 & 0.01 \\ 12-15 & 47 & 0 & 4 & 1.00 & 0.99 & 0.01 \\ 15-18 & 43 & 0 & 16 & 1.00 & 0.99 & 0.01 \\ 18-21 & 27 & 0 & 7 & 1.00 & 0.99 & 0.01 \\ 21-24 & 20 & 0 & 9 & 1.00 & 0.99 & 0.01\end{array}$

Angiographic DR $50 \%$ ro $70 \%$

$\begin{array}{rrrrrrr}0-3 & 36 & 1 & 3 & 0.97 & 0.97 & 0.03 \\ 3-6 & 32 & 1 & 4 & 0.97 & 0.94 & 0.04 \\ 6-9 & 27 & 0 & 4 & 1.00 & 0.94 & 0.04 \\ 9-12 & 23 & 0 & 6 & 1.00 & 0.94 & 0.04 \\ 12-15 & 17 & 0 & 0 & 1.00 & 0.94 & 0.04 \\ 15-18 & 17 & 1 & 5 & 0.93 & 0.87 & 0.07 \\ 18-21 & 11 & 0 & 3 & 1.00 & 0.87 & 0.07 \\ 21-24 & 8 & 0 & 3 & 1.00 & 0.87 & 0.07\end{array}$

Angrographic DR $>70 \%$

$\begin{array}{rrrrrrr}0-3 & 88 & 13 & 5 & 0.85 & 0.85 & 0.04 \\ 3-6 & 70 & 2 & 2 & 0.97 & 0.82 & 0.04 \\ 6-9 & 66 & 2 & 9 & 0.97 & 0.80 & 0.04 \\ 9-12 & 55 & 1 & 6 & 0.98 & 0.78 & 0.05 \\ 12-15 & 48 & 0 & 11 & 11.00 & 0.78 & 0.05 \\ 15-18 & 37 & 0 & 10 & 1.00 & 0.78 & 0.05 \\ 18-21 & 27 & 0 & 6 & 1.00 & 0.78 & 0.05 \\ 21-24 & 21 & 1 & 3 & 0.95 & 0.74 & 0.06\end{array}$


Appendix C. Life table primary graft patency analysis for 300 patients with infraingunal vein grafts relatiwe to obsenved PSV-ratio $<3.0$ or $\geq 3.0$ (transient state method).

\begin{tabular}{|c|c|c|c|c|c|c|}
\hline $\begin{array}{c}\text { Intenwal } \\
\text { (mo) }\end{array}$ & $\begin{array}{c}\text { No. grafts } \\
\text { at risk }\end{array}$ & $\begin{array}{c}\text { No. grafts } \\
\text { wh the remmal } \\
\text { events }\end{array}$ & $\begin{array}{l}\text { No. grafts: } \\
\text { withditawn }\end{array}$ & $\begin{array}{c}\text { Intephat } \\
\text { patency rate }\end{array}$ & $\begin{array}{c}\text { Cum } \\
\text { porency rare }\end{array}$ & $\$ B$ \\
\hline
\end{tabular}

Group A: PSV $<3.0$

$\begin{array}{rrrrrrr}0-3 & 264 & 5 & 10 & 0.98 & 0.98 & 0.01 \\ 3-6 & 249 & 9 & 45 & 0.96 & 0.94 & 0.02 \\ 6-9 & 195 & 8 & 21 & 0.96 & 0.90 & 0.02 \\ 9-12 & 166 & 1 & 31 & 0.99 & 0.89 & 0.02 \\ 12-15 & 134 & 3 & 34 & 0.97 & 0.87 & 0.02 \\ 15-18 & 97 & 1 & 11 & 0.99 & 0.86 & 0.03 \\ 18-21 & 85 & 0 & 17 & 1.00 & 0.86 & 0.03 \\ 21-24 & 68 & 0 & 13 & 1.00 & 0.86 & 0.03\end{array}$

Group B: PST $\geq 3.0$

$\begin{array}{rrrrrrr}0-3 & 97 & 62 & 2 & 0.35 & 0.35 & 0.05 \\ 3-6 & 33 & 7 & 3 & 0.78 & 0.27 & 0.05 \\ 6-9 & 23 & 3 & 5 & 0.85 & 0.23 & 0.04 \\ 9-12 & 15 & 2 & 4 & 0.85 & 0.20 & 0.04 \\ 12-15 & 9 & 2 & 0 & 0.78 & 0.15 & 0.04 \\ 15-18 & 7 & 0 & 0 & 1.00 & 0.15 & 0.04 \\ 18-211 & 7 & 0 & 3 & 1.00 & 0.15 & 0.04 \\ 21-24 & 4 & 0 & 3 & 1.00 & 0.15 & 0.04\end{array}$


Appendix D. Life table primary graft patency analysis for 300 patients with infrainguinal wein grafts relatiwe to observed PSV-ratio (mansient state method).

\begin{tabular}{|c|c|c|c|c|c|c|}
\hline $\begin{array}{c}\text { Interval } \\
\text { (mo) }\end{array}$ & $\begin{array}{c}\text { No grafts } \\
\text { at risk }\end{array}$ & $\begin{array}{c}\text { No grafts } \\
\text { whith terminal } \\
\text { evenss }\end{array}$ & $\begin{array}{l}\text { No. grafts } \\
\text { withdrawit }\end{array}$ & $\begin{array}{c}\text { Interval } \\
\text { patency rate }\end{array}$ & $\begin{array}{c}\text { Cum } \\
\text { patency rare }\end{array}$ & $S E$ \\
\hline
\end{tabular}

PSV-ratio: 2.5

Grotup A (PSW-ratio <2.5)

$\begin{array}{rrrrrrr}0-3 & 252 & 5 & 8 & 0.98 & 0.98 & 0.01 \\ 3-6 & 239 & 5 & 46 & 0.98 & 0.96 & 0.01 \\ 6-9 & 188 & 6 & 22 & 0.97 & 0.92 & 0.02 \\ 9-12 & 160 & 1 & 31 & 0.99 & 0.92 & 0.02 \\ 12-15 & 128 & 2 & 36 & 0.98 & 0.90 & 0.02 \\ 15-18 & 90 & 1 & 10 & 0.99 & 0.89 & 0.02 \\ 18-21 & 79 & 0 & 12 & 1.00 & 0.89 & 0.02 \\ 21-24 & 64 & 0 & 12 & 1.00 & 0.89 & 0.02\end{array}$

Group B (PSW-ratio 22.5)

$\begin{array}{rrrrrrr}0-3 & 113 & 63 & 4 & 0.43 & 0.43 & 0.05 \\ 3-6 & 46 & 11 & 3 & 0.75 & 0.33 & 0.05 \\ 6-9 & 32 & 5 & 5 & 0.83 & 0.27 & 0.04 \\ 9-12 & 22 & 2 & 4 & 0.90 & 0.24 & 0.04 \\ 12-15 & 16 & 2 & 2 & 0.87 & 0.21 & 0.04 \\ 15-18 & 12 & 0 & 0 & 1.00 & 0.21 & 0.04 \\ 18-21 & 12 & 0 & 4 & 1.00 & 0.21 & 0.04 \\ 21-24 & 8 & 0 & 6 & 1.00 & 0.21 & 0.04\end{array}$


Appendix D - continued. Life table primary graft patency analysis for 300 patients with infrainguinal vein grafts relative to observed PSV-ratio (transient state method).

PSF-ratio: 4.0

Group A (PSV ratio <4.0)

$\begin{array}{rrrrrrr}0-3 & 273 & 7 & 10 & 0.97 & 0.97 & 0.01 \\ 3-6 & 256 & 12 & 32 & 0.95 & 0.93 & 0.02 \\ 6-9 & 212 & 15 & 17 & 0.93 & 0.86 & 0.02 \\ 9-12 & 180 & 2 & 30 & 0.99 & 0.85 & 0.02 \\ 12-15 & 148 & 4 & 411 & 0.97 & 0.82 & 0.03 \\ 15-18 & 103 & 2 & 11 & 0.98 & 0.80 & 0.03 \\ 18-21 & 90 & 0 & 18 & 1.00 & 0.80 & 0.03 \\ 21-24 & 72 & 0 & 13 & 1.00 & 0.80 & 0.03\end{array}$

Group B (PSV-ratio $\geq 4.0)$

$\begin{array}{rrrrrrr}0-3 & 66 & 51 & 0 & 0.23 & 0.23 & 0.05 \\ 3-6 & 15 & 7 & 1 & 0.52 & 0.12 & 0.04 \\ 6-9 & 7 & 1 & 0 & 0.86 & 0.10 & 0.04 \\ 9-12 & 6 & 0 & 0 & 1.00 & 0.10 & 0.04 \\ 12-15 & 6 & 2 & 0 & 0.67 & 0.07 & 0.03 \\ 15-18 & 4 & 0 & 1 & 1.00 & 0.07 & 0.03 \\ 18-21 & 3 & 0 & 2 & 1.00 & 0.07 & 0.03 \\ 2 \mathrm{~J}-24 & 1 & 0 & 1 & 1.00 & 0.07 & 0.03\end{array}$


Chapter 7

\section{Economizing vein graft surveillance programs}

This chapter was modified from:

Idu MM, Buth J, Hop WCJ, Cuypers Ph, van de Pavoordt EDWM, Tordoir JMH. Economizing vein graft surveillance programs.

Eur J Vasc Endovasc Surg 1998 (in press) 


\section{INTRODUCTION}

Intrinsic vein graft stenosis is a major threat to infrainguinal bypasses. In approximately $30 \%$ of all vein grafts stenotic lesions will develop, due to intima hyperplasia, remodeling or fibrosis..$^{1-3}$ Vein graft surveillance has been shown to be an effective method of identifying stenotic lesions, thus allowing repair of these defects before graft thrombosis occurrs. However, the necessity for repetitive duplex testing during a longer period of time makes considerable demands on patients and vascular laboratories. Better utilisation of resources may be obtained by restricting surveillance testing to patients at high-risk of developing graft stenosis. Several patient factors, operative technical and vein graft related factors have been identified as being associated with an increased risk of stenosis development or graft occlusion., ${ }^{4,5}$ Recently it has been suggested that most stenotic lesions are the result of progression of residual vein graft lesions or platelet deposits already present at the time of operation. In this view it might be possible that patients with grafts that have a high risk of developing significant lesions during follow-up can be identified by the first postoperative duplex scanning soon after the bypass procedure. ${ }^{6-8}$

The large majority of graft lesions develop within the first 12 months, and many authors agree therefore, that surveillance may be discontimued at that time. ${ }^{4,9}$ Others have stressed that serial examinations can not be dispensed after 1 year and graft surveillance should be continued for longer periods, if not for the duration of the patient's life. ${ }^{10-13}$ An alternative way of reducing expenses and workload involved with stenosis detection may be to limit the duration of the surveillance period and thus the number of examinations.

In this study the effectiveness of these two strategies targeted to a reduction of duplex surveillance testing was investigated. The first strategy attempted to reduce the number of patients for continued surveillance by identifying grafts with a higher risk of significant stenosis, indicated by the presence of early duplex abnormalities. In the second strategy the effect of reducing the duration of the surveillance program in the overall patient group, with regard to the number of graft stenoses that would be missed, was examined.

\section{PATIENTS AND METHODS}

The study protocol, patient characteristics and the surveillance protocol has been described in chapter 4 of this thesis.

To assess the optimal duration of graft surveillance, a regularly measured PSVratio was used as an indicator of "significant graft stenosis" (PSV-ratio 22.5). An "event causing stenosis" was present if a stenosis required a revision. All revised 
lesions had a diameter reduction greater than $70 \%$ on angiography. Moreover, stenoses that had caused a graft occlusion before a revision was undertaken, were defined "event causing stenoses". A stenosis was classified a "de novo stenosis" if the previous PSV-ratio was $<2.0$, and a "progressive stenosis" if it was $>2.0$ at a previous visit and increased by 1.0 or more.

Intraoperative or predischarge duplex entire graft scanning was infrequently performed during the study. Therefore these data were not included in the analysis. Early duplex scanning was defined as the first complete graft examination, which was after 4 to 6 weeks.

\section{Definitions and data-analysis}

A primary event was defined as revision of a stenotic but patent graft, or graft occlusion. Primary graft failure was used as the study endpoint for a patient. The efficacy of initial surveillance measurements as predictor for the development of severe graft stenosis was represented by the primary patency. For all patients the occurrence of primary events and the time interval between the event and the initial duplex scanning was recorded. Kaplan-Meier curves were used with grafts categorised according to the PSV-ratio at the first surveillance visit. Receiver operating characteristic (ROC) curves were used to assess the sensitivity and specificity of the initial PSV-ratio for predicting primary graft failure in the first year. The analysis was performed using SPSS 7.0 for Windows statistical software.

\section{RESULTS}

\section{Initial duplex examination}

Most $(74 \%)$ of the initial duplex examinations were performed within 6 weeks after the operation, and $94 \%$ were performed within three months after graft implantation. Kaplan-Meier curves of the primary patency were constructed for patient groups with an initial PSV-ratio $<1.5$ (group 1), 1.5 to 2.0 (group 2), 2.0 to 2.5 (group 3), 2.5 to 3.0 (group 4), and $\geq 3.0$ (group 5) (Figure 1). Patients with "early lesions" groups 2 and 3 did not show a different course of their primary patency than patients with "normal grafts" (group 1) (primary patencies at 12 months of $63 \%, 73 \%$, and $71 \%$ respectively). The primary patency of group 4 and 5 at 12 months was $38 \%$ and $21 \%$ respectively. Group 4 differed from groups 1 to $3(p$, respectively, $<0.001,0.07,0.01)$, and group 5 differed from groups 1 to $3(p$, all $<0.001)$.

The clinical applicability of the initial PSV-ratio to discriminate grafts with a high and a low probability of encountering a primary event during the first year was further assessed by a ROC-analysis, represented in Figure 2 . There was no distinct threshold value for this separation, as the best combination of sensitivity and 
specificity was still rather low ( $54 \%$ and $75 \%$ respectively). The secondary 12 -month patency for groups with a PSV-ratio $\geq 3.0$ and $<3.0$ was $80 \%$ and $92 \%$ respectively $(p$ $=0.01)$.

Figure 1. Primary patency rates represented by Kaplan-Meier curves of patient groups according to the initial PSV-ratio: group 1 (PSV-ratio <1.5), group 2 (PSV-ratio 1.5 to 2.0), group 3 (PSV-ratio 2.0 to 2.5), group 4 (PSV-ratio 2.5 to 3.0 ), and group 5 (PSV-ratio 23.0). On the abscissa $T=0$ represents the time of the initial duplex examination.

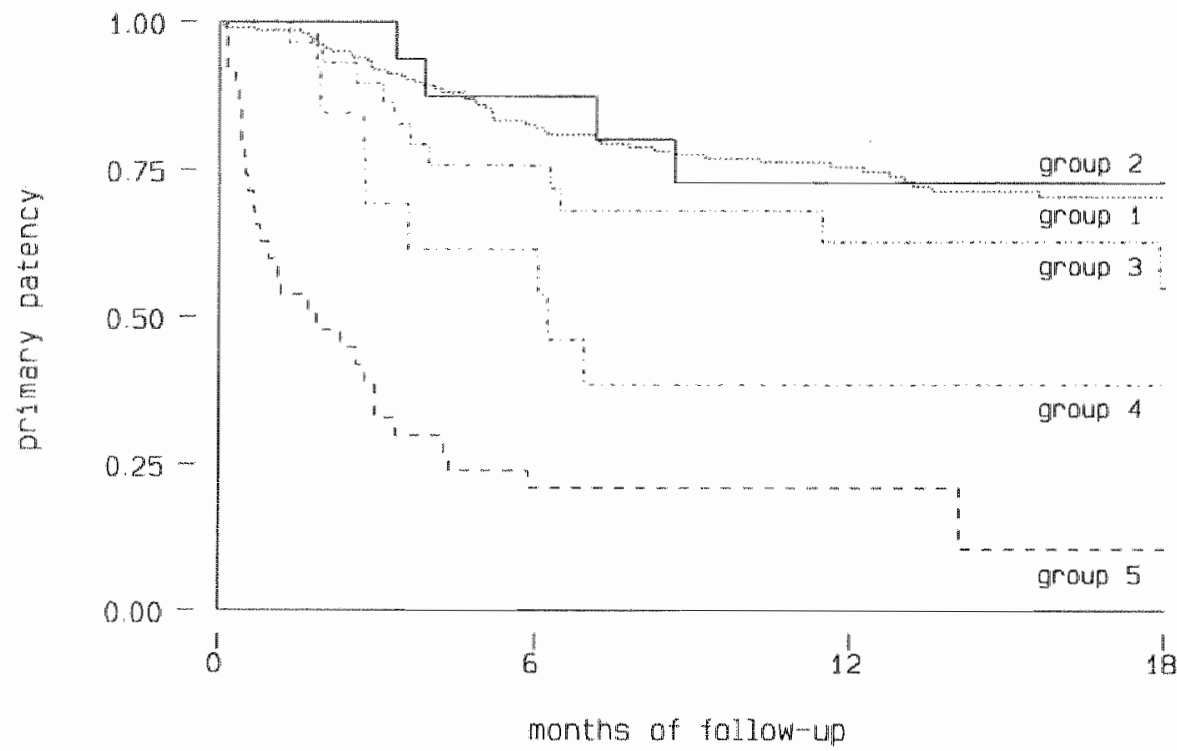

\section{Grafts at risk}

Initial PSV-ratio Omonths 6 months 12 months 18 months

$\begin{array}{llrrrr}51.5 & \text { (group 1) } & 203 & 149 & 95 & 65 \\ 1.5 \text { to } 2.0 & \text { (group 2) } & 30 & 20 & 11 & 7 \\ 2.0 \text { to } 2.5 \text { (group 3) } & 18 & 13 & 7 & 5 \\ 2.5 \text { to } 3.0 & \text { (group 4) } & 14 & 8 & 3 & 3 \\ >3.0 & \text { (group 5) } & 35 & 7 & 3 & 1\end{array}$


Figure 2. Receiver operating characteristic (ROC) curves of the initial peak systolic velocity ratio (PSV-ratio) and its correlation with primary events during the first year.

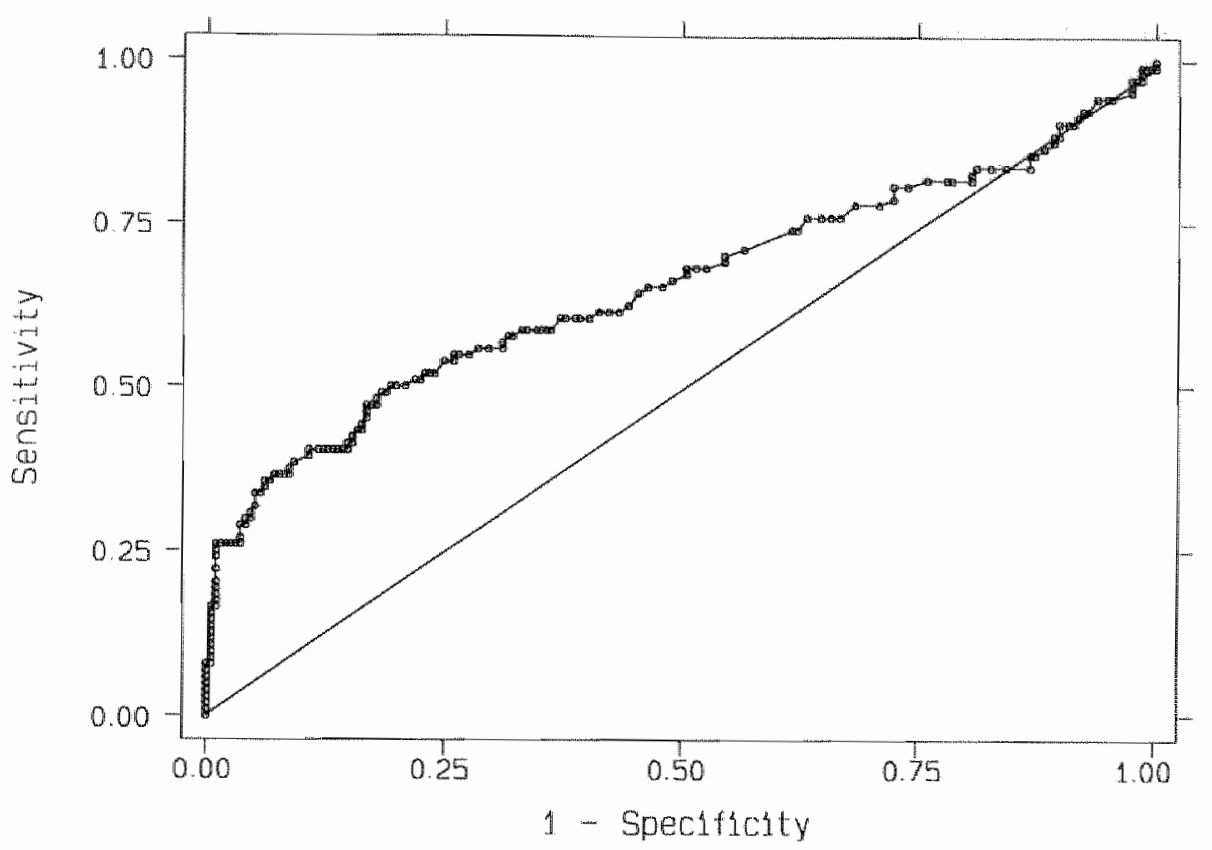

\section{Duration of surveillance period}

For all. grafts in this study (including grafts that were enrolled again after their first or second revision) the time of onset of "significant stenosis" (PSV-ratio 22.5 ), and of "event causing de novo stenosis" (revision or occlusion) is represented in Table 1. Of all performed surveillance examinations the interval rates of significant de novo stenosis were $17 \%, 14 \%$, and $10 \%$ at 6 weeks, 3 months, and 6 months. At the 9 th and 12 th month interval the incidence was considerably lower, $5 \%$ and $5 \%$ respectively. Event causing de nowo stenosis occurred at the 6th week, 3rd month and 6 th month interval in $8 \%, 8 \%$, and $8 \%$. At the 9 th and 12 th month interval this type of stenosis occurred in $4 \%$ and $7 \%$ of the grafts. Of the total of 111 event causing stenosis that occurred during the first year, 100 were associated with a revision and 11 with an occlusion.

In a second analysis of similar nature, grafts that underwent a revision were excluded after this primary event. In this assessment, in which second and third graft revisions were not considered, the interval rate of significant de novo stenosis at 9 and 12 months was $4 \%$ and $3 \%$ respectively, and significant progressive stenoses were 
observed in $2 \%$ and $5 \%$ respectively. The interval rate of event causing de novo stenosis at the 9th and 12 th month interval was $2 \%$ and $1 \%$ respectively (Table II). Of the total of 82 event causing stenoses that were observed in the first year 75 were associated with a revision and 7 with an occlusion. The sharp drop in the interval incidence of event causing de novo stenoses in previously unrevised grafts after 6 months is visualized in Figure 3. During the first year, of all event causing de novo stenoses, $84 \%$ had occurred within 6 months.

Table I. Stenoses occurring in all surveilled grafts, including grafts that were enrolled again after a Ist and a 2 nd revision.

Allgrafts bweek 3 monch 6 month 9 month 12 month

No. surveilled grafts

244

244

238

221

210

Significant graft stenosis

$\begin{array}{lrrrrr}\text { Total } & 41 & 57 & 50 & 40 & 35 \\ \text { De novo }^{2} & 41 & 34 & 23 & 11 & 10 \\ \text { Progressive }^{3} & - & 23 & 27 & 29 & 25\end{array}$

Event causing stenosis ${ }^{4}$

$\begin{array}{lrrrrr}\text { Total } & 20 & 31 & 32 & 12 & 16 \\ \text { De novo } & 20 & 20 & 19 & 8 & 15 \\ \text { Progressive } & - & 11 & 13 & 4 & 1 \\ \text { Recurrent stenosis }^{5} & - & 4 & 5 & 6 & 9\end{array}$

Event causing de nowo stenosis

ino. grafts $(\%)$

8

8

8

4

7

1. Significant stenosis is PSV-ratio $22.5 ; 2$. de mowo stenosis is previous PSV-ratio $<2.0 ; 3$ progressive stenosis is previous PSV-ratio $\geq 2.0$ and increase of PSV-ratio $\geq 1.0 ; 4$. event causing stenosis is graft with revision or occlusion; 5 . recurrent stenosis is revised graft with secondary event causing stenosis. 
Table II. Stenoses occurring in surveilled grafts with follow-up ending after a first revision.

Previously unrevised grafts 6 week 3 month 6 month 9 month 12 month

No. surveilled grafts

244

224

203

169

152

Significant graft stenosis

$\begin{array}{lrrrrr}\text { Total } & 41 & 50 & 39 & 24 & 18 \\ \text { De novo }^{*} & 41 & 31 & 18 & 6 & 5 \\ \text { Progressive sten. }^{3} & - & 9 & 12 & 4 & 7 \\ \text { Stable sten. }^{4} & - & 10 & 9 & 14 & 6\end{array}$

Event causing stenosis ${ }^{5}$

$\begin{array}{lrrrrr}\text { Total } & 20 & 26 & 23 & 6 & 7 \\ \text { De novo } & 20 & 19 & 15 & 4 & 2 \\ \text { Progressive } & - & 7 & 8 & 2 & 5\end{array}$

Ewent causing de novo stenosis

/ no. grafts $\%$

8

8

7

2

1

1. Significant stenosis is PSV-ratio $22.5 ; 2$, de nova stenosis is previous PSV-ratio $<2.0 ; 3$. progressive stenosis is previous PSV-ratio $\geq 2.0$ and increase of PSV-ratio $\geq 1.0 ; 4$. stable stenosis is previous PSVratio $\geq 2.0$ and increase of $P S V$-ratio $<1.0 ; 5$. event causing stenosis is graft with revision or occlusion.

\section{DISCUSSION}

The usefulness of duplex scanning for follow-up of infrainguinal vein grafts has long been recognised, and several comparative studies have demonstrated that duplex scanning is superior to standard follow-up methods for detecting graft stenosis. ${ }^{2,4}$ in Some individual grafts are at greater risk of failure than others. Pactors that were reported to be associated with this higher risk include: critical limb ischemia, diabetes, poor crural run-off, previous arterial reconstruction, composite or spliced vein grafts, non in-situ technique, and minimal graft diameter ${ }^{4.5,10,16}$ In the present study the risk of severe graft stenosis requiring intervention was significantly increased in grafts that had a PSV-ratio $(22.5)$ at the initial duplex examination. It is likely that the development of stenoses in many patients begins at the time of surgery, and if progression is rapid, these lesions are associated with a high failure rate. 
Figure 3. The incidence of event causing de novo stenoses per surveillance interval in previously unrevised grafts during the first postoperative year.

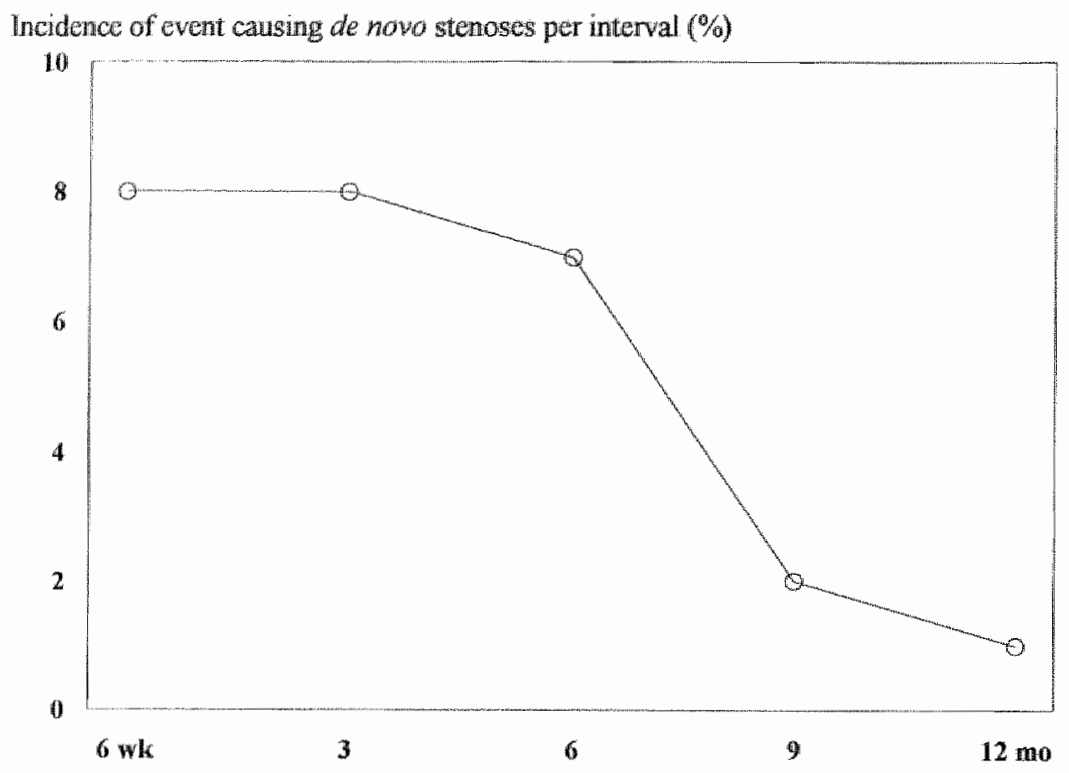

Surveillance period

It has been suggested that the first duplex scanning is best performed at the completion of the operation or before discharge. Unrepaired early duplex abnormalities required later correction in $32 \%$ to $52 \%$. $^{5.8,18}$ It is assumed that residual and minor defects in vein grafts may serve as a nidus for severe graft stenoses to develop later after implantation. It was hypothesized that if early postoperative duplex findings permitted distinction of grafts into low and high-risk groups, a more rational surveillance protocol may be instituted. Mills and coworkers found that $45 \%$ of lesions detected by intraoperative duplex scanning progressed to high-grade stenoses, that either required revision or occluded before an intervention was performed. In their study $23 \%$ of lesions remained stable, and $32 \%$ regressed. ${ }^{6}$ These authors, as well as others suggested that an early separation of grafts into high-risk and low-risk groups was possible, allowing them to focus all surveillance attention to the higher risk group, while subjecting the other grafts to a less intensive or non-surveillance policy. ${ }^{6,8}$ The outcome of the present prospective study supports the observation of these earlier studies, though not necessarily their conclusions. As expected, we found that early severe lesions (PSV-ratio 22.5 ) quite often required a revision. Grafts with "early mild 
to moderate lesions" represented by initial PSV-ratios between 1.5 and 2.5 follow a similar course with regard to primary patency as grafts in patients with completely normal PSV-ratios $(<1.5)$. In addition it appears that patients with nomal grafts by no means are safeguarded for a primary event at later follow-up, as the primary patency at 12 months was $71 \%$. Therefore, excluding initially normal grafts from further surveillanee would have resulted in a less effective surveillance protocol. These observations are supported by other studies, in which it was found that normal early duplex findings did not equate with the long-term absence of graft-threatening lesions. ${ }^{19,20}$ Consequently, all grafts need to be followed from an early stage. At present we perform a full predischarge duplex scan in all patients. Whether this will improve on the information obtained by a 6-week scan as the initial examination, requires further evaluation. It is known that approximately one-third of early identified stenoses regress ${ }^{6}$ negating the usefulness of their detection in the first postoperative week. The favorable overall outcome of revising identified severely stenotic lesions, which has been reported in many previous studies, ${ }^{2,7,17,19}$ was confirmed in the present study. The secondary patency rate in the category with PSV-ratios $>3.0$ was $80 \%$, which may be considered a satisfactory result.

Taylor et al. were among the first to propose in 1990 a rationalized surveillance program by limiting the duration. ${ }^{9}$ In their study all stenoses were detected in the first year after operation and none occurred after this time. It was recognized that grafts will continue to fail in subsequent years, but this was at an annual rate of only $2 \%$ to $3 \%$, which did not justify the cost involved with continuing surveillance of all grafts. At the present time many authors agree that routine graft surveillance is not indicated after 12 months of follow-up. ${ }^{4,9,21}$ Erickson et al. in a recent analysis kept an opposite view. ${ }^{13}$ They observed that of 236 grafts that developed surveillance abnormalities 21 had their initial defect more than 2 years after the initial bypass procedure. However, in this series, stenoses in the vein itself developed after a median follow-up period of 6 to 8.5 months, whereas inflow and run-off lesions developed after a median follow-up of 15 and 29 months, respectively. This difference in the time of onset of lesions in the vein conduit and in the arteries was explained by the different nature of the Iesions, with slower progressing atherosclerosis being the dominant factor in the inflow and run-off segments.

Grafting technique is suggested to make a difference for the time of onset of stenoses. In a series, exclusively consisting of in situ bypasses only 2 of 117 grafts needed a revision after 6 months of follow-up. ${ }^{22}$ Unfortunately not many series will exclusively consist of in situ bypasses, as this type of bypass requires a greater saphenous vein with a good caliber throughout its entire length. We found that grafts with treated stenoses are at increased risk of developing a recurrent stenosis or a second stenosis at another location. After revision a venous bypass should be followed by regular duplex examination for at least another 6 months as a recurrence can be 
cxpected in about one out of four grafts. ${ }^{9,23,24}$ However, the majority of grafts do not require an intervention within 6 months after operation, and if there is no evidence of a stenosis and the maximum PSV-ratio is less than 2.0 , intensive surveillance can be safely stopped, which was the crucial observation in the present study. Only $2 \%$ of surveilled patients without previous revision at 9 months and in $1 \%$ at 12 months developed an event causing de novo stenosis. Moreover, it has been reported that de novo lesions that develop after 6 months tend to be stable, and infrequently require revision. ${ }^{25,26}$

In conclusion, the typical time course of vein graft failure and intervention appeared to be related to the onset and progression of graft lesions. Our current protocol after discharge includes examinations at 6 weeks, 3 months and 6 months. Thereafter, in the absence of previous revisions or duplex abnormalities, discretionary clinical examinations may be scheduled annually just to check on the return of symptoms. 


\section{REFERENCES}

1. Szilagyi DE, Elliot JP, Hageman JH, Smith RF, Sallolmo CA. Biological fate of autologous vein implants as arterial substitutes. Anm Surg 1973;178-232-246.

2. Grigg MJ, Nicolaides AN, Wolfe JHN. Femorodistal vein bypass graft stenosis. Br J Surg $1988 ; 75: 737-740$.

3. Moody $P$, deCossart LM, Douglas HM, Harris PL. Asymptomatic strictures in femoropopliteal vein grafts. Eur J Vase Surg 1989;3:389-392.

4. Giannoukas AD, Androulakis AE, Labropoulos N, Wolfe IN. The role of surveillance after infrainguinal bypass grafting. Eur J Vasc Endovasc Surg 1996;11:279-282.

5. Gupta AK, Bandyk DF, Cheanwechia D, Johnson B. Natural history of infra-inguinal vein graft stenosis relative to bypass grafting technique. J Vase Surg 1997;25:211-225.

6. Mills JL, Bandyk DF, Gahtan V, Essess GE. The origin of infrainguinal vein graft stenosis: A prospective study based on duplex surveillance. J Vasc Surg 1995;21:16-25.

7. Bandyk DF, Johnson BL, Gupta AK, Essess GE. Nature and managenent of duplex abnormalities encountered during infrainguinal vein bypass grafting. J Vasc Surg 1996;24:430438.

8. Nielsen TG. Natural history of infrainguinal vein bypass stenoses: Early lesions increase the risk of thrombosis. Eur J Vasc Endovasc Surg 1996;12:60-64.

9. Taylor PR, Wolfe JHN, Tyrrell MR, Mansfield AO, Nicolaides AN, Houston RN. Graft stenosis: justification for 1-year surveillance. Br J Surg 1990;77;1 125-1128.

10. Chang BB, Leather RP, Kaufman JL, Kupinsky AM, Leopold PW, Shah DM. Hemodynamic characteristics of failing infrainguinal in situ bypass. J Vasc Surg 1990;12.597-600

11. Sanchez LA, Gupta SK, Veith FJ, Goldsmith J, Lyon RT, Wengerter KR, Panetta TF, Marin $\mathrm{ML}$, Cynamon J, Berdejo. A ten-year experience with one hundred and fifty failing or threatened vein and polytetrafluoroethylene arterial bypass grafts. J Vasc Surg 1991;14:729-738.

12. Dunlop $\mathrm{P}$, Hartshome $T$, Bolia A, Bell PRF, London NJM. The long-term outcome of infrainguinal vein graft surveillance. Eur J Vasc Endovasc Surg 1995;10:352-355.

13. Erickson CA, Towne JT, Seabrook GR, Freischlag JA, Cambria RA. Ongoing vascular laboratory surveillance is essential to maximize long-term in situ saphenous vein bypass patency. J Vasc Surg 1996;23:18-27.

14. Sladen JG, Gilmour JL. Vein graft stenosis: Characteristics and effect of treatment. Am I Surg $1981,41: 549-553$

15. Disselhoff $B$, Buth J, Jakimowicz J. Early detection of stenosis of femorodistal grafts. A surveillance study using color-duplex scanning. Eur J Vase Surg 1989;3:43-48.

16. Blackshear WM, Thide BL, Strandness DE. Natural history of above and below knco femoropopliteal grafts. Am J Surg 1980;140:234-241.

17. Lundell A, Lindblad B, Bergqvist D, Hansen F. Femoropopliteal-crural graft patency is improved by an intensive surveillance program: A prospective andomized study J Vase Surg 1995;21:2634.

18. Wilson YG, Davies $A H$, Currie JC, McGrath $C$, Morgan $M$, Baird RN, Lamont PM. The value of pre-discharge scanning in infrainguinal graft surveillance. Eur $J$ Vasc Endovasc Surg $1996 ; 10237-242$.

19. Bergamini TM, George SM Jr, Massey HT, Henke PK, Klamer TW, Lambert GE, Miller FB, Garrison RN, Richardson JD. Intensive surweillance of femoropoptiteal-tibial autogenous vein bypasses improves long-term graft patency and limb salvage. Ann Surg 1995; 221:507-516. 
20. Passman MA, Moneta GL, Nehler MR, Taylor LM Jr, Edwards M. Yeager RA, Me Connel $\mathrm{DB}$, Porter JM. Do normal carly color-flow duplex survellance examination results of infrainguinal vein grafts preclude the need for late graft revision. J Wasc Surg 1995;22:476-484.

21. Green RM, McNamarra J, Ouriel $K$, DeWeese IA. Comparison of infrainguinal graft surveillance techniques. J Vase Surg 1990;11:207-215.

22. Mohan CR, Hoballah JJ, Schueppert MT, Sharp WJ, Kresowilk. TF, Miller EV, Corson JD. Should all in situ saphenous vein bypasses undergo permanent duplex surveillance? Arch Surg $1995 ; 130: 483-488$.

23. Berkowitz $\mathrm{HD}$, Greenstein S, Barker CF, Perloff LJ. Late failure of reversed wein bypass grafts. Ann Surg 1989;210:782-786.

24. Leopold PW, Shandal AA, Kay C. Duplex ultrasound: its role in the non-invasive follow-up of the in situ saphenous vein bypass. J Vase Technol 1987;11:183-186.

25. Ho GH, Moll FL, Kuipers MM, van de Pavoordt EDWM, Algra A Long-term surveillance by duplex scanning of unrevised infragenicular graft stenosis. Ann Vasc Surg 1995;9:547-553.

26. Caps MR, Cantwell-Grab K, Bergelin RO, Strandness DE. Vein graft lesions: Time of onset and ratic of progression. J Vasc Surg 1995;22:466-475. 
Chapter 8

\section{General Discussion}




\section{GENERAL DISCUSSION}

This thesis describes the experience with color-flow duplex surveillance of autologous vein grafts to detect vein graft stenosis.

In the retrospective part (chapter 3 ) the results of a study, published in 1993, are presented. In this study standardized methods for duplex surveillance were used throughout the study period, allowing valid conclusion on parameters and criteria for the diagnosis of critical vein graft stenosis. It demonstrated that durable long-term improvement in patency rates of up to $19 \%$ can be achieved by the implementation of a systematic program of color-flow duplex surveillance and selective secondary intervention in critical lesions. A large number of studies have demonstrated the beneficial effect of graft surveillance on patency. ${ }^{1-4}$

In the prospective part of the thesis the results are presented of a study which was supported by a Grant from the Commission of Investigative Medicine of the Dutch National Health Insurance Council. This study started in 1993 and was performed in three hospitals (Catharina Hospital Eindhoven, Academic Hospital Maastricht, and St. Antonius Hospital Nieuwegein). The protocol defined a number of questions that need to be addressed and the analysis of these questions form the basis of the prospective part of this thesis.

The first question was the influence of patient and graft factors on the development of vein graft stenoses and their significance for clinical management (chapter 4). Of all the different factors tested the minimal graft diameter was the only significant factor that had a significant correlation with the occurrence of graft stenosis. Although the minimal graft diameter is a predictor of graft lesion development, the specificity is still too low to deny vein graft surveillance to patients with grafts greater than $4.5 \mathrm{~mm}$. In grafts with a minimal diameter of greater than $4.5 \mathrm{~mm} 25 \%$ had developed a significant graft stenosis at one year after the operation. In the present series factors representing the general vascular status of the patient (indication for operation, presence of diabetes mellitus, of coronary artery disease, of hypertension, etc) did not have a significant correlation with the development of vein graft stenoses. In contrast, a local graft factor such as the minimal graft diameter had a strong correlation with vein graft stenosis development and this observation supports the view that vein graft stenoses may be caused by local graft-related factors. These factors may consist of pre-existing vein pathology and intraoperative microlesions of the conduit. There is increasing data that the quality of the graft immediately after implantation may be the most important factor for durable vein graft function. ${ }^{5,6}$

The second question related to the diagnostic accuracy of the several investigated surveillance parameters to detect vein graft stenoses (chapter 5). The accuracy was assessed with angiography as the gold standard. All investigated duplex and ankle 
brachial pressure-derived parameters, except for the volume flow, had a significant difference at univariate analysis for the group with DSA confirmed lesions $770 \%$, and the group with $\geq 70 \%$ DR. Using multivariate analysis the PSV-ratio and the ankle blood pressure (ABP) appeared independent predictors of stenoses of $>70 \%$, overtoning all other parameters. The combination of these two variables, however, provided hardly a better sensitivity and specificity to identify graft stenosis $>70 \%$ than the PSV-ratio alone. A PSV-ratio $\geq 3.0$ was a reasonable indicator of the presence of a stenosis $\geq 70 \%$ with a sensitivity of $80 \%$ and a specificity of $84 \%$. These observed results are in agreement with those reported by other authors. ${ }^{7-9}$

The third question was: Is vein graft stenosis revision without angiography justified and what criteria should be used (chapter 6). Replacing angiographic evaluation of vein graft stenoses prior to revision by duplex scanning would be advantageous. It would result in less delay of the revisional procedure and it would also reduce the overall costs of graft surveillance programs. On the basis of the PSVratio a two-parameter algorithm is presented which has the best combination of efficiency (limitation of the number unnecessary revisions), safety (minimal number of correctable lesions missed) and reduction of angiograms. This algorithm included a PSV-ratio $<2.5$ to delineate patients in which a conservative approach without angiography or revision was appropriate, a PSV-ratio $>4.0$ to indicate patients in which vein graft revision without angiography could be scheduled, and a group with PSV-ratios between 2.5 and 4.0 in which an angiogram was to be performed to determine clinical management on the basis of the stenosis severity. In addition it resulted in a reduction of the number of angiograms of $49 \%$ compared with a policy of angiographies in all patients with a PSV-ratio $>2.5$. There are recent studies in which a revision is performed solely on the basis of the PSV-ratio. ${ }^{9,10}$ In the future we will probably use the PSV-ratio as the intervention criterium and not the angiographic degree of stenosis. Replacing prerevisional angiography with duplex parameters is an important issue and needs to be studied in the future.

The fourth question was: Are their ways to limit the graft surveillance program, in other words how can graft surveillance programs be economized (chapter 7). Two strategies were examined. The first strategy to investigate this question was to assess the predictive role of the first postoperative duplex scan for any subsequent vein graft stenosis development. Some reports have described that the majority of vein graft stenoses may develop soon after the operation. ${ }^{11.12}$ Therefore we examined whether the initial duplex scan can be used as a criterion to categorize grafts into a high and a lowrisk category for the development of a vein graft stenosis. Although subgroups of grafts with initial PSV-ratios demonstrated statistical correlation with later vein graft stenosis development, it appeared that patients with "normal grafts" (initial PSV-ratio $<1.5$ ) are by no means safeguarded for a primary event at later follow-up, as the primary patency at 12 months is $71 \%$. Excluding normal grafts from further surveillance would 
obviously have resulted in a less effective surveillance protocol. These observations are supported by other studies, in which it was found that normal early duplex findings did not equate with the long-term absence of graft-threatening lesions. . $^{10,13}$ Consequently all grafts need to be followed from an early stage.

In the second strategy the possibility to limit the duration of duplex surveillance was investigated. It appeared that $84 \%$ of all "event causing de novo stenoses" had occurred before six months. The majority of grafts that did require an intervention after six months postoperatively had previous evidence of a stenosis with a PSV-ratio $\geq 2.0$. In grafts that were normal at 6 months surveillance, usually no stenoses developed at a later time. Only in $2 \%$ of surveilled patients without previous revision at 9 months and in $1 \%$ at 12 months a de novo stenosis was identified. Moreover, it was reported that de novo lesions that develop after 6 months tend to be stable, and infrequently require a revision. These findings are in accordance with those of other authors. ${ }^{11,14-16}$ On the basis of these observation it is recommended that surveillance is stopped if vein grafts are found normal at 6 months and did not require a revision in the first half year. 


\section{REFERENCES}

1. Berkowitz HD, Greenstein SM. Improwed patency in reversed femoral-infrapopliteal autogeous vein grafts by early detection and treatment of the failing graft. IVasc Surg 1987;5; 755-761

2. Bandijk DF, Schmitt DD, Seabrook GR, Adans MB, Towne JB. Monitoring functional patency of in-situ saphenous wein bypasses: The impact of a surweillance protocol and elective revision. I Vasc Surg 1989;9:286-296.

3. Moody P, Gould DA, Harris PL. Vein graft survelllance improves patency in femoro-poplitcal bypass. Eur J Vasc Surg 1990;4:117-121.

4. Lundell A, Lindblad B, Bergqvist D, Hansen $\mathbb{F}$. Femoropopliteal-crural graft patency is improved by an intensive surveillance program: A prospective randomized study. I Vase Surg 1995;21:2634.

5. Varty K, London NJM, Brennan JA, Ratliff DA, Bell PRF. Infragenicular in situ vein bypass graft occlusion: A multivariate risk factor analysis. Eur J Vasc Surg 1993;7:567-571.

6. Belkin M, Raftery KB, Mackey WC, McLaughlin RL, Unphrey SE, Kunkemueller A, O'Donnell TF. A prospective study of the determinants of vein graft flow velocity; Implications for graft surveillance. J Vasc Surg 1994;19:259-267.

7. Dalsing MC, Cikrit DF, Lalka SG, Sawchuk AP, Schulz C. Femorodistal vein grafts: Tho utility of graft surveillance criteria. J Vasc Surg 1995;21:127-134.

8. Taylor PR, Tyrrell MR, Crofton M, Bassan B, Grigg M, Wolfe JHIN, Mansfield AO, Nicolaides AN. Colour flow imaging in the detection of femoro-distal graft and native artery stenosis: Improved criteria. Eur J Vasc Surg 1992;6:232-236.

9. Belkin M, Schwartz LB, Donaldson MC, Mannick JA, Whittemore AD. Hemodynamic impact of vein graft stenoses and their prediction in the vascular laboratory. J Vasc Surg 1997;25:10161022 .

10. Gupta AK, Bandijk DF, Cheanvechai D, Johnson BJ. Natural history of infrainguinal wein graft stenosis relative to bypass grafting technique. J Vasc Surg 1997;25:211-225.

11. Caps MT, Cantwell-Gab K, Bergelin RO, Strandness DE. Vein-graft lesions: Time onset and rate of progression. J Vasc Surg 1995;22:466-475.

12. Mills JL, Bandijk DF, Gahtan V, Esses GE. The origin of infrainguinal wein graft stenosis: A prospectiwe study based on duplex surveillance. J Vase Surg 1995;21:16-25.

13. Passman MA, Moneta GL, Nehler MR, Taylor LM Jr, Edwards JM, Ycager RA, Mc Connel DB, Porter JM. Do normal early color-flow duplex surveillance cxamination results of infrainguinal vein grafts preclude the need for late graft revision? J Vasc Surg 1995;22:476-484.

14. Taylor PR, Wolfe JHN, Tyrrell MR. Mansfield AO, Nicolaides AN, Houston RN Graft stenosis: Justification for 1-year' surveillance. Br J Surg 1990;77: I 125-1 1|28.

15. Ho GG, Moll FL, Kuipers MM, van de Pavoordt EDWM, Algra A. Long-term survellanco by duplex scanning of non-reversed infragenicular graft stenosis. Ann Vase Surg 1995,9:547-553.

16. Mohan CR, Hoballah JJ, Schucppert MT, Sharp WJ, Kresowik TFF, Miller EV, Corson JD. Should all in situ saphenous wein bypasses undergo permanent duplex scanning? Arch Surg $1995 ; 130: 483-488$. 
Chapter 9

\section{Summary}

\&

\section{Samenvatting}




\section{SUMMARY}

Definiom: Surveillance of infrainguinal autologous wein bypasses is a structured schedule for use of diagnostic methods to detect stenoses in these grafts or adjacent to the bypasses. Early repair of graft stenoses may prevent graft thrombosis.

Chaprer one is the preface of the study. It describes how graft surveillance had started. It gives an outline of the design of the retrospective and of the prospective studies. In addition, the questions that were investigated in the prospective part of the study (aims of the study) are formulated.

Chapter two contains a review of the literature on various aspects of postoperative infrainguinal graft surveillance.

Chapter three focussed on the contribution of color-flow duplex surveillance to improve infrainguinal autologous vein graft patency in two patient groups. Patency rates were compared between a group followed by color-flow surveillance group and a group that were subjected to clinical follow-up only. The assisted primary graft patency rates was improved by $19 \%$ with the use of a color-flow duplex surveillance and repair of detected significant stenotic lesions.

Chapter four discussed the influence of various clinical and graft factors on the development of stenotic lesions in infrainguinal autologous vein bypasses, and to investigate wether this may lead to modifications to rationalise duplex surveillance programs or surgical techniques of these bypass procedures. The minimal graft diameter appeared to be the only significant factor that correlated with the development of a vein graft stenosis during follow-up. Several other systemic factors, previously documented to be associated with infrainguinal autologous vein graft failure or stenoses development, failed to show any correlation. "The 1-year secondary patency rate of composite vein and arm-vein grafts with a minimal diameter $\geq 3.5 \mathrm{~mm}$ was significantly better than that of single greater saphenous grafts with a minimal graft diameter $<3.5 \mathrm{~mm}(94 \%$ and $76 \%$ respectiveley, $p=0.03)$. Although the minimal graft diameter is an important risk factor for stenoses development in infrainguinal autologous vein bypasses, it was not practical for use in tailoring duplex surveillance programs with respect to the risk of failure. However it may have significance in guiding the surgeon to make use more often of composite vein and arm-vein grafts.

Chapter five assessed the diagnostic accuracy of a number of surveillance parameters, all previously described in the literature, to detect stenoses in infrainguinal autologous vein bypasses. Surveillance parameters were compared with angiography as the gold 
standard. Except for volume flow-related variables all other variables showed significant differences at univariate analysis between angiographic stenosis $<70 \%$ and $\geq 70 \%$ diameter reduction. Using a logistic regression analysis it was found that the PSV-ratio was the best parameter to grade vein graft stenosis by non-invasive examination. A PSV-ratio with a cutoff value of 3.0 had the best sensitivity and specificity to detect a stenosis with an $\geq 70 \%$ angiographic diameter reduction. Other surveillance parameters than the PSV-ratio had lower sensitivities and specificities and were not usefull in clinical practice.

Chapter six investigated wether revision of stenoses in infrainguinal autologous vein bypasses without angiography was justified and what criteria should be used. From the investigation described in chapter five of this thesis, it appeared that the PSV-ratio was the best indicator of a high-grade vein graft stenosis. Therefore a series of cutoff values of this parameter were correlated with the occurrence of primary clinical events by cumulative hazard analysis with transient state method and Kaplan-Meier graphs. It appeared that for clinical application an algorithm based on a single surveillance parameter (single PSV-ratio cut-off value) to differentiate between intervention and non-intervention was not sufficiently accurate to replace prerevision angiography. It was demonstrated that the best combination of efficacy (limitation of the number of unnecessary revisions), safety (minimal number of correctable lesions missed) and reduction of angiograms was obtained by a two-parameter surveillance algorithm. This algorithm included a PSV-ratio $<2.5$ to delineate patients in which a conservative approach without angiography or revision was appropriate, a PSV-ratio $>4.0$ to indicate patients in which vein graft revision without angiography could be scheduled, and a group with PSV-ratios between 2.5 and 4.0 in which an angiogram was to be performed to determine clinical management on the basis of the stenosis severity. This algorithm had a positive predictive value (PPV) of $93 \%$ and a negative predictive value (NPV) of $89 \%$. In addition it resulted in a reduction of the number of angiograms of $49 \%$ compared with a policy of angiographies in all patients with a PSV-ratio $\geq 2.5$.

Chapter seven investigated two different strategies to reduce the need for frequent duplex scanning of infrainguinal autologous vein grafts.

In the first strategy it was attempted to reduce the number of patients for continued surveillance by identifying grafts with a possible higher risk of significant stenosis development, indicated by the presence of early duplex abnormalities. The presence of moderate abnormalities at the initial duplex scan did not identify patients with a highrisk of an event, as initial PSV-ratios of 1.5 to 2.0 and 2.0 to 2.5 (early mild-moderate lesions) had comparable 12-month primary patencies as patients with a PSV-ratio $<1.5$ (completely normal grafts): $(63 \%, 73 \%$, and $71 \%$ respectively). Considered the fact that grafts with a initial PSV-ratio $<1.5$ was associated with a fairly high incidence of 
primary events ( 12 month primary patency $71 \%$ ) it was concluded that initially normal grafts may develop stenotic lesions sometime after the procedure. Therefore, it is not justify to withold a regular surveillance program to initially normal infrainguinal autologous vein bypasses.

In the second strategy the effects of reducing the duration of the surveillance program per patient was examined. The interval incidence of "event causing de novo stenoses" was $8 \%$ of the total number of duplex tests performed at 3 months, and also $8 \%$ at 6 months after the operation. In patients that had no previous intervention for stenosis a sharp drop in this incidence was seen at 9 and 12 months, with "event causing de novo stenoses" in only $2 \%$ and $1 \%$ of all duplex tests. The duration of the surveillance period may be restricted to the first six months after operation in patients that have a normal infrainguinal autologous vein bypass during that time period, as only few vein graft stenoses will be missed by this policy.

Chapter eight provides the general discussion. 


\section{SAMENVATTING}

Definitie: Surveillance van infrainguinale autologe veneuze bypasses is een gestructureerd programma voor gebruik van diagnostische methoden voor het detecteren van stenosen in deze bypasses of in hun naburige arterielle segmenten. Tijdige correctie van deze stenosen kan bypass trombose voorkomen.

Hoofdstuk 1 was het voorwoord van de studie. De gedachten achter de start van venebypass surveillance, de retrospectieve studie en de opzet van de prospectieve studie werden besproken. Ook werden de vragen die onderzocht werden in het prospectieve deel van de studie (doelstellingen van de studie) geformuleerd.

In hoofdstuk 2 werd er een literatuur overzicht gegeven over de verschillende aspecten van postoperatieve infrainguinale bypass surveillance.

Hoofdsmk 3 evalueerde het effect van een kleuren duplex surveillance programma op de verbetering van de patency van infrainguinale autologe veneuze bypasses. De patencies van deze bypasses werden vergeleken tussen een groep patiënten die met een kleuren duplex scanner werden vervolgd en patiënten die alleen met klinischonderzoek gecontroleerd werden. Het bleek dat de geassisteerde primaire patency van de infrainguinale autologe veneuze bypasses verbeterd werd met $19 \%$ door gebruik te maken van een kleuren duplex surveillance programma en herstel van gevonden sigmificante stenotische afwijkingen.

Hoofdstuk 4 handelde over de invloed van verschillende patiënt- en bypass faktoren op de ontwikkeling van stenosen in infrainguinale autologe veneuze bypasses en de eventuele aanpassing van het surveillance programma of chirurgische technieken van deze bypass procedures. De gemeten minimale bypass diameter bleek de enigste factor te zijn die significant gecorreleerd was met het ontstaan van stenosen in deze bypasses gedurende follow-up. Verschillende andere systemische faktoren, die voorheen werden beschreven als gerelateerd met bypass occlusie of stenose vorming, bleken niet gecorreleerd te zijn met stenose vorming. De 1-jaars secundaire patency van samengestelde veneuze en arm-vene bypasses met een minimale bypass diameter $>3.5$ mm was significant beter dan die van een complete vena saphena magna bypass met een minimale diameter $<3.5 \mathrm{~mm}(9.4 \%$ en $76 \%$ respectievelijk, $p=0,03)$. Alhoewel de minimale bypass diameter een belangerijke risico faktor is voor stenose ontwikkeling in infrainguinale autologe veneuze bypasses, is het praktisch niet mogelijk het duplex surveillance schema op basis hiervan aan te passen. Maar het kan wel zódanig gebruikt worden waardoor de chirurg vaker samengestelde vene bypasses en arm-vene bypasses kan gebruiken. 
Hoofoluk 5 beschreef de diagnostische accuratheid van verscheidene surveillance paratneters om stenosen in infrainguinale autologe veneuze bypasses te detecteren. De surveillance parameters werden vergeleken met de angiografie als gouden standaard. Behoudens de volume flow gerelateerde parameters toonden alle andere parameters een significant verschil bij een univariate analyse tussen een angiografische stenose van $<70 \%$ en $\geq 70 \%$ diameterreductie. Een logistische regressie analyse toonde aan dat de PSV-ratio de beste parameter is om stenosen in infrainguinale autologe veneuze bypasses non-invasief te graderen. Een PSV-ratio van 3.0 is het criterium met de beste sensitiviteit en specificiteit om stenosen van $\geq 70 \%$ angiografische diameterreductie te detecteren. Andere surveillance parameters dan de PSV-ratio hebben een lage sensitiviteit en specificiteit en zijn daarom niet bruikbaar in de praktijk.

In hoofdstuk 6 werd onderzocht of revisie van stenosen in infrainguinale autologe veneuze bypasses zonder angiografie gerechtvaardigd was en welke criteria daarbij dienen te worden gebruikt. Uit de onderzoekingen beschreven in hoofdstuk 5 van dit proefschrift bleek dat de PSV-ratio de beste indicator was voor een hoog-gradige veneuze bypass stenose. Er werden verschillende drempelwaarden van de PSV-ratio gecorreleerd met het optreden van primaire klinische gebeurtenissen door middel van cumulatieve risico analyse met "transient state" methoden en Kaplan-Meier curves. Het bleek dat voor klinisch gebruik een algoritme gebaseerd op één surveillance parameter (én enkele PSV-ratio drempelwaarde) om te onderscheiden tussen wel of geen interventie niet accuraat genoeg bleek te zijn om een pre-revisie angiografie te vervangen. Er werd aangetoond dat de beste combinatie wan efficièntie (limiteren van het aantal onnodige revisies), veiligheid (minimaal aantal gemiste comigeerbare laesies) en reductie van het aantal angiogrammen bereikt werd door een tweeparameter surveillance algoritme. Dit algorithme bestaat uit een PSV-ratio $<2.5 \mathrm{om}$ patiènten te classificeren bij wie een conservatief beleid zonder angiografie of revisie juist is, een PSV-ratio $\geq 4.0$ om patiënten te identificeren bij wie een bypass revisie zonder angiografie gepland kan worden en een groep met PSV-ratios tussen 2.5 en 4.0 waarbij een angiografie verricht zal moeten worden om een klinisch besluit te kunnen nemen op basis van de stenosegraad. Dit algoritme had een positieve voorspellende waarde van $93 \%$ en een negatieve voorspellende waarde van $89 \%$. Tevens resulteerde dit in een reductie van $49 \%$ in de antallen verrichte angiogrammen vergeleken met een beleid waarbij alle patiënten met een PSV-ratio $>2.5$ een angiografie zouden ondergaan.

In hoofdstuk 7 werden twee verschillende strategieën onderzocht om de noodzaak tot herhaaldelijk duplex onderzoekingen van infrainguinale autologe veneuze bypasses te reduceren. 
Bij de eerste strategie werd geprobeerd het aantal patiënten die voortdurende surveillance ondergaan te reduceren door identificatie van bypasses die een hoog risico hadden voor een significante stenose, aangegeven door de aanwezigheid van vroege duplex afwijkingen. De aanwezigheid van matige afwijkingen bij de initiële duplex scan identificeerde geen patiënten met een hoog risico voor een gebeurtenis, omdat patiënten met een initiële PSV-ratio van 1.5-2.0 en 2.0-2.5 (matige lesies) vergelijkbare 12-maands primaire patencies hadden als die met een initiele PSV-ratio van $<1.5$ (volledig normale bypasses): ( $63 \%, 73 \%$ en $71 \%$ respectievelijk). Gezien het feit dat infrainguinale autologe veneuze bypasses met een initiële PSV-ratio van $<1.5$ geassocieerd waren met een tamelijk hoge incidentie van primaire bypass gebeurtenissen (occlusie of revisie van een stenose) in het eerste postoperatieve jaar (12-maands primaire patency van $71 \%$ ), werd geconcludeerd dat ook initieel normale bypasses niet gevrijwaard zijn van de ontwikkeling van stenotische afwijkingen. Daarom is het niet gerechtvaardigd om initieel normale infrainguinale autologe veneuze bypasses een regulier duplex surveillance programma te onthouden.

Bij de tweede strategie werd onderzoek verricht naar het effect van reductie van de duur van het surveillance programma per patiënt. De interval incidentic van "gebeurtenis veroorzakende de novo stenosen" was $8 \%$ van het totaal aantal duplex onderzoekingen verricht bij 3 maanden en eveneens $8 \%$ bij 6 maanden na de operatie. Bij patiënten die geen eerdere interventie ondergingen, werd er een scherpe daling van de incidentie gezien bij 9 en 12 maanden, waarbij "gebeurtenis veroorzakende de novo stenosen" in slechts $2 \%$ en $1 \%$ van alle duplex onderzoekingen werden geïdentificeerd. De duur van de surveillance periode kan dus beperkt worden tot de eerste 6 maanden na de operatie bij patiènten die een normale infrainguinale autologe veneuze bypass hadden gedurende deze periode, aangezien bij dit beleid maar sporadisch een bypass stenose gemist zal worden.

Hoofdstuk 8 gaf de algemene discussie. 


\section{DANKWOORD}

Op de afdeling Algemene Heelkunde van het Catharina Ziekenhuis te Eindhoven, zijn de studies zoals beschreven in dit proefschrift geïnitialiseerd. De studies zijn uitgevoerd in nauwe samenwerking met de afdelingen Algemene Heelkunde van het Academisch Ziekenhuis te Maastricht en het St. Antonius Ziekenhuis te Nieuwegein. Aan het tot stand komen van dit proefschrift hebben vele mensen bijgedragen:

Dr. J. Buth, mijn co-promotor. Hij leerde mij de methoden voor het verrichten van klinisch-wetenschappelijk onderzoek en heeft een essentiële bijdrage geleverd aan het tot stand komen van dit proefschrift. Ik ben hem dankbaar voor alle hulp, adviezen en ondersteuning die hij mij de afgelopen jaren heeft gegeven.

Prof. Dr. P.J.E.H.M. Kitslaar, mijn promotor. Zijn vertrouwen in het onderzoek en zijn hulp hebben mij de gelegenheid geboden te kunnen promoveren. Mijn dank voor zijn begeleiding.

Dr J.M.H. Tordoir en Dr. E.D.W.M. van de Pavoordt. Zij includeerden de patiënten uit het Academisch Ziekenhuis Maastricht en het St. Antonius Ziekenhuis te Nieuwegein. Mijn dank voor hun inzet en samenwerking.

Marijke Kolster, de study-nurse. Door het inwoeren van de data heeft zij een grote bijdrage geleverd aan dit onderzoek. Ondanks de aanzienlijke, soms onoverzichtelijke, hoeveelheid data heeft zij dat steeds op een consciëntieuze manier gedaan. Ik dank haar voor de verrichtte inspanningen.

Het secretariaat van de afdelingen Algemene Heelkunde van het Catharina Ziekenhuis te Eindhoven, het Academisch Ziekenhuis Maastricht en het St.Antonius Ziekenhuis te Nieuwegein dank ik voor het frequent opzoeken van de medische dossiers.

Elly Rietjens en collega's van het vaatlaboratorium van het Catharina Ziekenhuis. Mijn dank voor de nauwkeurige wijze waarop zij de bijna duizend duplex onderzoeken voor deze studie hebben verricht.

De vaatlaboranten wan het Academisch Ziekenhuis Maastricht en het St. Antonius Ziekenhuis te Nieuwegein dank ik voor de onderzoeken die zij hebben verricht in het kader van deze studie.

Dr. Ir. W.J. Hop. Ik dank hem voor zijn statistische ondersteuning die van groot belang is geweeest bij de eindanalyse van het onderzoek en het tot stand komen van dit proefschrift.

De chirurgen van het Catharina Ziekenhuis te Eindhoven: Dr. J. Buth, Dr. J.M.M.P.H. Herman, Dr J.J. Jakimowicz, Dr. J.G. Prins, en Dr. H.J.T. Rutten. Zij hebben mij de mogelijkheid geboden dit onderzoek te kumen doen naast mijn klinische werkzaamheden. Tevens ben ik hen erkentelijk voor hun bijdrage aan mijn chirurgische opleiding. 
Last but not least wil ik mijn echtgenoot Shantie bedanken voor de ondersteuning en inzet die zij op vele fronten in de afgelopen jaren heeft geleverd. Ook zij zal samen met onze dochter Danisha blij zijn als dit is afgerond 


\section{CURRICULUM VITAE}

26 juli 1964 Geboren te Paramaribo, Suriname.

1982 Atheneum-B aan de Algemene Middelbare School (AMS) te Paramaribo.

1989 Arts-examen aan de Erasmus Universiteit te Rotterdam.

1990 - 1992 Arts-assistent niet in opleiding, afdeling Algemene Heelkunde, Catharina Ziekenhuis te Eindhoven (Hoofd: Dr. J.G. Prins).

1993 - 1997 Arts-assistent in opleiding tot chirurg, Catharina Ziekenhuis te Eindhoven (Opleider: Dr. J.G. Prins, opgevolgd door Dr. J.J. Jakimowicz).

1997 - heden. Arts-assistent in opleiding tot chirurg, Academisch Ziekenhuis Maastricht (Opleider: Prof. Dr. G. Kootstra). 
Het werschingen van dit prosfschrift werd mede mogelijk gemaakt door de funanciele ondersteuning van

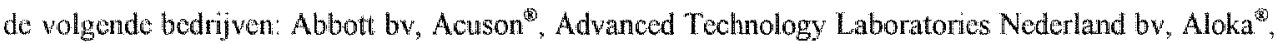
Asta Medica bv, Bard Benelux nw, Bauerfeind Benelux bv, Boston Scientific Coorporation, Convatec Gambro bv, W.L Gore \& Associates bv, Hewlett-Packard Nederland bw, Karl Storz Endoscopie, Mathys Medical Nederland bv, Schering Nederland bv, Sigma Medical bv en Stöpler Instrumenten bv. 

Het verschijnen van dit proefschrift werd mede mogelijk genaakt door de financiële ondersteuning wan

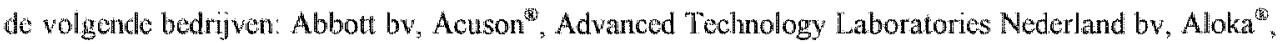
Asta Medica bv, Bard Benelux nv, Bauerfeind Benelux bv, Boston Scientific Coorporation, Convatec Gambro bv, W.L Gore \& Associates bw, Hewlett-Packard Nederland bw, Karl Storz Endoscopie, Mathys Medical Nederland bv, Schering Nederland bv, Sigma Medical bv en Stöpler Instrumenten bv. 